(11) Nordregio

\title{
Regional Tourism Satellite Accounts for the Nordic Countries
}

Anna Karlsdóttir and Nora Sánchez Gassen

NORDREGIO REPORT 2021:2

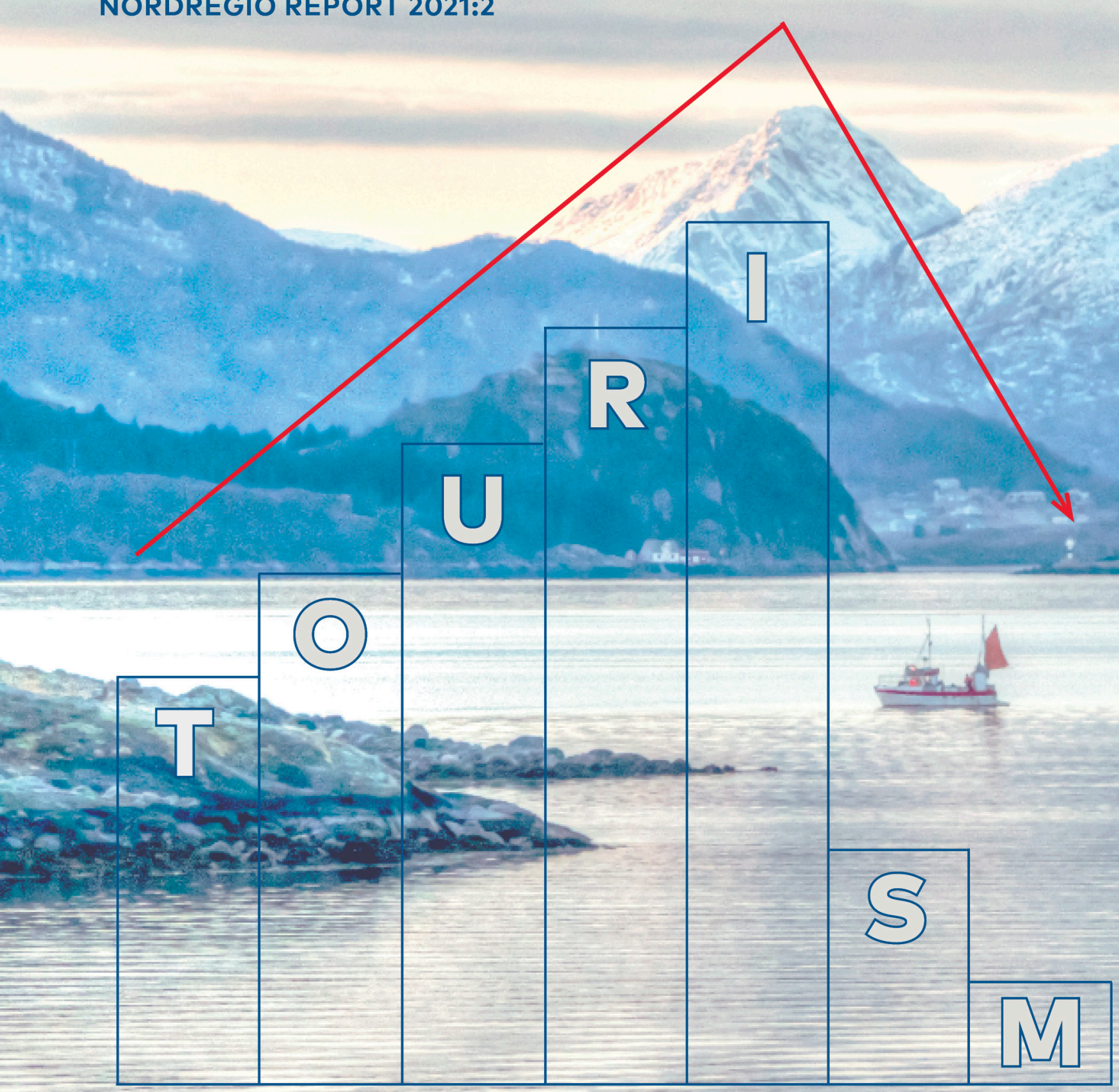


Preface

Summary $\quad 5$

$\begin{array}{ll}\text { Sammenfatning } & 6\end{array}$

1. Tourism in recent decades-growth and the $\quad 7$ economy

2. The importance of developing regional tourism 9 satellite accounts

3. The history and role of tourism satellite account development

3.1 Opportunities and challenges in economic measurement using tourism satellite accounts

3.2 Constructing regional tourism satellite accounts

4. Guidelines and manuals for developing TSAs from major international organizations

5. Nordic regional tourism satellite accounts-description and main tables by country

5.1 Denmark

5.2 Finland

5.3 Iceland

5.4 Norway

27

5.5 Sweden

28

5.6 Faroe Islands

30

5.7 Greenland

5.8 Åland

6. Expert statements on TSAs-advantages and disadvantages

6.1 Common Regional TSA accounting analysis and method for the Nordic countries

6.2 Possible next steps in developing RTSAs in the Nordic 
6.3 Steps for developing a Nordic RTSA

6.4 Comparable or independent RTSAs in the Nordic countries?

38

References

40

Appendix

45

Appendix I

45

Appendix II

47

Denmark

47

Finland

53

Iceland

60

Norway

69

Greenland

73

Åland

74

About this publication

76 


\section{Preface}

Once upon a time, the Nordic Council of Ministers stipulated a Nordic Method Model to assess the regional economic impacts of tourism in the Nordic countries. The 1970s to early 1980 s was an era when affluent summer guests drawn by pictures of desirable locations began buying houses in rural areas. These were often affiliated with nature-based amenities in the vicinity (such as the sea, forests or mountains). When this development caused housing prices to rise, debate arose over rural-urban mobility, tourism patterns and their economic impacts (Kolbe \& Gustavsson, 2018). For example, in Sweden, the rural population sensed a shift in values related to residential areas, but were critical of what these changes in values would entail (ibid, p.41). From the perspective of the summer guests, they believed that they contributed to the economy by providing a customer base for services provided by coastal communities.

Moreover, at around the same time, Nordic citizens had more opportunities to travel to sunny locations. For example, Danish tourism to Spain took off, enabled by technology and scheduled direct charter flights. Instead of traveling for days by bus back and forth, sunny destinations could now be reached in few hours. The sublime mountainscapes of Norway became a magnet, as did more remote attractions such as Cape North, and the range of rural tourism products widened over time (Müller, 2013). In the first and second decade of this century, tourism has grown steadily, albeit with regional variation, but in many cases, it has become an established sector of Nordic economies in terms of both employment and revenue.

While the Nordic model of regional economic impacts reflects its time, this urban-rural, domestic inbound-outbound mobility dynamic has always been associated with the economics of tourism. Prior to 2000, the two most common methods used to understand the impact of tourism, the Nordic Model and the input-output method, were advocated because they linked supply and demand and focused on the money flow from tourists to tourism enterprises, including circulation within the tourism supply sector. However, these methodologies were subject to criticism, as they gave little consideration to the contribution of local factors to the volume and quality of tourism (Paajanen, 1997). Tourism satellite accounts (TSAs), with their conceptual framework and manual, gradually became the internationally acknowledged approach to understanding the economic impact of tourism (United Nations Statistical Office, 2010; Frechtling \& Smeral, 2010).

1. "Sommargästerna åt sin sida framhöll att de bidrog till kustorternas bästa genom att de gav ett bättre kundunderlag åt affärarerna vid kusten" (DN 7.October, 1978). 


\section{Summary}

Tourism has played a growing role in the last two decades in the economic development of many Nordic countries until the Covid-19 pandemic hit and the tourism sector suffered from the effects of reduced travel desire and restrictions. After relief, tourist influx will resurrect and again affect local economies around the Nordic region. Tourism has economic effects.

When people travel, they pay for goods and / or services such as accommodation, food, souvenirs and activities. They may be shopping in preparation for their trip or as part of their return trip. Before, during and after the trip, their expenses are directly related to the tourism activity which generates profits, rent, tax revenue, investment and employment. Tourism also has indirect economic effects, for example on hotels, restaurants and other service providers who shop from other companies to meet demand from tourists or by employees in the tourism industry using their income to pay rent, insurance or merchandise. These trickle-down effects seep down and support the economic development of regions where tourism develops and flourishes.

Exact quantification of the contributions and costs associated with tourism is challenging for many different reasons. The Nordic countries have individually (except the Faroe Islands and Greenland) prepared satellite accounts to get an overview of the economic effects of tourism, but to varying degrees worked with regional satellite accounts which can provide insight into the difference in the importance of tourism's economic contribution to regional economies. That is what this report is about.

We have prepared a report whose purpose is to introduce the potential of Regional Tourism satellite accounts and describe their function and weaknesses in estimating the effects of tourism on regional economies. We also assess whether there are preconditions for developing a joint Nordic tourism account by virtue of the recognized satellite methods. Part two of the report contributes with an overview of available tourism statistics and the status of the regional tourism accounts today in the individual Nordic countries. On the basis of this overview, we draw up perspectives for future development opportunities associated with using regional tourism accounts in the joint collaboration on tourism development in the Nordic countries in expert opinions in collaboration with Åland's research and statistics bureau ÅSUB and Center for regional and tourism research, CRT, Bornholm. 


\section{Sammenfatning}

Turisme har spillet en voksende rolle i de to sidste årtier i mange nordiske landes økonomiske udvikling, men efter at pandemien Covid-19 ramte har turismesektoren lidt under effekterne af minsket rejselyst og restriktioner. Forhåbentlig vil turismen kunne genrejses og igen have positive effeter for lokaløkonomien rundt omkring i den nordiske region og med den også de mange afledede økonomiske effekter af turismen.

Når folk rejser køber de varer og/eller tjenester som for eksempel overnatning, mad, souvenirs og aktivitieter. De handler måske ved forberedelsen af deres rejse (f.e. tasker, tøj og udstyr) eller i forbindelse med returrejsen. Før,under og efter rejsen er deres udgifter direkte forbundet med turismeaktivitieter som genererer direkte indtægter til virksomhederne, skatteindtægter til det offentlige, investeringer i nye strukturer og beskæftigelse. Turisme har også indirekte økonomiske effekter, for eksempel på hoteller, restauranter og andre tjenesteydere som handler i andre virksomheder for at møde efterspørgselen eller ved at ansatte i turismebranchen anvender sine indkomster til at betale leje, forsikringer eller handelsvarer. Disse trickle-down effekter diffunderer ud i andre sektorer og støtter den økonomiske udvikling i regioner hvor turismen udvikles og florerer.

En konkret kvantificering af bidragene og omkostningerne forbundet med turisme er udfordrende at beregne af forskellige årsager. De nordiske lande har hver for sig (foruden Færøerne og Grønland) udarbejdet satellitregnskaber for at få overblik over turismens økonomiske effekter, men kun i varierende grad arbejdet med regionale satellitregnskaber som kan give indblik i forskellene mellem turismens økonomiske bidrag til de enkelte regionale økonomier. Nærværende rapport belyser dette.

I rapporten er formålet at analysere Regionale Turisme satellitregnskabers potentiale og beskrive deres funktion og svagheder i estimeringen af turismens effekter på regionaløkonomien. Vi ser også på om der er grobund for at udvikle et fælles nordisk turismeregnskab med de anerkendte metoder for satellitregnskaber. Rapportens anden del bidrager med en oversigt over tilgængelig turisme statistik og de regionale turismeregnskabers status i dag i de enkelte nordiske lande. På baggrund af denne oversigt giver vi perspektiver for fremtidige udviklingsmuligheder ved at anvende regionale turismeregnskaber i et nordisk samarbejde. Perspektiverne baserer sig på ekspertudtalelser fra både Ålands forsknings og statistik bureau og Center for regional og turisme forskning Bornholm som hver især udvikler regionale turismeregnskaber. 


\section{Tourism in recent decades-growth and the economy}

This report provides an account of the increasing importance of tourism as an economic sector in most countries in the past two decades by considering data availability in the Nordic countries when it comes to describing tourism growth in the past 20 years and ways to measure economic impacts.

Prior to the coronavirus disease 2019 (COVID-19) pandemic, tourism had been one of the fastest growing economic sectors in the world over the past two decades (UNWTO, 2020). The Nordic countries were part of this trend, and tourist numbers increased enormously in some locations. The boom has offered both challenges and opportunities for the Nordic region. The challenges include the risk of environmental damage, deteriorating infrastructure, pollution, overcrowding and increased rents and property prices in popular areas (see Bogason, Karlsdóttir \& Broegaard, 2020), whereas the benefits include job creation and incomes for the local economy in tourist areas (Jones \& Munday, 2004). The question of how to manage tourism to benefit from its opportunities while limiting the negative consequences will be high on the agenda as the pandemic prompts a re-examination of the feasibility of tourism development (lonnaides \& Gyimóthy, 2020).

Tourism offers opportunities for rural areas in the Nordic Region facing population decline and job loss. In some of these regions, increased tourism may create valuable jobs, provide resident populations with new economic perspectives and prevent negative development spirals with the declining and ageing population (Almstedt, Lundmark \& Petterson, 2016). At the same time, the strong seasonality of tourism flows, the prevalence of low-paid service jobs in the tourism sector and capacity constraints on capital and labour constitute particular challenges in these areas (see discussions by e.g. Kauppila et al., 2009; Saarinen, 2003; Muller, 2013). While tourism is an increasingly important topic in regional development strategies, there are not always sufficient data and other quantitative evidence to estimate the economic cost and benefit returns comprehensively. Before the COVID-19 pandemic, this was the situation in the Nordic countries and the autonomous regions.

The local economic effect of tourism in Denmark was considerable, in that tourists spent a total of 132.5 billion DKK in 2018, and tourism returns created around 169 thousand jobs the same year (VisitDenmark, 2020).

In Norway, tourists spent 186 billion NOK in 2018 and tourism created $7.1 \%$ of total employment (SSB, 2020). In Sweden, foreign visitors' spending generated 306 billion SEK, or 33\% of the total consumption in the country in 2019 (for explanation of the consumption calculations see Cañada 2013, p.42-43). The export value of tourism was 100 billion SEK and tourism provided employment for 126 thousand people in the tourism sector (Tillväxtverket/Swedish Agency for Economic and Regional Growth and SCB, 2020).

In 2018, tourism employed 142 thousand people in Finland, with regional variations. Areas outside of the most populous urban areas accounted for over 57 thousand jobs (VisitFinland, 2020a; Statistics Finland, 2020). North Ostrobothnia and Lapland had the most people employed in tourism industries relative to the regions' working-age populations. The numbers of passengers at Finnish airports decreased by $91 \%$ in late 2020 , while domestic tourism in relation to accommodation nights by residents only decreased by $15 \%$ (Statistics Finland, 2020). While tourism rose in terms of numbers of foreign arrivals before 2020, travel in 2020 was characterised by residents holidaying at home in the summer. 


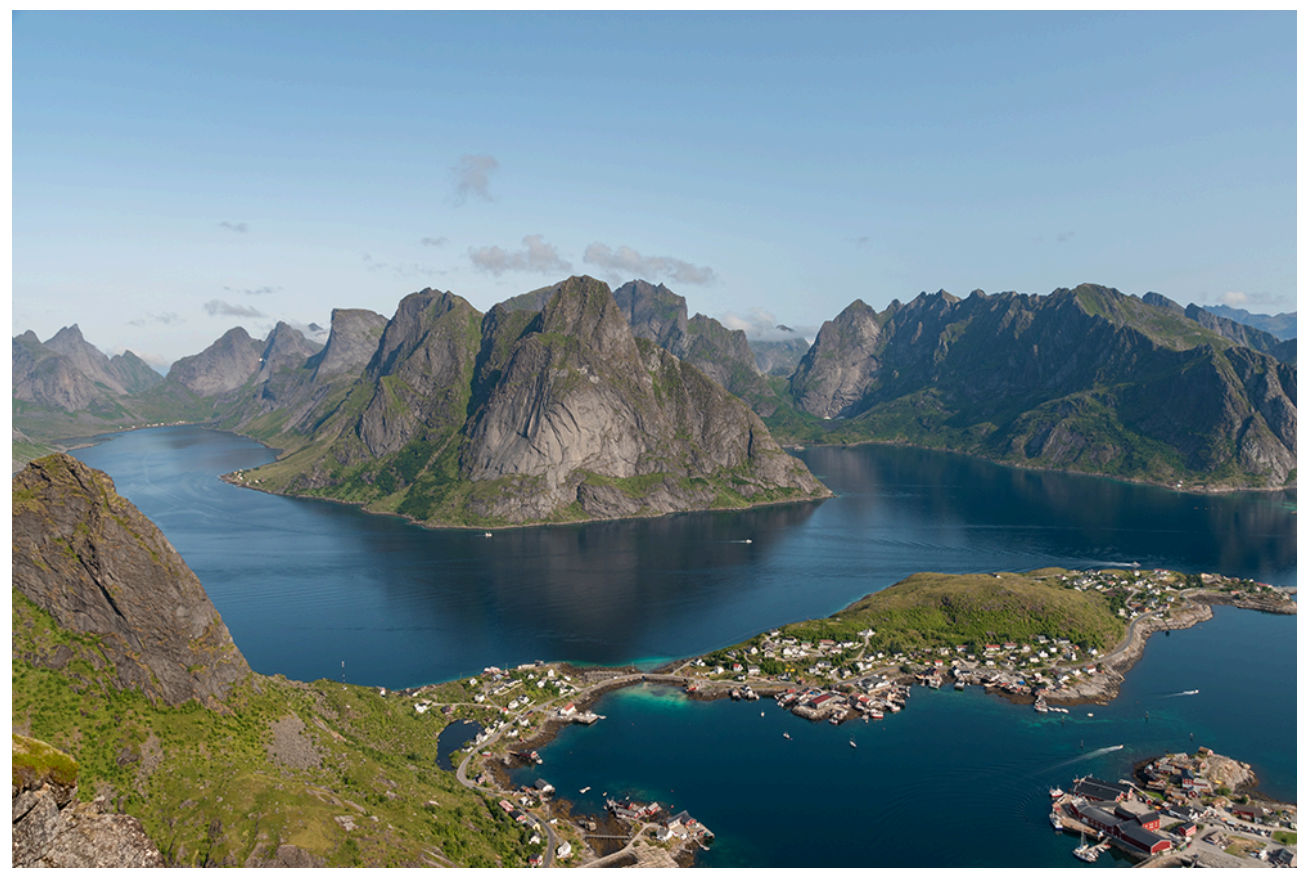

Reine in Moskoynes, Lofoten, Norway.

Photo: Freepik.com

Tourism in Iceland has increased enormously during the past decade. Between 2010 and 2016, the number of tourist arrivals more than tripled (Mandle 2018), peaking in 2018 at over 2 million visitors. By the end of 2019, 852 companies in rural Iceland (Landsbyggð) had built their economy on tourism and 9707 people were in full-time tourism work (of a total of 26,000-aviation not included). However, debt was on the rise and the prospects of economic returns from tourism were declining, although tourism generated at least one third of the income of the national economy. By late 2020 , over $12 \%$ of the working-age population was unemployed, the highest number since the establishment of the republic.

Åland's economy is highly dependent on tourism from ferry traffic in the Baltic Sea. Tourism is also one of Åland's most important export industries, with a total export value of EUR 330 million. Every fifth Ålander in the private sector works in tourism, and tourism indirectly contributes to jobs in industries that subcontract to the tourism industry (VisitAland, 2019). With the impact of COVID-19, Ålanders faced the highest unemployment rate in many decades with the highest rate at $13 \%$ in early summer 2020 . In the autumn it had declined slowly to around 9.3-9.9\% by end of that year. Youth unemployment (under 25 years) is highest by rate and as the pandemic situation extends long term unemployment is becoming a significant challenge (ÅSUB, 2020, ÅSUB 2020a). Tourism has risen in the Faroe Islands as it has for Greenland, and has increased in economic importance in both autonomous regions.

The COVID-19 pandemic has hit the tourism sector across co-operating Nordic regions and countries hard, and in some cases, the economy has plummeted, with rising unemployment. Owing to the sudden shift in tourism because of the COVID-19 pandemic, impacts, travel restrictions and hindrances to the country-level development of tourism have been in flux (UNWTO, 2020; OECD, 2020), requiring new knowledge. Given this situation, analyses of the economic effects of tourism are as relevant as ever in the Nordic context.

We ask: is it feasible to develop a common set of indicators measuring economic impacts on tourism on a regional level and how should we do it with the most commonly used and acknowledged methods at hand? 


\section{The importance of developing regional tourism satellite accounts}

Even if the tourism sector and tourism businesses are severely hit, some prospects should not be forgotten. One such prospect is that while urban tourism, accommodation and restaurant services have encountered hardships during this period, the flow of domestic travellers has breathed life into more remote destinations and less densely populated places. However, as mentioned above, there is insufficient quantitative evidence to estimate the precise costs of investments and benefits of economic returns from increased tourism.

Regional tourism satellite accounts (RTSAs) may fill some of these knowledge gaps. RTSAs have become an established tool used internationally to measure the impact of tourism on regional economies. RTSAs can measure supply and demand generated by tourism in various sectors and their contribution to macroeconomic indicators such as gross domestic product (GDP) or employment.

Against this backdrop, this report is intended first to introduce RTSAs and describe their function, strengths and weaknesses in estimating the impact of tourism on regional economies (a comparison with other methods is provided in the Appendix). The second part provides an overview of RTSAs and tourism statistics currently available in the Nordic region. Based on this overview, in the third section, perspectives for future development and the use of RTSAs in the Nordic Region are discussed in expert statements in cooperation with ÅSUB and CRT.

In this report, tourism is broadly understood to include all trips that 'take a traveller outside his/ her usual environment ${ }^{2}$ for less than a year and for a main purpose other than to be employed by a resident entity in the place visited' (see Frechtling, 2010). Based on this definition, tourism includes longer periods of holiday travel, day trips and visits to second homes, as well as international and domestic business travel (Smeral, 2006) and key concepts such as inbound, domestic and outbound tourism.

This project was built on original work by the Nordic Working Group for Sustainable Regional Development in the Arctic (2013-2016) but evolved in discussions between members of the Nordic Thematic group on Sustainable Rural Regional Development (2017-2020). This group described key developments in tourism management in the northern parts of Norden. These include analyses of how these areas have targeted key tourism segments, developed priorities and organized destination management. This project extends this analysis and investigates the role and impact of tourism on rural areas across the Nordic region (Bogason, Karlsdóttir, \& Broegaard, 2020).

2. A 'usual environment' is defined as 'the geographical area [...] within which an individual conduct his/her regular life routine' (Frechtling, 2010). 


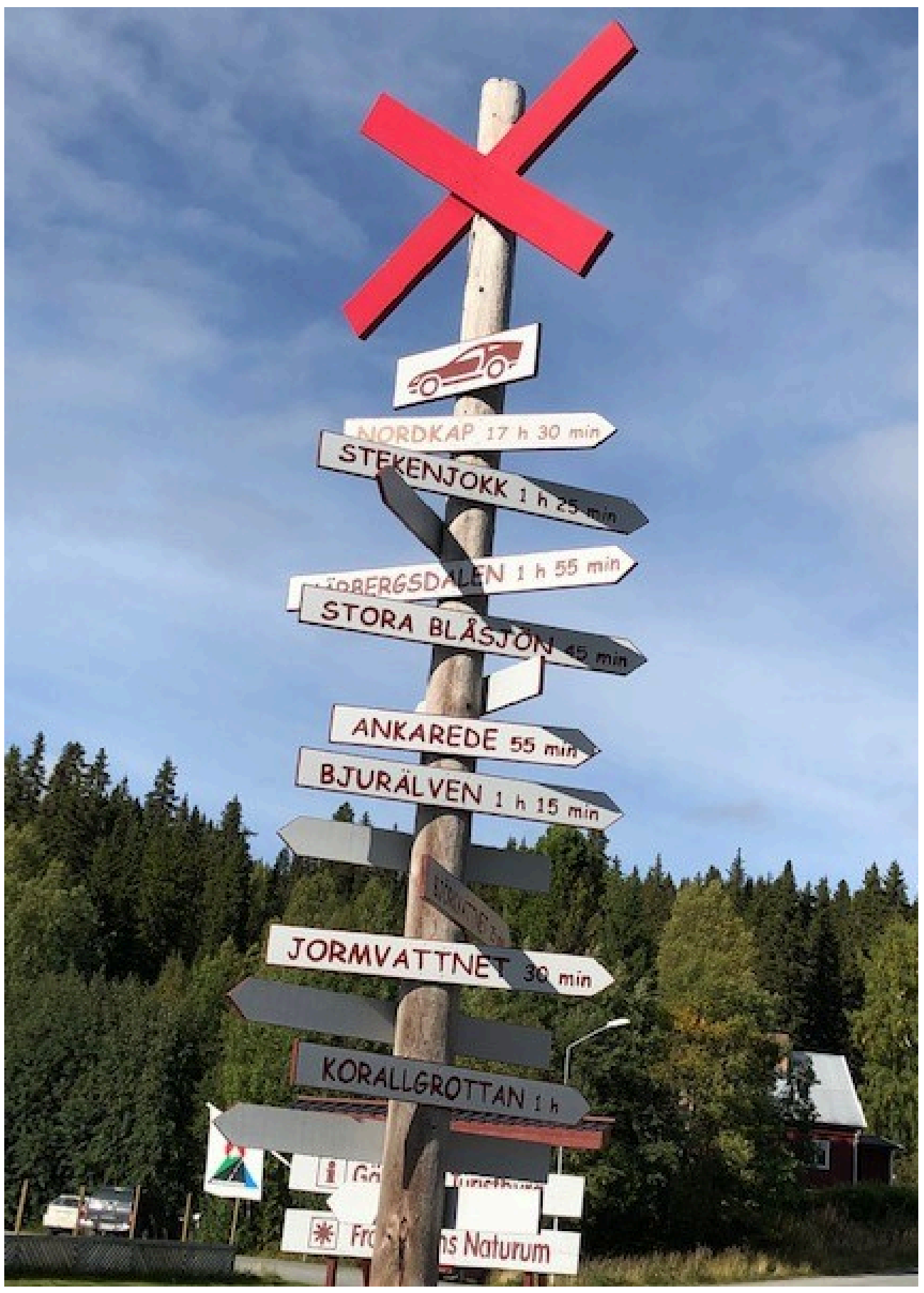

Direction sign in border town Gäddede, Sweden.

Photo: Anna Karlsdóttir 


\section{The history and role of tourism satellite account development}

TSAs were first developed and used in the 1980s and 1990s. Canada was a pioneer, developing one of the first TSAs in 1994. Other countries followed, including France, New Zealand, Austria, Poland, Singapore and Sweden (Frechtling, 2010; Jones et al., 2009; Rütter \& Berwert, 1999; Smeral, 2006). However, these statistical/accounting instruments are not analytical models per se. They are used in various TSA approaches and must be continuously updated because no widely accepted and common approach has been provided.

Over time, actors in several countries and institutions, such as the World Tourism Organisation (WTO, now the UNWTO) and Organisation for Economic Co-operation and Development (OECD), elaborated and refined the approach until a common methodological framework and standard could be agreed upon. This process culminated in 2008, when the United Nations Statistical Commission, UNWTO, OECD and Eurostat adopted two documents that define the core concepts, classifications and accounting rules for constructing a TSA-Tourism Satellite Account: Recommended Methodological Framework (2008 TSA:RMF)-which constituted a guideline for statistical offices to develop TSAs as well as RTSAs. This document plays a central role in most countries, as does the 2008 document International Recommendation for Tourism Statistics (see also Frechtling, 2009). These two documents now form a reference framework that countries and regions can use to compile tourism statistics and develop TSAs (Frechtling, 2010; for a recent overview of national-level TSAs in Europe, see Eurostat, 2017). Canada, Australia and Denmark are among the pioneers in applying these at the regional level (UNWTO, 2013). In addition to Canada and Australia, the Nordic countries developed TSAs or RTSAs earlier than many other industrialized countries.

TSAs are a static set of accounts to measure the size or configuration of the tourism sector (i.e. a distinctive set of activities in which visitors participate) in an economy. They are designed to complement the System of National Accounts (SNA), where the term 'satellite is derived from Kronenberg (2014) and Frent (2016). In other words, a TSA measures the direct contribution of a predefined tourism industry to the overall economy in a manner consistent with the SNA. There are also transport satellite accounts, health satellite accounts and environmental satellite accounts (SCB, 2018; Eurostat, 2020). The term 'account' refers to the characteristics of a TSA, including a set of tables that record transactions, sources and uses of resources by institutions (e.g. households) and sectors.

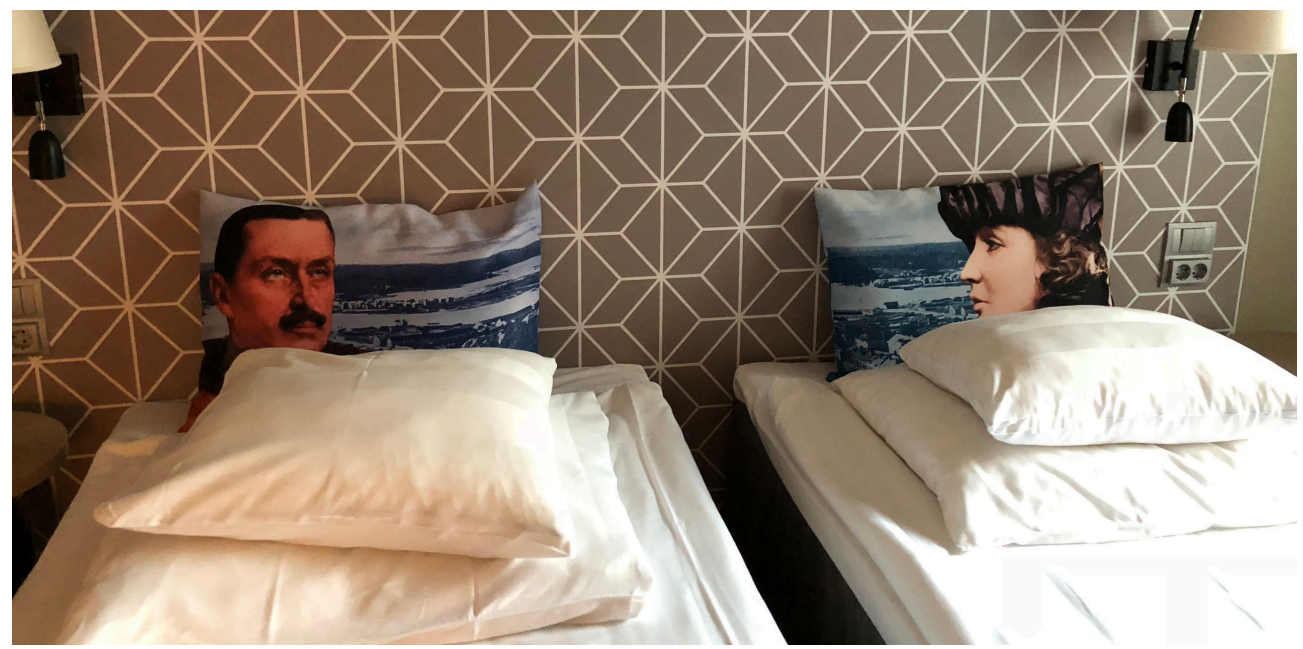

Beds in a hotel, Mikkeli, Finland.

Photo: Anna Karlsdóttir 


\subsection{Opportunities and challenges in economic measurement using tourism satellite accounts}

Tourism plays an increasingly significant role in the economic development of many Nordic regions. Despite the sudden collapse of tourism because of the COVID-19 pandemic, it is likely to rise again and have a significant impact on local economies in the Nordic region. When people travel, they pay for goods and/or services such as accommodation, food, souvenirs and activities. They may also buy goods or services in preparation for their trip (e.g. suitcases) or on their return (e.g. to replace goods lost during the trip). In all three cases, their expenditure is directly linked to tourism activity, which generates profits, rent, tax revenue, investment and employment (Frechtling, 1999, 2009). Tourism has also indirect economic effects, for instance, on hotels, restaurants and other service providers purchasing from other companies to meet tourist demand or by having local employees of tourism companies spend their salary on rent, insurance or retail goods (Jones \& Munday, 2004). These trickle-down effects support economic development in tourist regions.

Exact quantification of the contributions and costs of tourism is challenging for several reasons. First, precise data are not always available (Jones \& Munday, 2004). While the productivity of sectors such as agriculture or manufacturing can be measured based on output, tourism is more appropriately determined by demand (Smeral, 2006; Madsen \& Zhang, 2010). Furthermore, while other sectors can be defined as distinct industries, tourism is not a discrete and separately measurable industrial sector. Instead, a range of goods and services produced by a range of sectors are consumed by tourists (Rütter \& Berwert, 1999; Jones et al., 2009; Smeral, 2006). Many of these may also be consumed by locals (Smeral, 2006). Conversely, many goods and services consumed by tourists, such as clothing, groceries and books, may not have been produced specifically for this target group. The economic impact of tourism on regional development is therefore difficult to grasp and can easily be estimated incorrectly (Jones \& Munday, 2004).

To assess the economic effects of tourism, different methods have been developed and used by tourism researchers, including impact models, cost-benefit models, social accounting matrices (SAMs) and computable general equilibrium (CGE) models, each with its own strengths and weaknesses (see Frechtling, 2009; Madsen \& Zhang, 2010; Rossouw \& Saayman, 2011; and Dwyer et al., 2007). The Appendix provides a brief account of various applied methods. However, in recent years, TSAs have been increasingly used as the standard tool to measure the direct economic contributions of tourism (Cañada, 2013; Dwyer et al., 2007).

SNAs can be thought of as a series of input-output spreadsheets listing the various sectors or industries that comprise the economy, the commodities produced and their annual value. Other spreadsheets list the annual value of the commodities consumed by each industry. A third type of spreadsheet lists private and public demand, investment and consumption (Smeral, 2006). TSAs can be considered to be a subset of these spreadsheets that 'claim' some of the goods and services recorded in the SNA for tourism (Pham \& Dwyer, 2013). Hence, TSAs identify industry outputs that are consumed or purchased for tourism as well as their contribution to key macroeconomic indicators such as GDP, national income and employment (Frechtling, 2010; Jones et al., 2009). In this way, it is possible to evaluate the role of tourism in various industrial sectors and the overall economy of a country and to analyse its links with other economic activities (Dwyer et al., 2007; Smeral, 2006; Jones \& Munday, 2004). TSAs also facilitate international comparisons of tourism activities and allow changes to be tracked over time (Dwyer et al., 2007, 2008; Frechtling, 1999). TSAs are usually based on industry data, input-output tables in the SNA and/or visitor surveys (Pham \& Dwyer, 2013). 


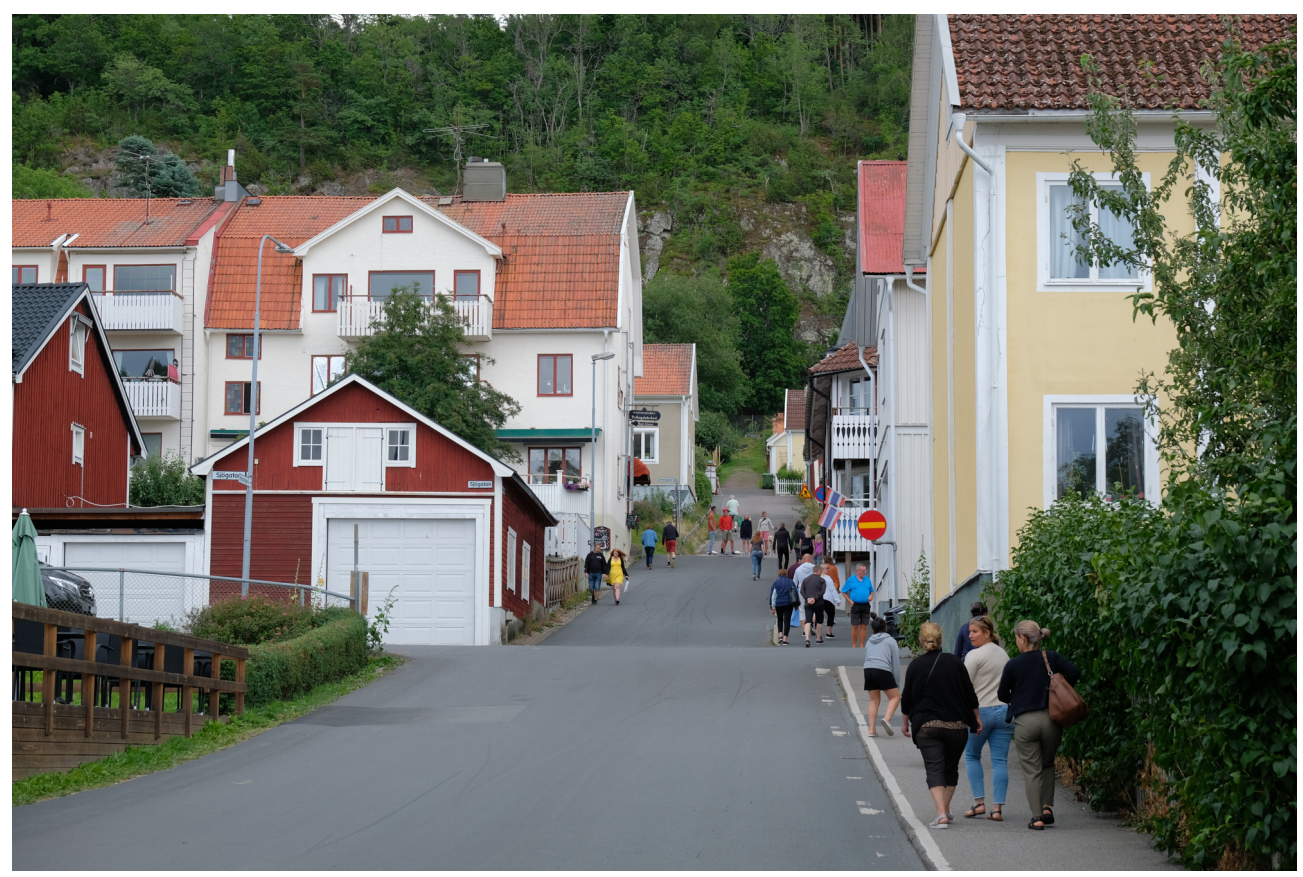

A popular tourist town Gränna in Sweden.

Photo: Artūras Zelenkauskas

The role and uses of RTSAs may be as follows (Laimer, 2017). They help to benchmark the success of tourism policies, can provide a basis on which to evaluate tourism development in relation to the rest of the economy, work as fact base for tourism policy issues and can serve as an initial basis on which to justify and subsidize tourism activities. Most importantly, they provide data on various aspects of tourism.

According to this established reference framework, a TSA should consist of 10 tables, six of which constitute the core of each TSA. The first four tables measure tourist consumption (inbound tourism expenditure, domestic tourism expenditure, outbound tourism expenditure and internal tourism consumption), the fifth measures the output of tourism industries and the sixth connects the previous ones and estimates the gross value added by each tourism supply industry. The four remaining tables measure employment in tourism industries, investment in productive capital, collective tourist consumption and tourism flows/characteristics of enterprises (Cañada, 2013). Because of its value in analysing the economic impact of tourism, increasing efforts have been made in recent years to adapt the TSA methodology for sub-national regions (hereafter, regional TSAs or RTSAs).

The input-output structure of TSAs is not without challenges, in particular, when they are applied in a regional context. First, extensive data and statistical capacity are required for their construction, and these are not always readily available (Cañada, 2013; OECD, 2016). Many tourism-related activities may be undertaken by very small businesses which may not always be legally required to register detailed business accounts. Owners of micro-businesses may also not always explicitly draw or register a salary from their work, which may hamper endeavours to assess tourism-related labour inputs and outcomes. Reliable statistics for the construction of TSAs may also be delayed, when timeliness is usually of crucial importance for users (OECD, 2010). Second, not all tourist activities may be easily assigned to a specific region. For instance, if tourism services are provided by central governments or by multinational or multiregional companies, it may be difficult to assign transactions or outputs to a specific territory (Frechtling, 2009, 2010; Cañada, 2013). Third, tourism and hence employment opportunities may be seasonal, and labour statistics do not always reflect this (Jones et al., 2003). Some of these data gaps can be filled, for instance, through tourist surveys, but these may be costly and time 
consuming to develop and implement (Jones \& Munday, 2004).

Finally, TSAs do not capture the full impact of tourism on a region. For instance, the indirect or intermediate economic effects of tourism, such as those triggered by the delivery linkages in the economy, are not typically included in a TSA (Smeral, 2015). Importantly, TSAs also do not usually measure the environmental or social costs of tourism. For a full appreciation of the effects of tourism on regional development, these non-economic effects must also be considered. Modelling approaches can be used to extend TSAs and capture more fully non-market commodities such as carbon emissions or natural resource consumption, but these are methodologically more challenging and demanding in terms of both time and cost (Jones \& Munday, 2007; Madsen \& Zhang, 2010; Frenț, 2018). Whereas the RTSA tables provide a benchmark for the current situation and aid in the description of historical development, model analyses are needed to make ex-ante calculations of future development. With the modelling tools, all kinds of 'what if' questions can be studied. Thus, TSAs have a limited role in tourism accounts themselves because they must be combined with regional accounts, input-output or CGE models to analyse different policy options (for a brief descriptions of data requirements and limitations and the possibilities of various other methods for the economic impacts of tourism, see the Appendix).

\begin{tabular}{|c|c|c|c|c|}
\hline \multicolumn{5}{|c|}{ Country of reference } \\
\hline \multicolumn{5}{|c|}{$\longleftarrow$ Tourism demand } \\
\hline \multicolumn{5}{|l|}{$\begin{array}{l}\text { Table } 1 . \\
\text { Inbound tourism } \\
\text { expenditure by } \\
\text { products and } \\
\text { classes of visitors }\end{array}$} \\
\hline \multirow{2}{*}{$\begin{array}{l}\text { Table } 2 . \\
\text { Domestic } \\
\text { tourism } \\
\text { expenditure by } \\
\text { product, class of } \\
\text { visitor and type } \\
\text { of trip }\end{array}$} & $\begin{array}{l}\text { Table } 4 \text {. } \\
\text { Internal tourism } \\
\text { consumption of } \\
\text { products }\end{array}$ & $\begin{array}{l}\text { Table } 6 \text {. } \\
\text { Total domestic } \\
\text { supply and internal } \\
\text { consumption (at } \\
\text { purchaser prices) }\end{array}$ & $\begin{array}{l}\text { Table } 5 \text {. } \\
\text { Production } \\
\text { accounts of } \\
\text { tourism and other } \\
\text { industries (at basic } \\
\text { prices) }\end{array}$ & \\
\hline & $\begin{array}{l}\text { Other } \\
\text { components } \\
\text { of tourism } \\
\text { consumption: } \\
\text { (a) vacation } \\
\text { accommodation } \\
\text { services; } \\
\text { (b) tourism social } \\
\text { transfers in kind; } \\
\text { (c) other imputed } \\
\text { consumption }\end{array}$ & & & $\begin{array}{l}\text { Table } 7 . \\
\text { Employment } \\
\text { in the tourism } \\
\text { industry }\end{array}$ \\
\hline Table outputs: & $\begin{array}{l}\text { Internal tourism } \\
\text { expenditure: } \\
\text { internal tourism } \\
\text { consumption } \\
\text { Outcome I }\end{array}$ & $\begin{array}{l}\text { Tourism direct } \\
\text { gross value added; } \\
\text { tourism direct } \\
\text { gross domestic } \\
\text { product } \\
\text { Outcome II }\end{array}$ & $\begin{array}{l}\text { Gross value } \\
\text { added of tourism } \\
\text { Industries } \\
\text { Outcome III }\end{array}$ & $\begin{array}{l}\text { Tourism } \\
\text { employment } \\
\text { (tourism direct } \\
\text { employment) } \\
\text { Outcome IV }\end{array}$ \\
\hline
\end{tabular}

Figure 1. TSA table requirements (adapted from Frechtling, 2010). 
The role of RTSAs can be problematized. The clear advantages of a satellite account are that it supplements the national accounts and gives detailed accounting of one specific area, such as tourism and the environment. The disadvantages are that it is costly and the data requirements are very high. Nonetheless, TSAs have many advantages: they are relatively straightforward to interpret if linked to key economic indicators, so they are easy for policymakers, national tourism organizations, statistical offices, businesses and other actors to use (Jones et al., 2003). Especially in depopulated or economically challenged regions, there can be value in understanding the contribution of tourism to economic development and to resolving underemployment issues. RTSAs could also assist comparisons of similar regions and show the benefits of tourism (Frechtling, 2009). TSAs can identify particularly profitable types of tourist activities, which could then be promoted by policy initiatives (Frenț, 2018; OECD, 2010).

\subsection{Constructing regional tourism satellite accounts}

Jones and colleagues $(2009,2010)$ distinguish two possible approaches to developing RTSAs-'top-down' and 'bottom-up' ${ }^{\prime 3}$. Both approaches can be combined in mixed-method approaches (Cañada, 2013).

The top-down approach involves regionalizing a national TSA. Key results from national TSAs must be broken down and allocated to different regions. For instance, the allocation could be based on survey results, a key indicator or statistics that can be disaggregated to the regional level. The advantages of this method are that it can be undertaken at low cost, in particular, if good-quality data and/or business, tourism or household surveys that can easily be regionalized are available. RTSAs that rely on such statistics may also be relatively easy to update when new data become available. If the approach includes all regions of the country, it can also produce results that are comparable and consistent. Owing to the structure and data requirements of such an approach, national statistical offices should be involved in the process of regionalizing a national TSA.

Challenges may arise if centrally collected production and/or consumption data cannot be easily allocated to specific regions. Moreover, because a central set of definitions and/or classifications will be used for the whole country, it may not always be possible to measure regional specificities adequately in terms of tourist activities or consumption patterns (Jones et al., 2009). Therefore, the results of the top-down approach may be less useful to local policymakers and stakeholders (Jones \& Munday, 2010).

The bottom-up approach can avoid such conceptual shortcomings. An RTSA is developed for a specific region. One of the main advantages of this approach is that it can be tailored to the characteristics and specificities of tourism activities in that region. For instance, regional surveys that provide input to the RTSA can be tailored to specific policy interests and regional circumstances. The downsides and potential barriers to the bottom-up approach are that it requires large amounts of data and can cost considerable time and money. Its results may also not be directly comparable with those of other regions in the same country or abroad (Jones et al., 2009). Therefore, Cañada (2013) stresses that the national perspective and connection to the country's overall TSA framework should always be retained and indeed be 'an obligatory reference point for regional TSAs' (Cañada, 2013, p.5).

In a publication by the World Tourism Organization, Cañada (2013) defines a common methodological framework for this type of RTSA and describes the core elements and concepts that should be included. He specifies five tables that should form its basis ${ }^{4}$ :

- internal tourism consumption,

- production accounts of characteristic industries,

3. Cañada (2013) refers to these as the 'interregional approach' and the 'regional approach', respectively.

4. See also Jones and Munday (2010) for a simplified approach to constructing RTSAs where regional input-output tables are not available. 
- supply and internal tourism consumption,

- employment in the tourism industries, and

- gross fixed-capital formation of tourism industries.

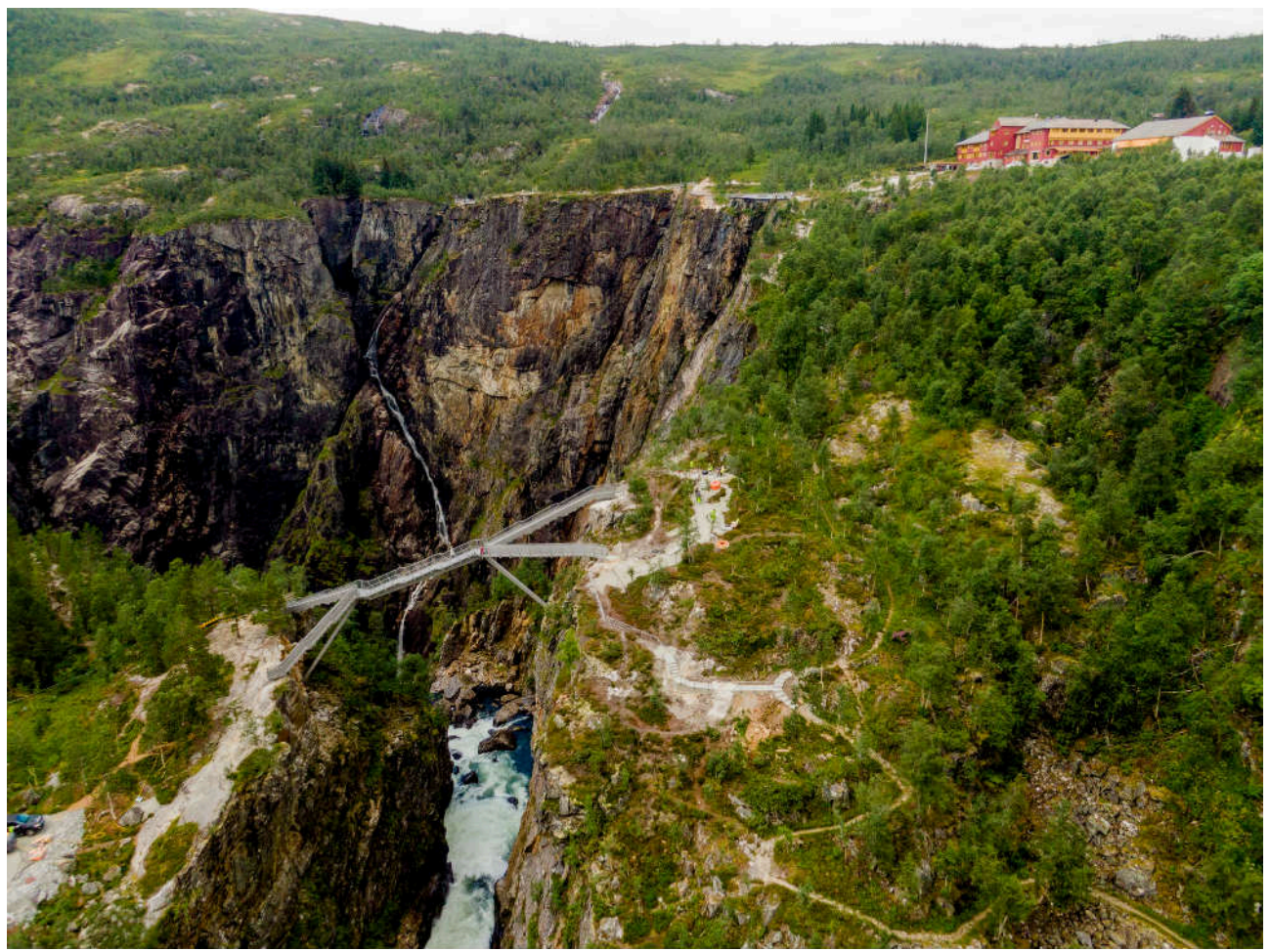

The Voringsfossen bridge in Norway.

Photo: Scanpix.com 


\section{Guidelines and manuals for developing TSAs from major international organizations}

The UNWTO (United Nations World Tourism Organization) is an intergovernmental organization with a secretariat based in Madrid, Spain. The UNWTO has 159 member states, six associate members, two observers and over 500 affiliate members worldwide. The secretariat is led by the Secretary-General and organized into departments covering issues such as sustainability, education, tourism trends and marketing, sustainable development, statistics and TSAs, destination management, ethics and risk and crisis management. Since 1999, the UNWTO has published reports on the conceptual framework of TSAs. To provide a sound basis for the international comparison of the economic impacts of tourism, the 1999 publication included comprehensive recommendations for countries wishing to implement TSAs. TSAs were presented as a tool for anyone interested in the economic importance of tourism despite the development of many other methods of measuring economic impacts. It included the basic system of classifications, general guidelines, definitions, tables and aggregates linked to the standard tables of the United Nations System of National Accounts. This ongoing TSA process of measuring the economic importance of different segments of tourism entailed consideration of the information sources and methods required to include employment (UNWTO, 2008). In 2014, the UNWTO held a global meeting on the application of RTSAs following the publication of methodological recommendations (Cañada, 2013).

\section{It has been consistent in recommending a set of 10 summary tables of underlying data:}

- inbound domestic tourism and outbound tourism expenditure,

- internal tourism expenditure,

- production accounts of tourism industries,

- gross value added (GVA) and gross domestic product (GDP) attributable to tourism,

- employment,

- investment,

- government consumption, and

- non-monetary indicators.

(TSA data provide a better understanding of the place of tourism in an economy and enable a range of economic analyses (see UNWTO, 2008). For example, it is possible to apply economic modelling techniques (such as input-output analyses) to TSA data to estimate the indirect and induced effects of tourism in an economy.)

The principles of the Tourism Satellite Account: Recommended Methodological Framework 2008 (United Nations, 2010) are mostly designed for the national level and thus have limitations when applied at the regional level. The UN statistical office was thus part of this development in parallel with the UNWTO.

The OECD and Statistical Office of the European Communities (Eurostat) co-operated with UNWTO and UN statistical office on the recommended methodological framework in the 2008 publication (UNWTO, 2008). Eurostat disseminates national results for a set of key TSA indicators for countries in the European Union and European Free Trade Association that have compiled TSAs in recent reference years. The most recent publication was a follow-up of the 2016 Tourism Satellite Accounts in Europe (Eurostat, 2019).

The Nordic model was stipulated by the Nordic Council of Ministers and used for the evaluation of the economic impacts of tourism in the Nordic peripheries (Rinne \& Saastamoinen, 2005; Saarinen, 2003). Only older tourism literature refers to it and mostly from Finland, so it has not been widely applied for over 15 years in the Nordic region. The strength of this input-output 
model with direct, indirect and induced income, as well as employment impact at the local or regional levels, was that it was developed to track income leakage. Why this model was abandoned remains unclear. The most likely reason is that TSAs were established as the international standard for calculating the economic impacts of tourism (Frechtling \& Smeral, 2010) and once they had been adopted in individual countries and gradually more countries followed, it became the standard.

One of the shortcomings of these tourism-related economic impact approaches and their relevance in current times is that they do not really address how patterns of consumption (tourism demand) and production (tourism supply) affect the environment. In recent years, Eurostat has been involved in developing methodological frameworks (Eurostat, 2020), and the Swedish Statistical Bureau is developing a link between TSAs and the environment (SCB, 2018).

In the following section, we summarize the developments towards TSAs and RTSAs in each Nordic country and region. In the final section, these efforts are evaluated and recommendations for next steps are provided in two expert statements that have been combined into one.

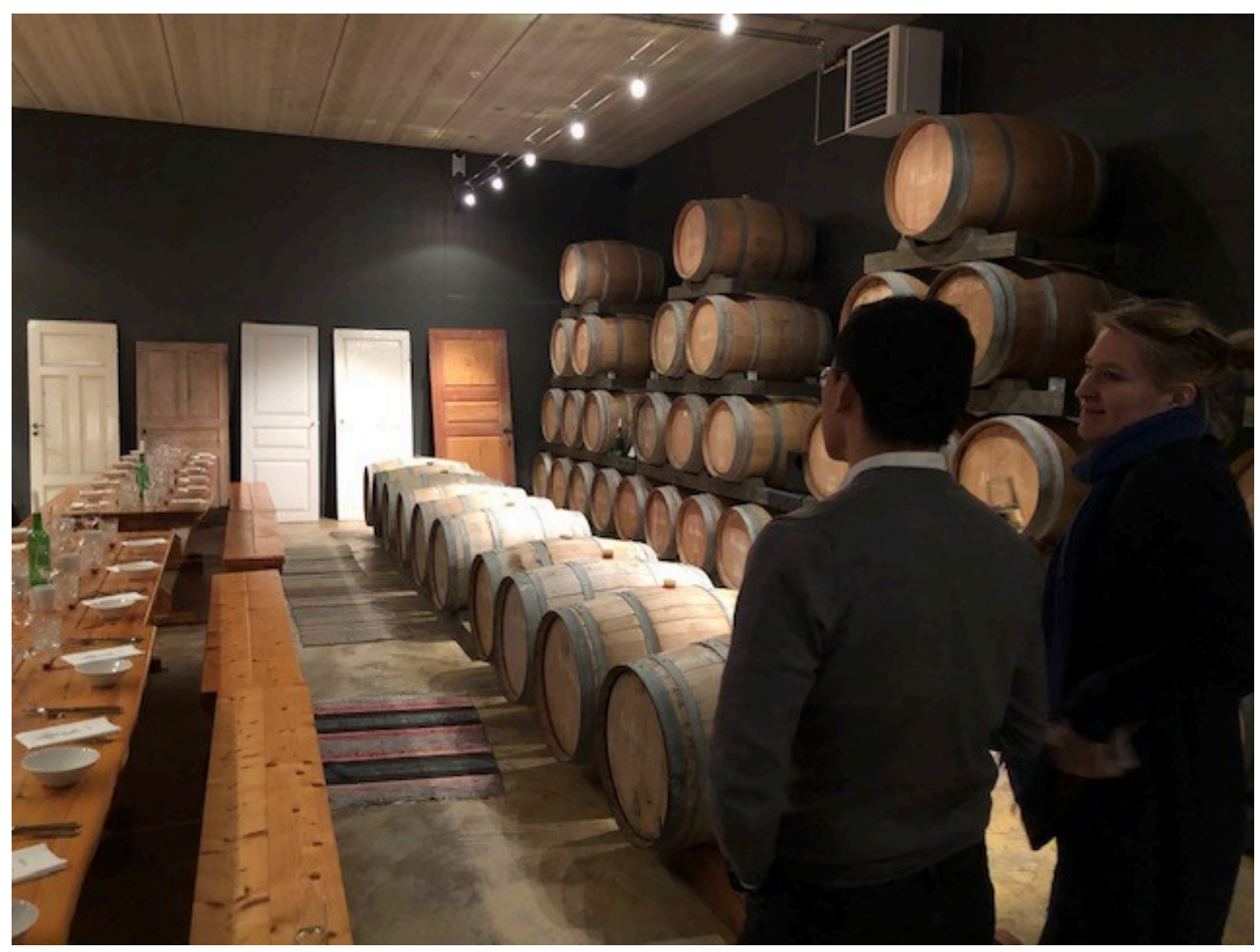

Micro brewery and restaurant in Kastelholm, Åland.

Photo: Anna Karlsdóttir 


\section{Nordic regional tourism satellite accounts-description and main tables by country}

This section summarizes the main TSA studies and datasets available in each country. Particular emphasis has been placed on identifying endeavours towards the calculation of RTSAs in Nordic countries.

The studies and data sources presented below were obtained through the following strategies. For each Nordic country and region (the Faroe Islands, Greenland and Åland), a search on Google.com and Google Scholar with the keywords "name of country/region + tourism satellite account" was conducted to identify the academic and grey literature on TSAs. In addition, the webpage and online databases of the national statistical institute of each country and region were searched for relevant statistics and datasets on tourism and/or TSAs. In some countries, relevant datasets were not available on the statistics institute databases, but on the databases of national tourism organizations; these were consulted as well. All of this research was conducted in English; in the case of Sweden and Åland, some publications written in Swedish were included. The search was also conducted in the second part of June 2019 and May 2020 with Danish and Norwegian as the search languages.

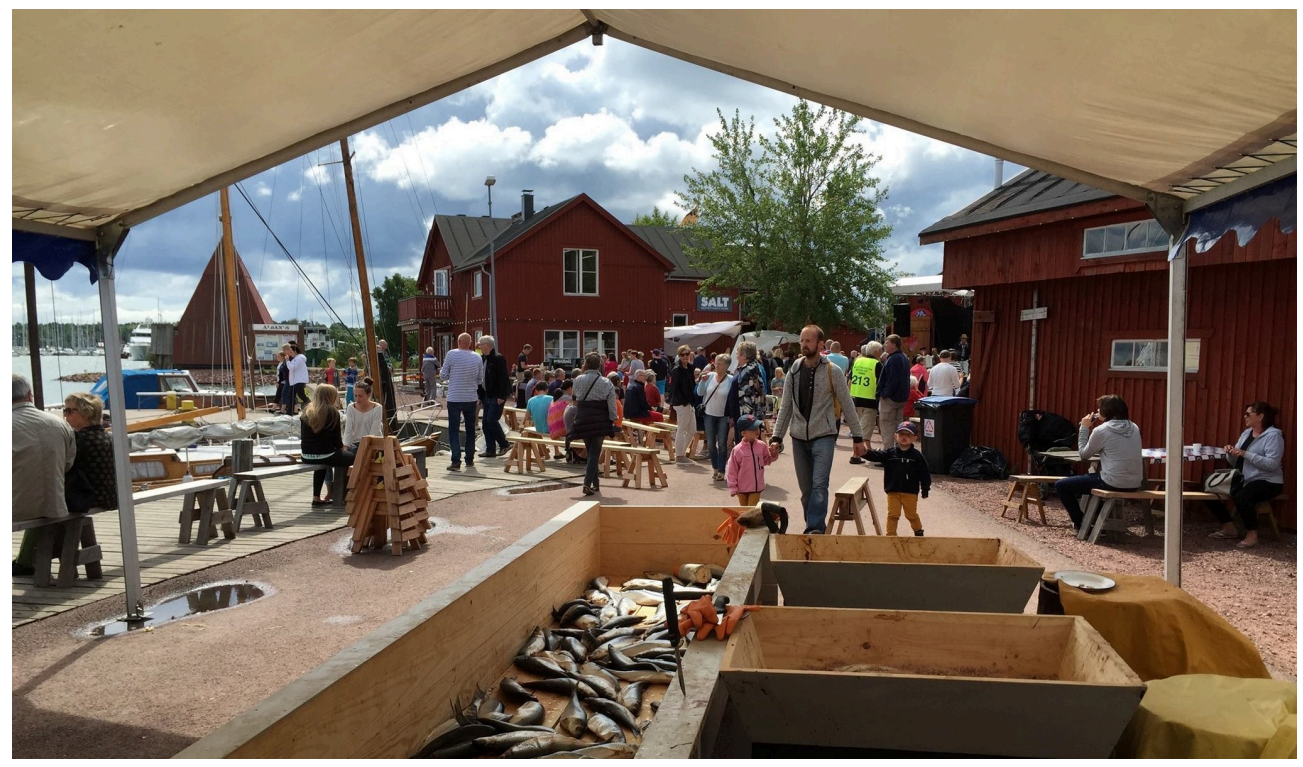

Guests in Marihamn port on the Nordic coastal culture festival in Åland.

Photo: Anna Karlsdóttir

\subsection{Denmark}

Among the Nordic countries, Denmark currently appears to have the most advanced system and the most extensive experience in calculating RTSAs. The Institute for Local Government Studies (AKF), the Danish Tourism Board, VisitDenmark and Statistics Denmark developed the first national-level TSA for the reference year 2000 in 2003/2004. The first RTSAs for the period 2000 to 2004 were published in 2006. In the same year, the Centre for Regional and Tourism Research (CRT) assumed responsibility for compiling TSAs from the AKF and now collaborates 
with VisitDenmark (Eurostat, 2009). Since then, RTSAs have been published on VisitDenmark's webpage on a yearly basis. These are consistent with the Danish national accounts and in line with international documents and recommendations for the construction of TSAs (Zhang, 2019). Methodological changes and improvements have been made in recent years, so the RTSA results are not fully comparable over time.

The Danish RTSA uses the 'bottom-up' method. The RTSA is based on a regional model, LINE. The latter is an interregional macroeconomic CGE model based on a SAM framework (Zhang, 2001). The RTSA provides information on tourism consumption by categories of visitors, production accounts of different tourism industries and employment in the tourism industry at the municipal level, among others (Zhang, 2001, 2014). It can capture the direct, indirect and induced economic effects of tourism (Zhang et al., 2007). The RTSAs are based on statistics provided by Statistics Denmark (e.g. accommodation facilities, census data, national accounts data, regional production data, register data), as well as on a tourism survey, Tøbbe, conducted every 3 years (Zhang, 2019; Zhang, 2018; OECD, 2016). More than 10,000 visitors are interviewed in each survey round covering topics such as destination choices, consumption and satisfaction with their travels (VisitDenmark, 2018).

Statistics Denmark has published the following tourism-related datasets on its online database on hotels, holiday centres and youth hostels, holiday dwellings, camping sites, marinas and holiday and business trips (see Appendix 2 for the tables, indicator name, details and reference period). The available regional statistics are in almost all datasets on accommodation (hotels and guesthouses and holiday houses/cottages back to either 1992 or 2004, in some of the campsite statistics and on nights spent at marinas). The following maps illustrate the results of RTSAs processed by CRT (Zhang 2018, 2019) for VisitDenmark (2018) on tourism consumption by region and economic importance in relation to GDP and employment..

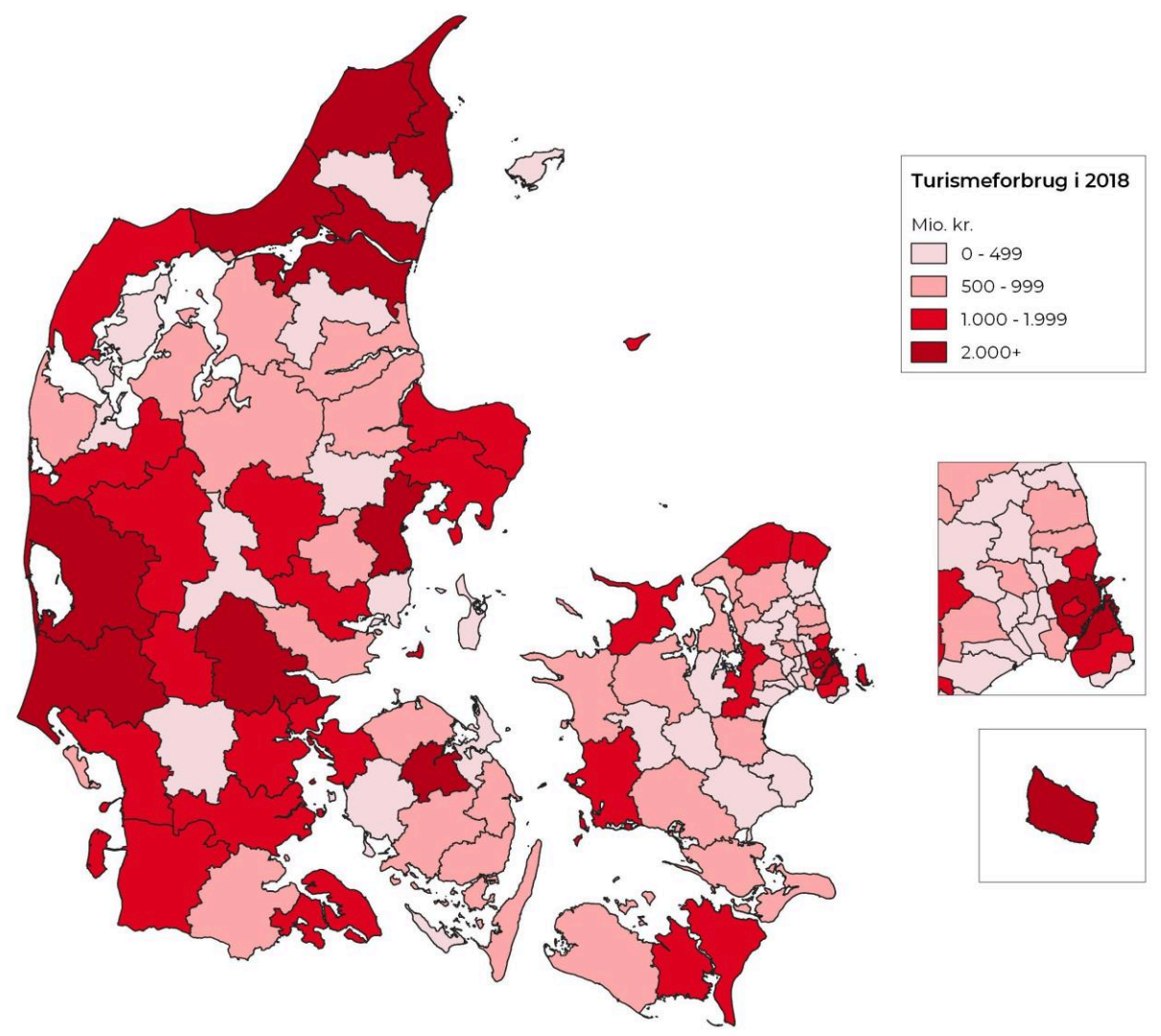

Map 1. Tourism consumption in 2018 in Million (mio) kr.

Source: VisitDenmark. 

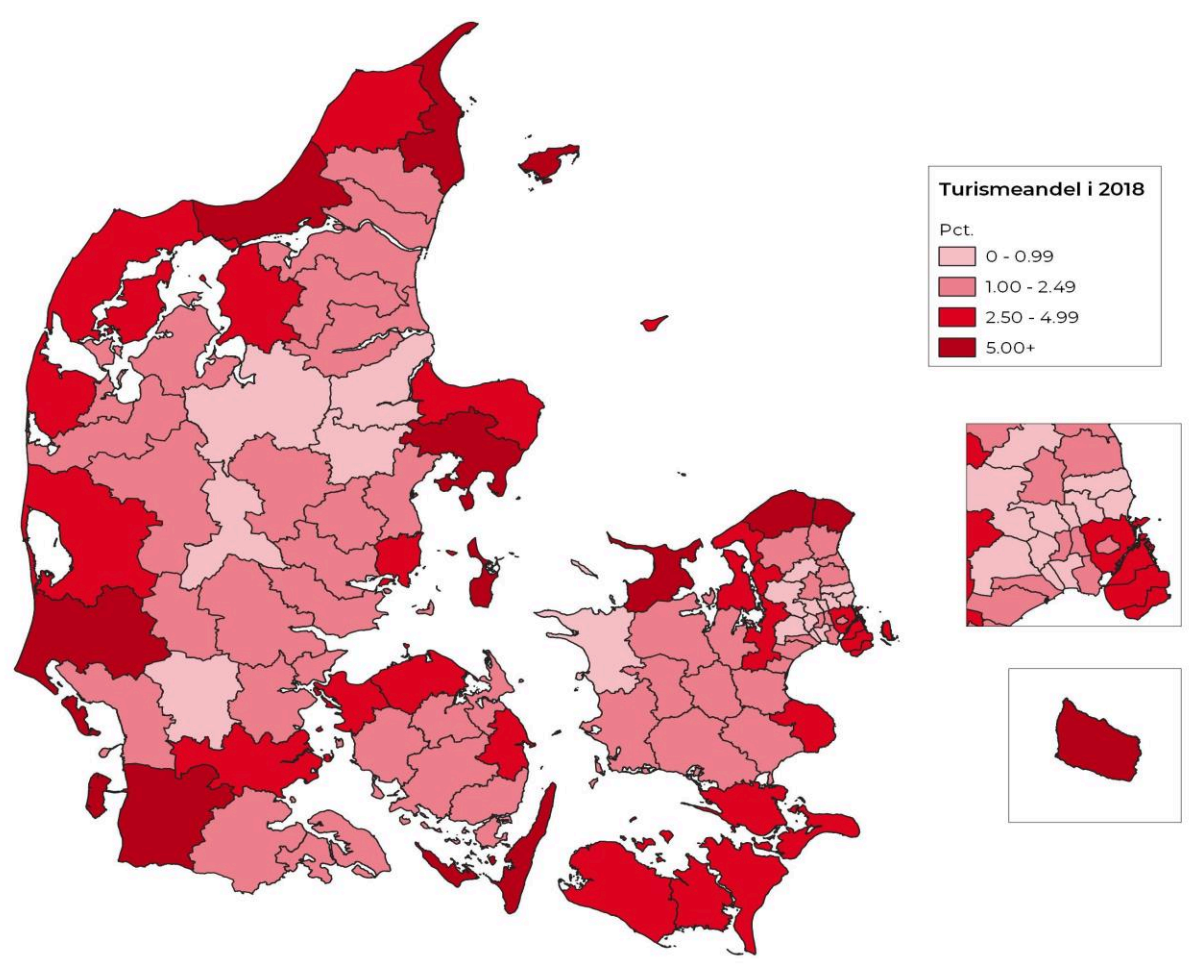

Map 2. Tourism share (\%) in 2018.

Source: VisitDenmark.
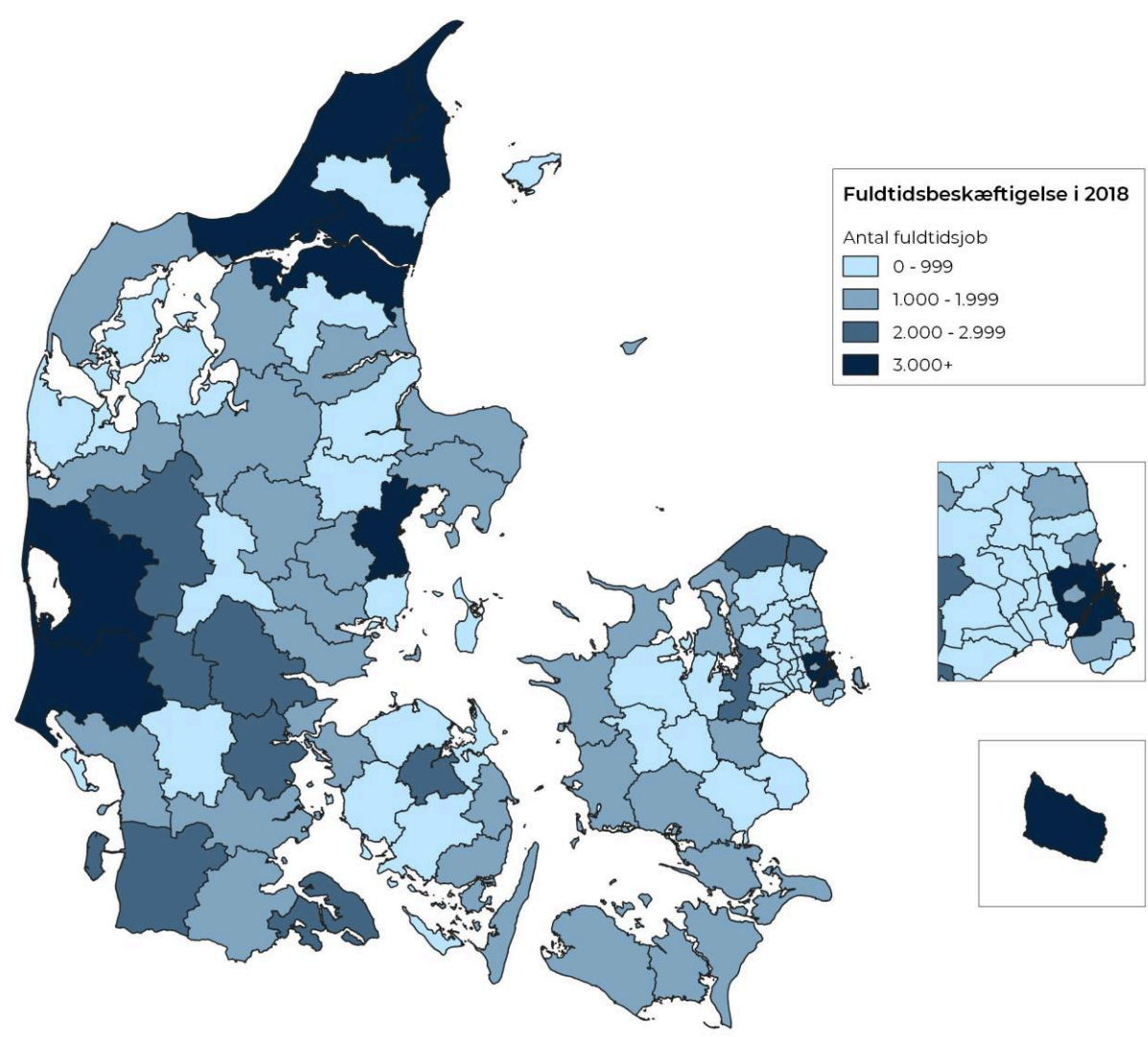

Map 3. Fulltime employment - number of fulltime jobs in 2018.

Source: VisitDenmark. 


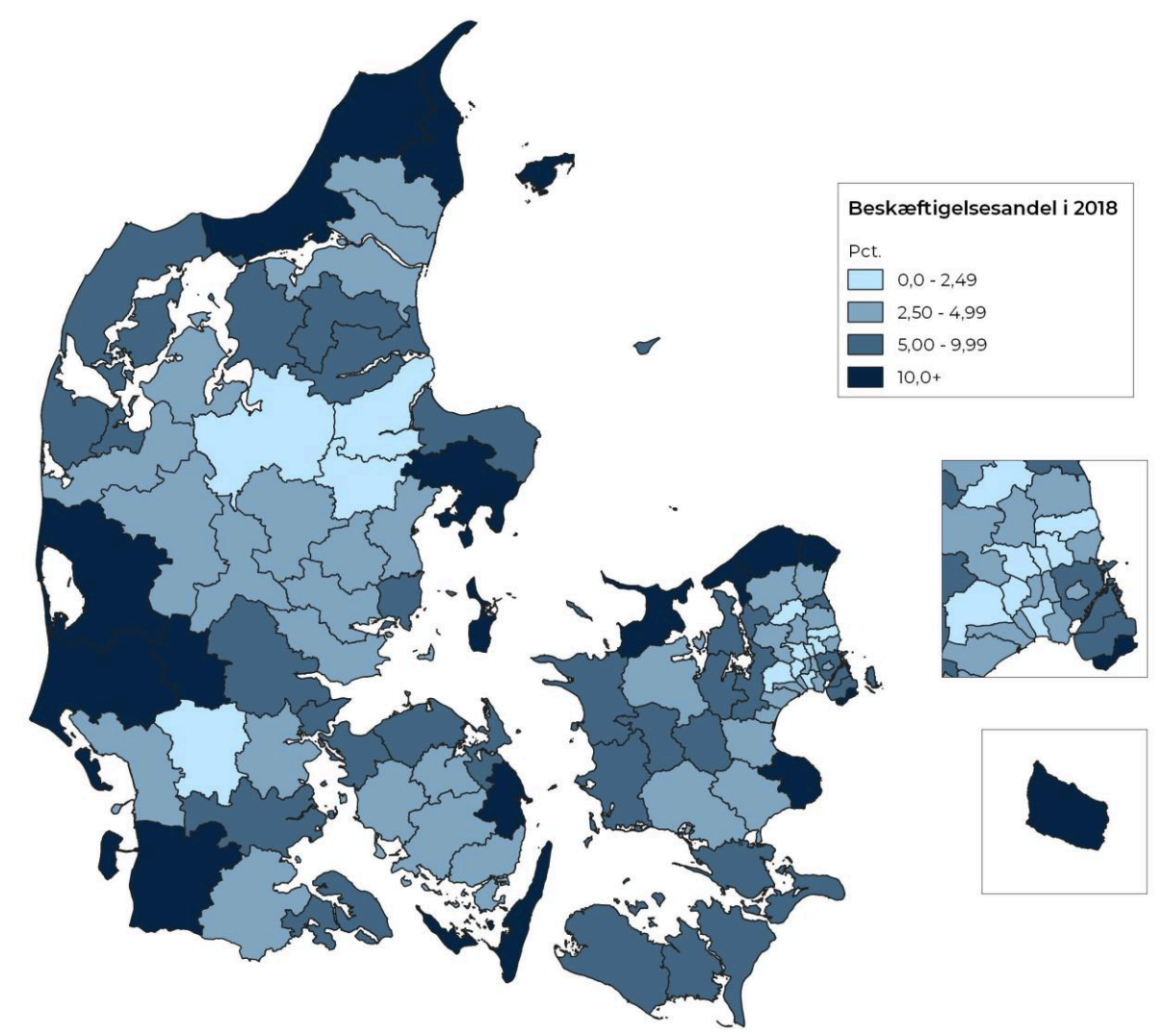

Map 4. Employment share (\%) in 2018.

Source: VisitDenmark.

According to the latest RTSA figures, the average job generation effect in Denmark was 1,700 full-time jobs per municipality, with great variation between municipalities (see Maps 4 and 5). This is calculated as total employment from tourism including direct, indirect and induced effects (VisitDenmark, 2019). As the maps above and TSA results show, a large share of tourism accumulates in a small number of municipalities. The 10 largest municipalities received $48 \%$ of tourism consumption. Århus and the Capital region are the largest recipients of tourism income, but coastal municipalities such as Varde, Ringkøbing-Skjern, Frederikshavn, Jammerbugt, Bornholm and Hjørring accounted for $32.8 \%$ of tourism consumption in 2018.

\subsection{Finland}

Statistics Finland and Travel Development Finland, Ltd., first published a preliminary TSA for 1999. After this first endeavour, Statistics Finland developed a consistent method for satellite accounts and produced final TSA tables for 1995 to 2001 (Statistics Finland, 2004). Since then, national-level TSAs have been published annually (Eurostat, 2009).

RTSAs were developed in 2005/2006 at the level with 2002 as the reference year (for 21 Finnish regions). The Finnish RTSA is based on Statistic Finland's national and regional accounts and supply-and-use tables, as well as the national-level TSA, border interview surveys ${ }^{5}$, accommodation statistics, travel, industry and labour force surveys, a passenger transport survey, employment statistics and the personal tax register. They contain 20 tables (see the Appendix and the table below as examples). A survey of industries with tourism characteristics

5. Åland is not part of this survey. Accommodation statistics and a survey conducted by Statistics and Research Åland provide comparable information (Konttinen, 2006). 
was also conducted (Konttinen, 2006). The results revealed that tourism is an important sector for the Finnish economy and has been on the rise, much more in some regions (e.g. Uusimaa, Varsinais-Suomi, Pirkanmaa) than in others. However, the North Ostrobothnian and Lapland regional economies rely on tourism and are even more dependent on tourism as a source of employment (VisitFinland, 2020a). Åland is an autonomous region of Finland with the highest share of its population employed in tourism ( $14 \%$ compared with $5.6 \%$ in Lapland) (see section on Åland below). Tourism in Finland is characterized by strong dependence on domestic visitors with regional variations and the exceptions of South Karelia and Lapland, which rely more on inbound tourism ( $59 \%$ and $54 \%$, of their total tourism consumption derives from inbound tourism).

Regional economic accounts for 2000 to 2016/2017 are available from Statistics Finland's database in the National accounts section; tourism accounts for 1995 to 2007 are also available in the same section. However, more recent tourism statistics are currently provided by Visit Finland's Statistics Service Rudolf, available from the VisitFinland website (VisitFinland, 2020). This database contains the following datasets, most notably Regional tourism accounts (available for 2013 to 2018). What is normally called 'tourism consumption' is called 'tourism demand' in the Finnish tables, and is divided into five tables (inbound, domestic, domestic leisure ${ }^{6}$, other domestic and inbound share of total tourism demand).

\begin{tabular}{|l|c|c|c|}
\hline & 2015 & 2017 & 2018 \\
\hline Total tourism demand in Finland (billion €) & 13,754 & 15,104 & 15,691 \\
\hline Inbound tourism demand (billion €) & 3,588 & 4,564 & 4,851 \\
\hline Domestic tourism demand (billion €) & 10,166 & 10,540 & 10,840 \\
\hline $\begin{array}{l}\text { Tourism value added as a share of GDP (at basic prices, } \\
\text { \%) }\end{array}$ & 2.5 & 2.7 & 2.7 \\
\hline $\begin{array}{l}\text { Value added generated by tourism demand (million } € \\
\text { incl. employment expenses) }\end{array}$ & 4,477 & 5,228 & 5,401 \\
\hline GDP at basic prices (million $€$ ) & 180,186 & 195,143 & 202,334 \\
\hline Employment in tourism, persons & 137,400 & 138,900 & 142,100 \\
\hline $\begin{array}{l}\text { Tourism-related employment in tourism industries (No. } \\
\text { persons employed) }\end{array}$ & 62,700 & 59,200 & 61,00 \\
\hline $\begin{array}{l}\text { People employed in tourism industries as a percentage } \\
\text { of total employment }\end{array}$ & 5.5 & 5.4 & 5.4 \\
\hline
\end{tabular}

Table 1. Tourism Satellite Account Finland.

Finland has additional studies using other methods to study the economic impact of tourism. Paajanen (1997) worked on a method of economic impact analysis for tourism in the years around the turn of the millennium. That method was designed for local/regional environments where the analysis primarily served local tourism planning. In addition, Metsähallitus and Parks and Wildlife-the authority for managing national parks and other state-owned protected areas in Finland-estimates the socio-economic benefits of visits to national parks and protected areas. The authority does not use RTSAs for this purpose, but rather, a model originally developed for the US National Park Service and based on a visitor monitoring system and surveys (for more information, see OECD, 2016). Tohmo (2018) estimated the value of economic

6. Compensated business trips and free use of personal residences. 
tourism in Central Finland with a regional input-output analysis. It is interesting that in recent years (since 2011), Finland has systematically published cultural satellite accounts that are also relevant to TSAs (Statistics Finland, 2020a). The results show that the share of GDP from cultural activities was 3.3\% in 2018, which had decreased slightly (by $0.1 \%$ ) from 2017.

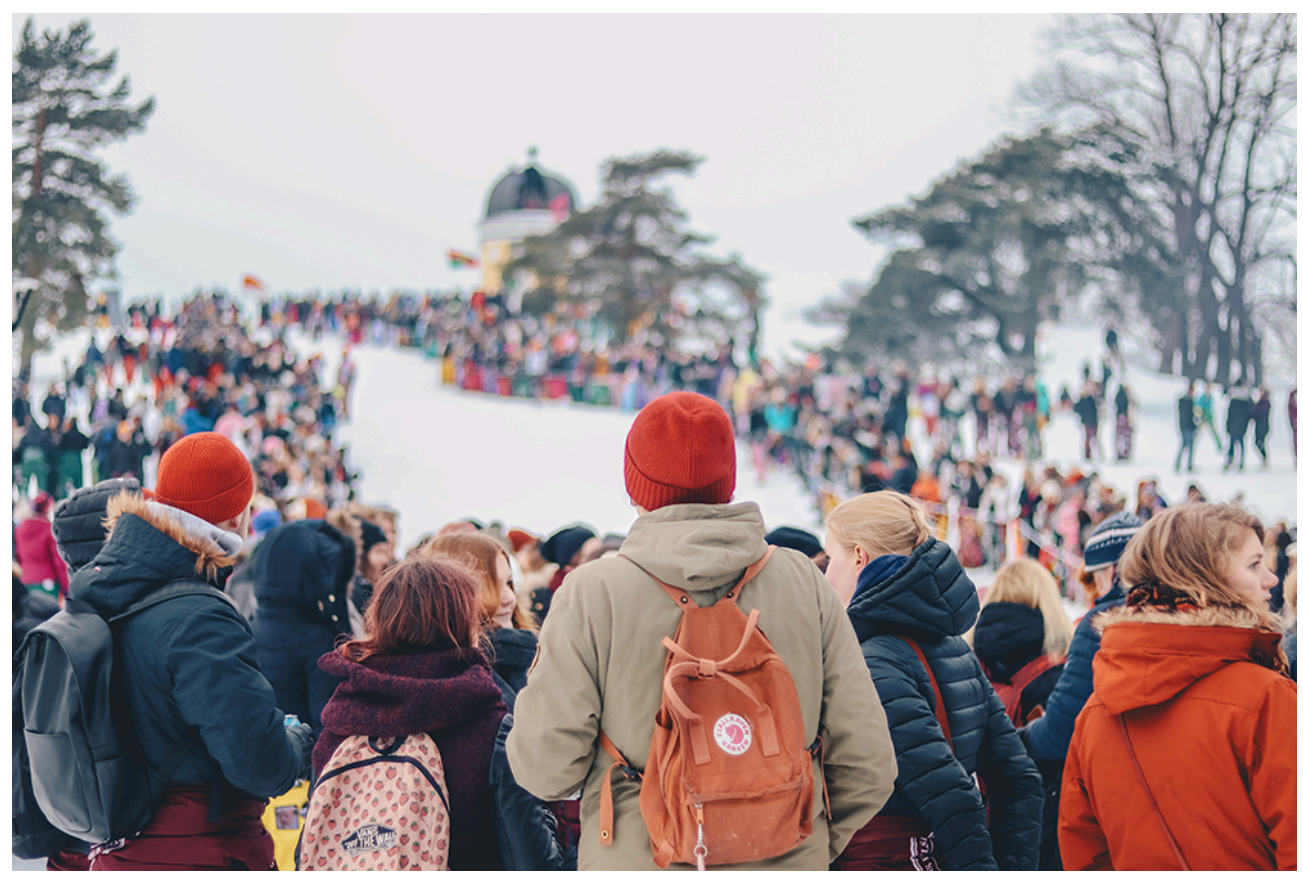

People gathering in public events in Finland.

Photo: Unsplash.com

\subsection{Iceland}

The rapid development of tourism in Iceland has triggered rapid growth in the tourism sector and increased interest in quantifying the economic benefits and $\operatorname{costs}^{7}$ of tourism for the Icelandic economy as a whole (Jóhannesson, 2010). In its resolution on tourism for the years 2011 to 2020 , the Icelandic parliament set as goals increasing the profitability of the sector, systematic development of tourism destinations and products, enhancing professionalism, quality and safety and the maintenance of Iceland's uniqueness as a tourism destination (Rögnvaldsdóttir, 2014).

Between 2008 and 2011, Statistics Iceland published several TSAs for the reference period 2000 to 2009, all at the national level. In 2015, a project between the Icelandic Tourism Research Centre and Statistics Iceland resulted in new TSA data that were published for 2009 to 2013 (see Frent, 2015, 2018). Since then, TSA data have been calculated for each year and are available from the Statistics Iceland database (with the most recent data currently available for 2017). Owing to changes in data sources and some changes in concepts and standards, the new set of TSAs published after 2009 is not fully comparable with the older set of tables.

In addition, Frenț (2014a) calculated TSA aggregates for Iceland as a whole (tourism gross fixedcapital formation and tourism collective consumption). According to these estimations, before the impacts of the COVID-19 pandemic were felt, the tourism industry had become a larger contributor to the Icelandic economy than the fishing industry, which is traditionally one of the core economic activities of Icelanders (Frenț, 2018).

7. Mandle (2018) points out that costs of increased tourism to Iceland are noticeable in at least four areas: increased crime, degradation of roads and highways, damage to natural attractions and increased housing costs. 
At the regional level, Rögnvaldsdóttir $(2014,2016)$ studied available tourism data for Pingeyjarsýslur (now Norðurping), a region in northern Iceland with a population of approximately 4,800 , with a focus on the effects of the inbound tourism of foreign visitors but did not take domestic tourism into account. Rögnvaldsdóttir consulted a range of available statistics for her studies, and conducted company interviews and an inbound visitor survey in the region during from 2013 to 2015 . She estimated tourist numbers and overnight stays in the region, total turnover by tourism industries and tourist consumption in the region, as well as the indirect effects of tourism, employment and municipal revenues.

Rögnvaldsdóttir (2014) notes that according to Eurostat's NUTS classification, the number of separate entities in Iceland is small. This is mainly due to population size-other European countries have a higher population density than Iceland, which has prompted a more detailed division of other territories into individual units. In Iceland, by contrast, the NTUS-3 classification only distinguishes between the capital area around Reykjavík and the rest of the country. At the LAU1 level, there are eight statistical units (regions) in Iceland and 74 municipalities at the LAU2 level. These differences in statistical classification between Iceland and the rest of Europe (including other Nordic countries) have considered in determining the appropriate geographic level for RTSAs to be calculated. The Tourist Board of Iceland has recommended distinguishing between five main tourist destination regions in Iceland (see Rögnvaldsdóttir, 2014).

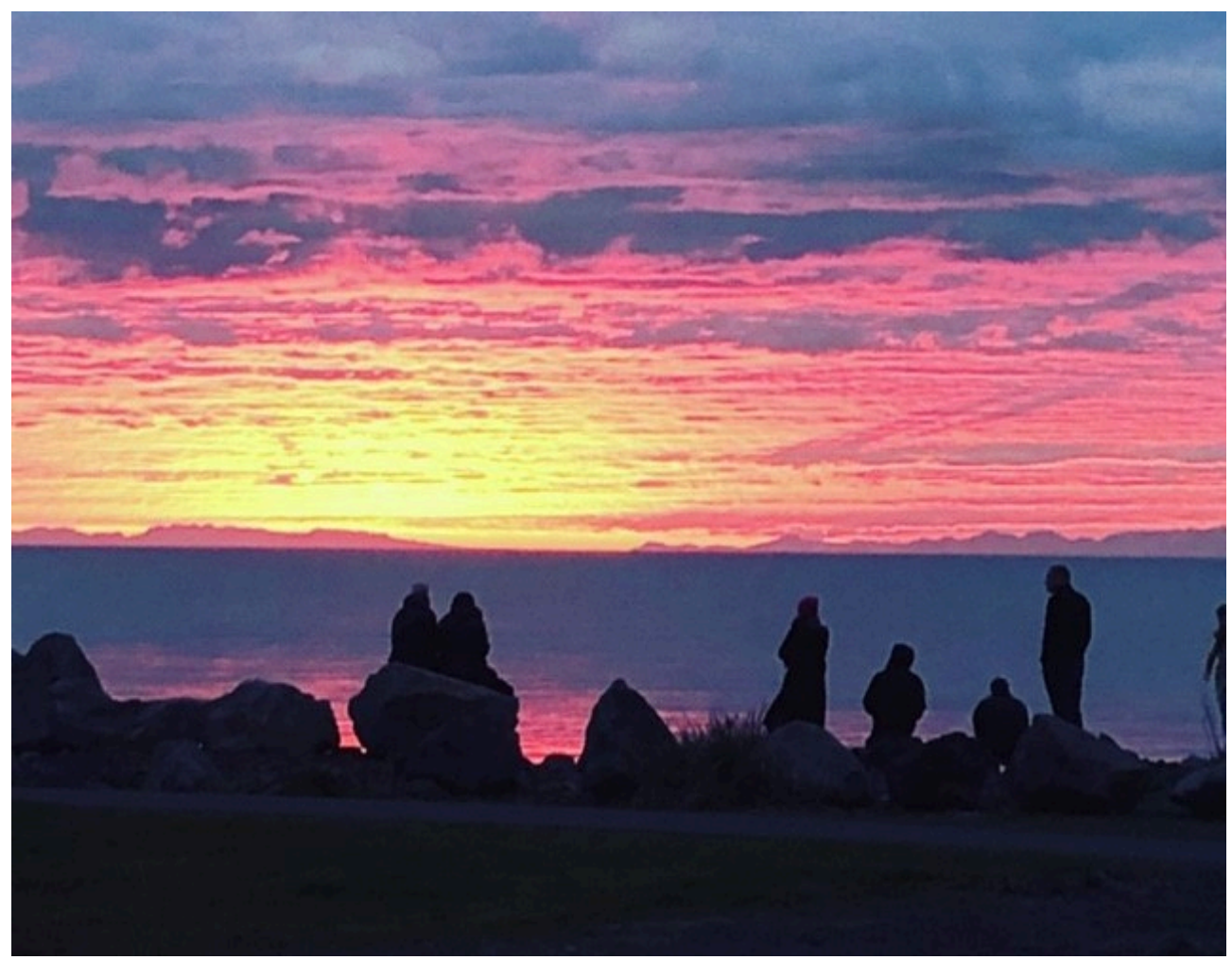

Sunset viewers in Seltjarnarnes, Iceland.

Photo: Anna Karlsdóttir

An overview of tables showing tourism statistics currently available on the online database of Statistics Iceland can be found in the Appendix. More specific statistical studies can be found on the website of the Icelandic Tourism Board, which is also responsible for the tourist survey. However, in recent years, analyses of economic prospects have relied more heavily on banks' analytical units (Icelandic Tourism Board, 2020). As noted above, where data are available at the regional level, this has been highlighted in bold. In her study, Rögnvaldsdóttir (2014) concluded 
that the lack of regional data 'makes statistical analysis of tourism at the regional level in Iceland difficult and expensive'. This conclusion still seems to hold. Frenț $(2013,2014 b)$ makes a series of recommendations to improve Icelandic statistics to meet international standards and provide better information on the tourism sector in Iceland.

In addition to the datasets (in the Appendix), Statistics Iceland has also published the results of a travel survey conducted by the Tourism Council from 2007 to 2018. Indicators include the number of tourists according to gender, age and household income, number, average length and main purpose of inbound and outbound trips, and types of accommodation. The survey was conducted among residents of Iceland only, so it does not include foreign tourists. Only a few of the available datasets include regional information (e.g. destination of inbound trips by region, domestic trips in each season, region and unit, type of transport for domestic trips in each season).

Statistics Iceland has published the number of people employed in the capital region and the rest of the country in workplaces such as hotels and restaurants, and for the whole country, in what it designates 'characteristic tourism occupations'. Information on the numbers of employees each month are available from 2008 to 2020 in transport, accommodation and restaurants, motorized vehicle rentals, leisure and sport equipment rentals, travel agencies, travel planners and other booking services (Hagstofa Íslands, 2020). Owing to the unexpected cessation of tourism due to the COVID-19 pandemic, the Icelandic Tourism Council, in co-operation with KPMG, conducted a special analysis of the financial state of the tourism industry at the end of 2019 (Iceland Tourism Board \& KPMG, 2020). That analysis revealed a rather bleak state of affairs in many tourism enterprises, declining economic returns from tourism and increased debt rates of larger as well as small-to-medium-sized enterprises in the tourism industry. A resurgence of tourism, and hence income and jobs, remains uncertain.

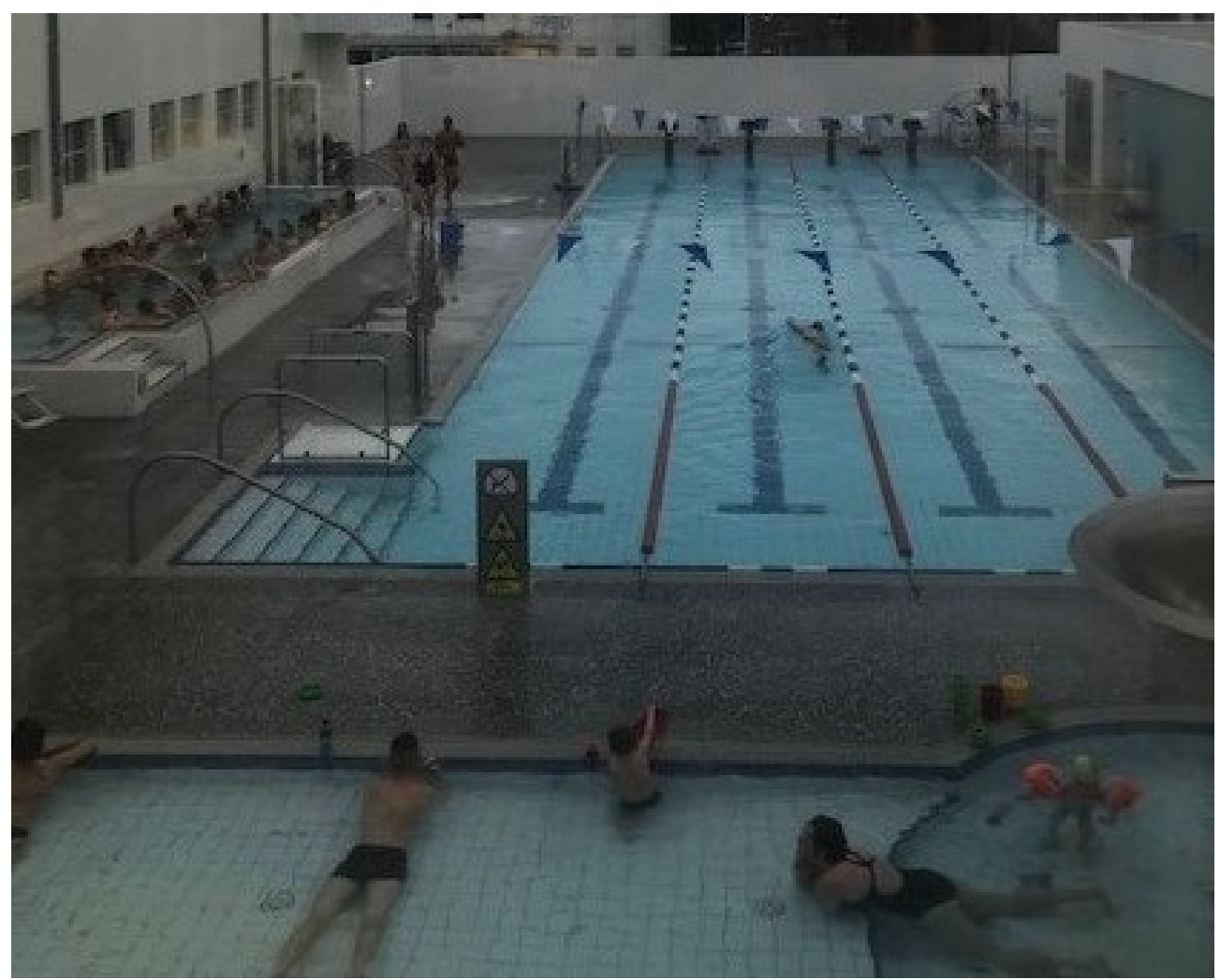

Pool in Reykjavík, Iceland.

Photo: Anna Karlsdóttir 


\subsection{Norway}

Compared with other countries, Norway implemented international guidelines on the development of TSAs relatively early. The Statistical Office of Norway published TSAs from 1988 (Brændvang et al., 2001). Since then, several revisions of the national accounts system have been implemented, so the TSAs are not fully comparable over time. They are currently consistent with the national accounts system, aligned with international TSA standards and revised on an annual basis (Statistics Norway, 2019).

The Norwegian TSA builds on statistics from different sources, including Structural Business Statistics, accounting statistics, trade statistics, household consumer surveys, tourist expenditure surveys and labour statistics. The TSA takes stock of tourism consumption by domestic tourists (residents of Norway) and inbound tourists (non-residents of Norway). Business travel is also taken into account. The Norwegian TSA quantifies the supply of a variety of characteristic tourism products, in addition to output, value added, gross fixed-capital formation and employment in tourism industries (Statistics Norway, 2019).

Parts of the TSA concerning regional output, value added and employment in tourism industries are also published in some years. In 1997 and 2007, Statistics Norway published tourism consumption data for regions (Statistics Norway, 2019). In addition, the Norwegian Institute for Urban and Regional Research, Statistics Norway and the Institute of Transport Economics conducted a pilot project on RTSAs in Norway between 1999 and 2001. The results of this project were published in various reports, including one on the data, concepts, methods, and applications of RTSAs in Norway (Brændvang et al., 2001). In their project, the authors aimed to develop a simple simulation model to construct RTSAs for the Norwegian context. Brændvang et al. (2001) treated each county of Norway as a 'small nation', to which they applied the principles of the national accounts and the national-level TSA. Their study focused on tourist consumption, which was understood to include all consumption in a county by non-residents (i.e. including residents of other counties of Norway). Brændvang et al. (2001) used existing regionalized national accounts for their study and built on the national TSA and tourist surveys. Tourist consumption as measured by the national TSA was broken down to the regional level by product according to various types of keys.

\begin{tabular}{|l|c|c|c|}
\hline & 2016 & 2017 & 2018* \\
\hline Total tourism consumption in Norway (million NOK) & 170002 & 176306 & $186308^{*}$ \\
\hline $\begin{array}{l}\text { Non-residents' share of total tourism consumption in } \\
\text { Norway (\%) }\end{array}$ & 29.5 & 29.8 & $29.7^{\star}$ \\
\hline Annual volume change in total tourism consumption (\%) & 3.3 & 2.2 & $3.7^{*}$ \\
\hline $\begin{array}{l}\text { Resident households' tourism consumption in Norway } \\
\text { as share of households' final consumption expenditure } \\
\text { (\%) }\end{array}$ & 7.1 & 7.1 & $7.3^{*}$ \\
\hline $\begin{array}{l}\text { Value added in the tourism industries as share of GDP } \\
\text { Mainland Norway (\%) }\end{array}$ & 4.4 & 4.3 & $4.2^{\star}$ \\
\hline $\begin{array}{l}\text { Annual volume change in value added in the tourism } \\
\text { industries (\%) }\end{array}$ & 1.4 & 1.4 & $2.6^{*}$ \\
\hline $\begin{array}{l}\text { Employment in the tourism industries' share of total } \\
\text { employment in Mainland Norway. Man year, full time } \\
\text { equivalents, employees and self-employed (\%) }\end{array}$ & 7.1 & 7.1 & $7.1^{*}$ \\
\hline
\end{tabular}

* Premilinary figures

Table 2. Overview of outcomes from Norwegian national TSA 2020 (SSB, 2020). 
Currently, the Statistics Norway database contains a section on 'Tourism Satellite Accounts' with the number of available datasets in 2018 last updated in 2020. Only two are available at the regional (county) level.

In addition to the above-mentioned datasets, Statistics Norway has published additional data and statistics in a section on 'Tourism', some of which are available at the regional (county) level. These encompass the following measures: nights in each type of accommodation-hotels, guesthouses and campsites-by guests' country of residence, as well as structural business statistics on hotels and restaurants and accommodation and food service activities.

The Statistics Norway database also contains a section on 'Regional accounts' with indicators such as the number of people employed in each sector, gross fixed-capital formation or value added at current basic prices. Nonetheless, tourism is not included as a separate industry or sector in these tables. Only tourism-related sectors such as accommodation and food service activities appear (see an overview of the tables in the Appendix).

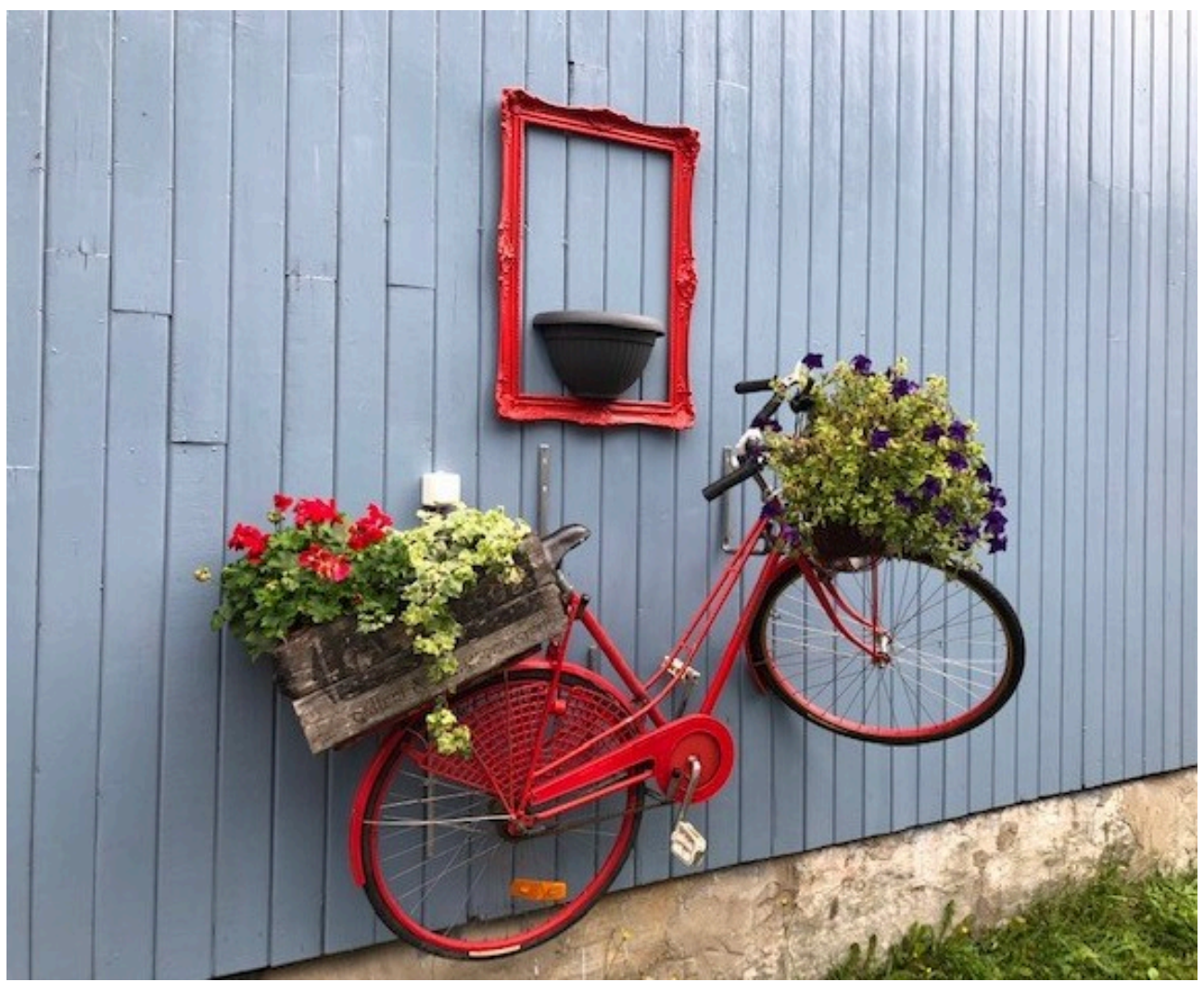

Decoration on the building in Mosjöen town, Norway.

Photo: Anna Karlsdóttir

\subsection{Sweden}

The first TSA for Sweden was calculated in 1985, focusing solely on the supply side of tourism (Nordström, 1996). Later on, Nordström (1996) estimated consumption expenditures for the years 1992 to 1993, but focused only on internal visitors to Sweden. Statistics Sweden then started to produce national-level TSAs in 1995 at the request of the Swedish Tourist Authority. The authority wanted to have a more precise estimate of the contribution of tourism to the Swedish economy than the national accounts could deliver. Since the first publication of TSAs, some methodological changes have been implemented, partly in response to changes in international guidelines. 
The Swedish Agency for Economic and Regional Growth (Tillväxtverket) is currently in charge of tourism industry issues in Sweden. On its behalf, Statistics Sweden has published national-level estimates concerning issues such as employment by industry and tourism value added to GDP on an annual basis since the mid-1990s (Tillväxtverket, 2019a). These are integrated with the Swedish national accounts system in line with international TSA standards. Accommodation statistics (including information on the number of nights spent and revenue from the accommodation sector) have been published on a regional (Län) level in several publications (for instance, see Tillväxtverket, 2019b). Full regional TSAs are not currently available, but Kronenberg et al. (2018) recently published a tourism input-output analysis for the Jämtland region (see also Junkka, 2009 for an early RTSA study on Jämtland). Tillväxtverket is working on further harmonization of touristic consumption data gathered from traveller surveys, thereby facilitating future work on RTSAs (correspondence with Frederik Junkka, 2019). This means that some calculations have been modified in the 2019 TSA and consumption now includes taxes (Tillväxtverket, 2020b). Open data is available in ten tables from 2019, 2018 and 2017 (Tillväxtverket. 2020).

\begin{tabular}{|l|c|c|c|}
\hline & 2017 & 2018 & 2019 \\
\hline Total tourism demand in SE (million SEK) & 278567 & 298842 & 306251 \\
\hline Inbound tourism demand (million SEK) & 95718 & 100525 & 99770 \\
\hline Domestic tourism demand (million SEK) & 182849 & 198317 & 206481 \\
\hline $\begin{array}{l}\text { Tourism value added as a share of GDP (at basic prices, } \\
\text { \%) }\end{array}$ & 2.5 & 2.6 & 2.5 \\
\hline Tourism direct gross value added (TDGVA) (million SEK) & 83465 & 86641 & 148501 \\
\hline Tourism Direct Gross Domestic Product (million SEK) & 4625094 & 4828306 & 4463292 \\
\hline Employment in tourism, persons & 284400 & 287000 & 291911 \\
\hline
\end{tabular}

Table 3. Overview of outcomes from Swedish national TSAs 2017, 2018 and 2019. Source: Tillväxtverket \& SCB, 2020. 


\subsection{Faroe Islands}

TSAs have not yet been published for the Faroe Islands. On the database of the Statistical Office of the Faroe Islands, a limited range of tourism statistics are available under the category of 'Accommodation'. These consist of several datasets on overnight stays by type of accommodation, region, purpose and/or country of residence (Hagstova Forøya, 2020). These are the only specifically tourism-related statistics that could be identified besides more general calculations of the export value of services in Búskaparfrágreidingar, the quarterly economic outlook reports by the Economic Council of the Faroe Islands (i.e. Búskaparáðið, 2018).

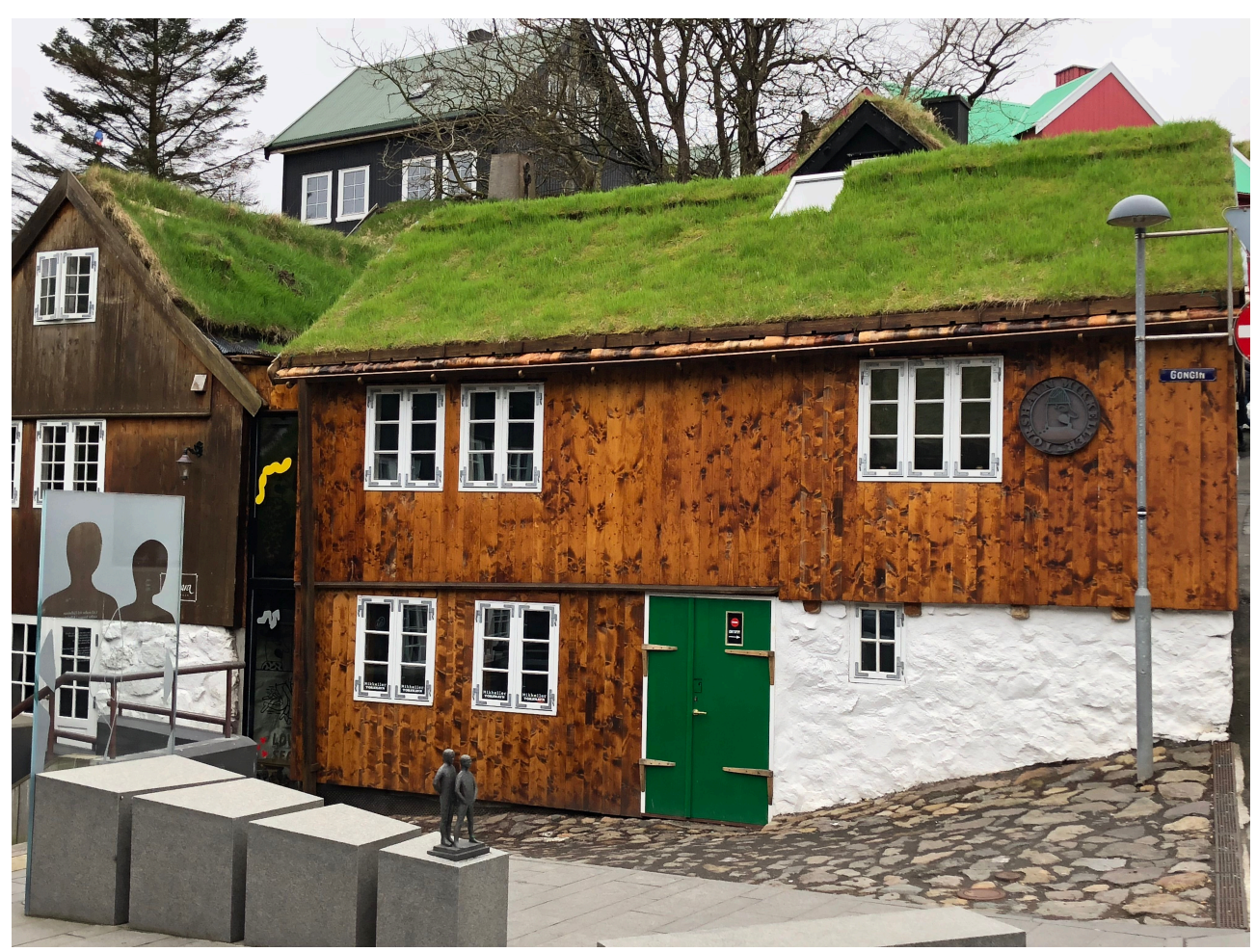

"Gongin" street gentrification and renovation of old building in Tórshavn, Faroe Islands.

Photo: Anna Karlsdóttir 


\subsection{Greenland}

Greenland has not yet published a TSA account (VisitGreenland, 2017). Nonetheless, the Statistics Greenland database contains a 'Tourism' section with statistics that offer insights into the sector; these are summarized below. Only the datasets on 'overnight stays' provide information at the regional level (highlighted in bold). Statistics on flight passengers and cruises are available for all individual airports and ports, respectively, in Greenland.

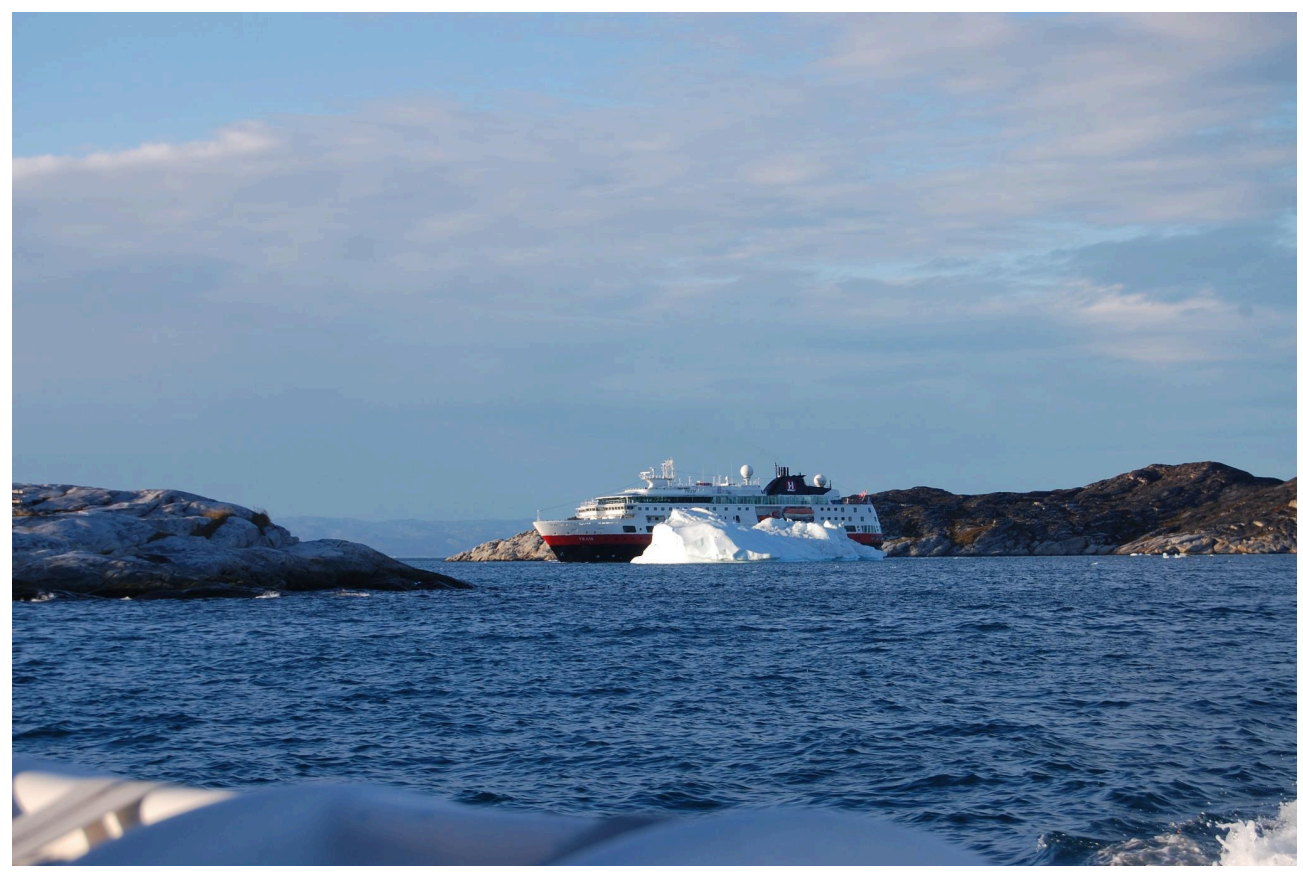

Cruise ship by Iceberg in Ilulissat, Greenland.

Photo: Anna Karlsdóttir

\section{8 Åland}

Statistics and Regional TSAs for Åland are included in the database of Statistics Finland and VisitFinland (see section on Finland above). In addition, the Statistics and Research Åland (ÅSUB) database provides several tourism-related datasets, which are summarized below. Every 5 years, ÅSUB also publishes a report on the socio-economic role of tourism in Åland. This includes information and data on the consumption and expenditure of different tourist groups, as well as calculations of the share of tourism in Åland's economy and its effect on employment. The latest report is available for 2018 ( $\mathrm{S} S U B, 2019$ ).

Åland has also published SAMs for the years 2007, 2010 and 2015, in which tourist expenditure is broken down by commodity for two groups: domestic (mainland Finnish) tourists and foreign tourists. Tourist expenditure includes expenditure on board Åland-owned cruise ships on their way to and from Åland, as well as their land-based consumption. The SAMs are used as a central part of the database for a CGE model for Åland that has been used to analyse tourism's contribution to the local economy.

In addition to the 5-year studies, Statistics Åland publishes an annual calculation of tourism's share of GDP at factor prices as a part of the national accounts statistical leaflet. ÅSUB also publishes a monthly indicator of wages and turnover for tourism in its statistical databases. The annual and monthly calculations use the results of the quinquennial studies. 


\begin{tabular}{|l|c|c|c|}
\hline & 2015 & 2017 & 2018 \\
\hline Total tourism demand (million €) & 341 & 414 & 421 \\
\hline Inbound tourism demand (million €) & 128 & 155 & 157 \\
\hline Domestic tourism demand (million €) & 212 & 260 & 264 \\
\hline $\begin{array}{l}\text { Tourism value added as a share of GDP (at basic prices, } \\
\text { \%) }\end{array}$ & 15.6 & 19.3 & 19.7 \\
\hline $\begin{array}{l}\text { Value added generated by tourism demand (million } € \\
\text { incl. employment expenses) }\end{array}$ & 158 & 198 & 200 \\
\hline GDP at basic prices (million $€$ ) & 1,177 & 1,189 & 1,176 \\
\hline Employment in tourism, persons & 2,600 & 2,600 & 2,650 \\
\hline $\begin{array}{l}\text { Tourism-related employment in tourism industries } \\
\text { (number pers. employed) }\end{array}$ & 2,000 & 2,050 & 2,100 \\
\hline
\end{tabular}

Table 4. Tourism Satellite Account Åland. Source: TSAs Finland, VisitFinland, 2020. 


\section{Expert statements on TSAs-advantages and disadvantages}

By Jie Chiang, Katarina Fellman and Jouko Kinnunen, edited by Anna Karlsdóttir.

\subsection{Common Regional TSA accounting analysis and method for the Nordic countries}

Measuring tourism economic effects is in general a complex procedure because it requires collecting data from both supply and demand services related to tourism. With TSA it is possible to compare different tourist segments performance and calculate the ratio between demand and supply to obtain the direct value added for tourism. However, measuring the effect of tourism on a lower aggregation level (e.g. regional level) represents a more demanding procedure than measuring at national level. If the same data sources are used for the measurement of tourism at national level, the results of a regional analysis may be incorrect.

Compared with other models, satellite accounts actually use accounting methods; they are used for not only tourism, but also transport, health, culture and the environment. The advantages of satellite accounts are that they clearly supplement national accounts and provide detailed accounting for specific areas. A disadvantage should also be mentioned, which is that TSA work is clearly costly and requires a large amount of data. Concerning the final point on RTSA methods, the report has provided a detailed description of two approaches: top-down and bottom-up. In relation to the methods and approaches in developing the Nordic RTSA. While Jie Chang our Denmark expert prefers the bottom-up method, as it provides a more detailed and concrete description of tourism statistics and development, our Åland and Finland experts Jouko Kinnunen and Katarina Fellman argue for the necessity to speak for dual approach, both national top-down studies, and whenever necessary and feasible, region-specific studies that follow as much as possible the national guidelines and solutions. However, they also argue, that these RTSAs should be allowed to deviate in the issues that are of upmost importance to the region. Every country must decide on an approach according to data availability.

Nordic countries appear to have experienced different processes in developing RTSAs. However, except for some regions like the Faroe Islands and Greenland, all the Nordic countries have developed RTSAs with varying frequency. It would be nice to see what RTSA tables are available from each country and to compare their results. 


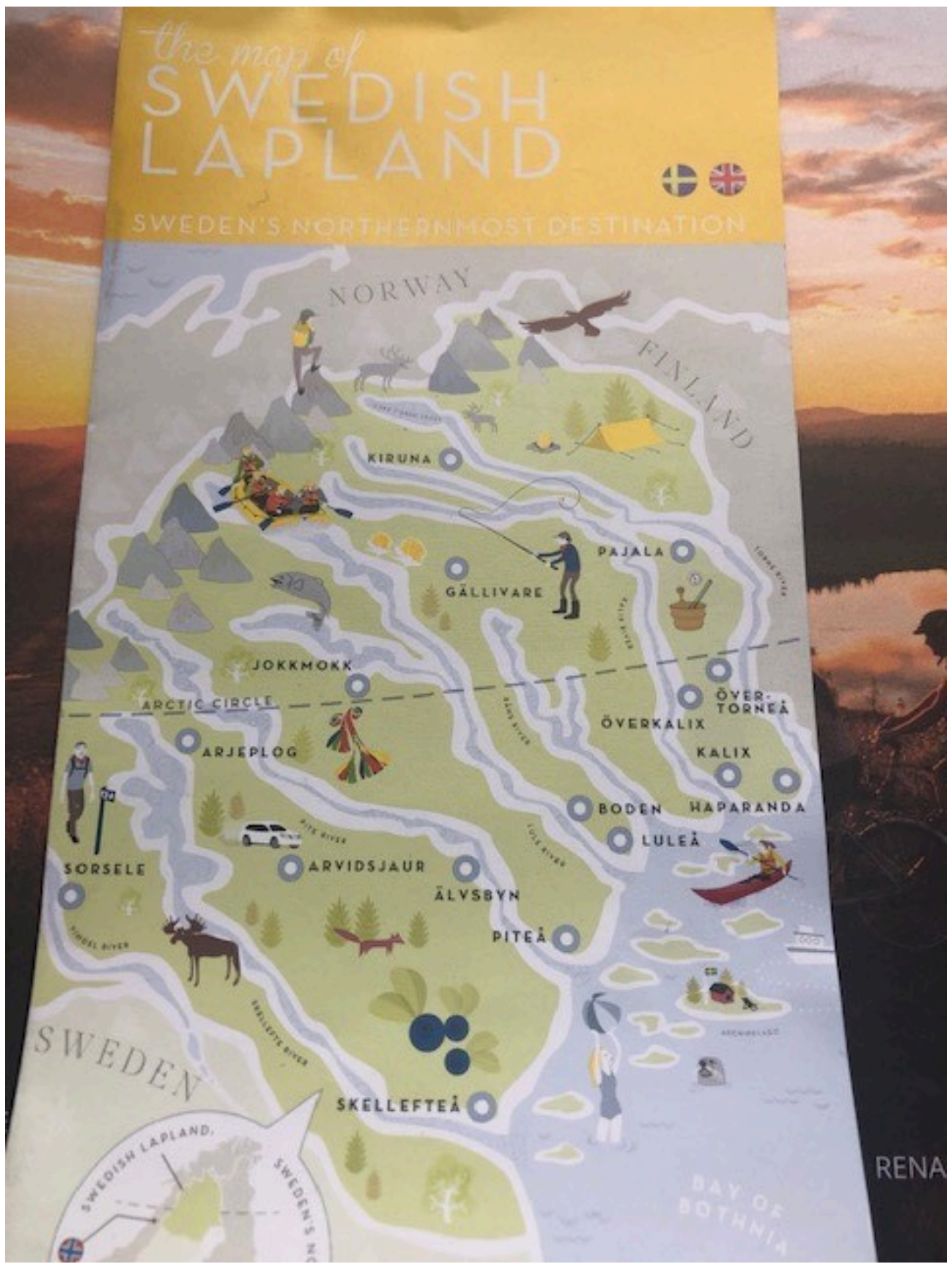

The map of Swedish Lapland.

Photo: Anna Karlsdóttir

\section{Prospects and different approaches for developing regional TSAs}

While there is general agreement regarding benefits that a TSA can provide in analysing tourism, there is less clarity regarding the most appropriate structure of such accounts. It is worth mentioning that the construction of a TSA has potentially significant implications, both during initial construction and for ongoing maintenance.

Regional accounts are needed, together with the national TSA as a framework for successful compilation of accounts from the Åland perspective. However, from experience we know that the national initiatives may not be fully suited for region-specific studies. There are important differences starting from data coverage (e.g. which establishments are included) and methods 
(e.g. how second-home usage is taken into account) between the national Finnish and regional Åland tourism statistics. The national methods should be defined in such a manner that enables flexibility in the definitions and coverage. For example, the number of typical industries that can have a share of tourism should be as large as possible to cater for regional idiosyncrasies.

Each Nordic country has its own national accounts and regional production accounts. It would be nearly impossible to have one unified system for the Nordic RTSAs; therefore, producing independent RTSAs is the best option. However, there may be ways to merge some of core RTSA numbers into one spreadsheet for comparison.

As a starting point for this project, RTSAs for the Nordic Countries were to have a unified definition of tourism. For example, what should be included in the tourism statistics? Should both domestic and inbound same-day visitors be included in the RTSA? If so, there must be a specific definition of domestic same-day visitors (e.g. Are they from across regional borders? How long should they be away from home?).

For which geographical level should RTSAs be compiled? Should it be NUTS-2, NUTS-3 or LAU2 (NUTS 5)? As one of the main objectives for the RTSA project is to describe tourism development in the regional economy and tourism's contribution to the regions, some important tourism data are required (described in next section). We suggest that the suitable geographical level for the Nordic countries is the NUTS-2 level. If the most disaggregated level, such as municipality, is used, much work will be required to compile the data. For future work we should primarily concentrate in each country on the NUTS level for which necessary regional accounts exist.

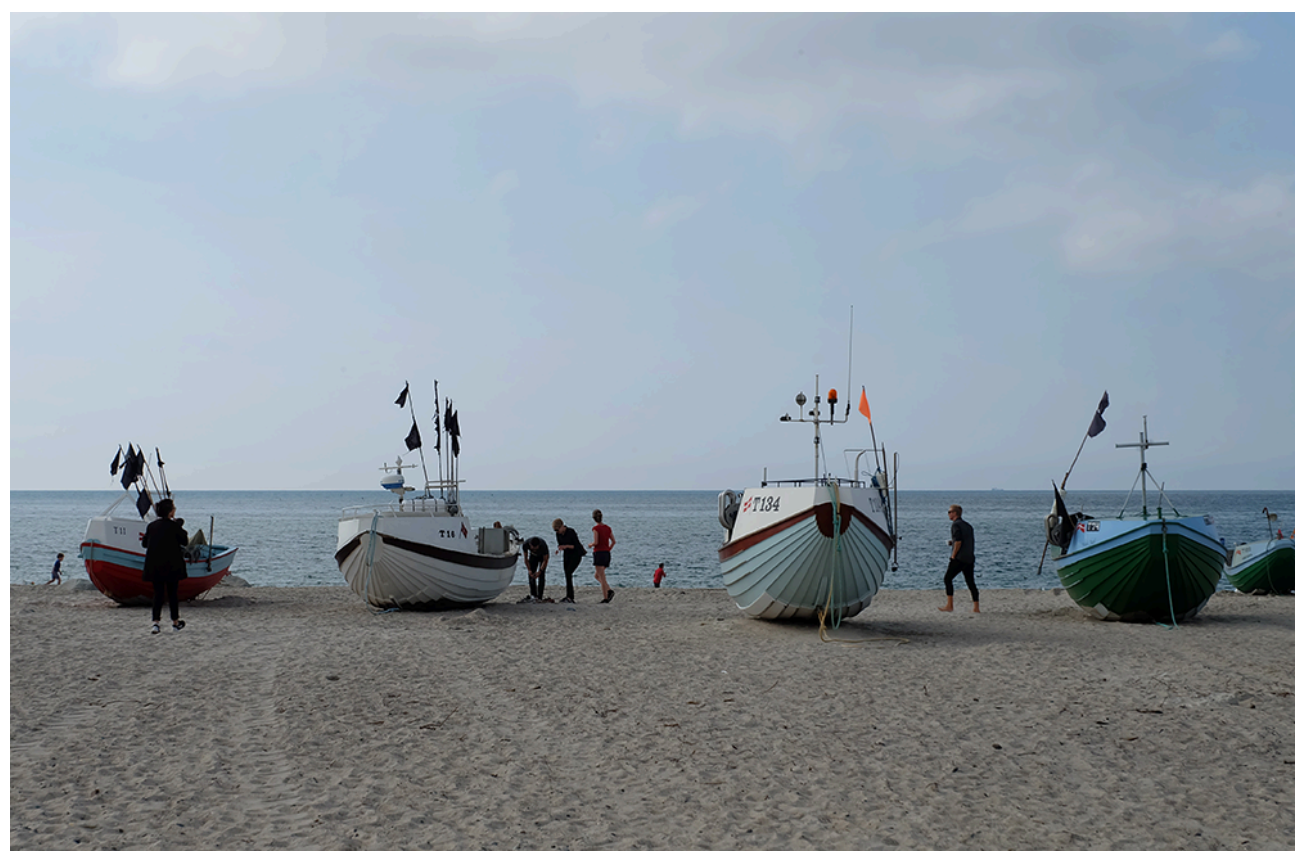

Fishing activities in Denmark.

Photo: Johanna Feuk Westhoff

\section{Tourism products-country-specific products?}

Which tourism products should be included in the project? Should there be a unified list of tourism products? As we all know, each country has specific tourism products. For example, in Norway, Sweden and Finland, winter ski tourism is an important part of tourism. However, in Denmark and other regions, ski tourism does not exist. Therefore, ski tourism should be on the list of country-specific tourism products. 


\section{Tourism industries}

Is it possible to have a unified list of tourism industries, like the UNWTO list 10 important industries?

There is also the issue of cross-checking, as the Nordic countries are neighbours. The Danish inbound tourists from Norway, Sweden and Finland must be outbound tourists from these countries. Is it possible to cross-check after the Nordic RTSA tables are created?

The Nordic RTSAs have some differences, for example in the treatment of business tourism. In the future Nordregio could take as a task to report those figures and aspects for tourism that can be found from all the regions. In addition, Nordregio could develop initial estimates e.g. for tourism's share of regional GDP for the regions that do not have official RTSAs compiled yet (i.e. Sweden). The results can be presented in terms categories, which masks the lower reliability of estimated results.

\subsection{Possible next steps in developing RTSAs in the Nordic Region}

If we were to develop a common and comparable RTSA for the Nordic region, we should, in general, follow the UNWTO/OECD/Eurostat document (UNWTO, 2008) for the seven key TSA tables. However, the UNWTO TSA tables focus on tourism consumption by inbound and domestic tourists. In general, the more data can be divided into subgroups with the goal of breaking down more aggregate results into smaller segments, the better. We suggest that we include the numbers of same-day visitors and tourist nights at destinations in different types of accommodations. Therefore, besides TSA Tables 1-4, we should develop TSA Table 1a to show numbers of inbound same-day visitors and overnight tourists, TSA Table 2a for the numbers of domestic same-day visitors and overnight tourists and TSA Table 4a for the number of total (inbound and domestic) same-day visitors and overnight tourists. I recommend breaking these tables down by NUTS-2 region (see map below). That is, if one country has five NUTS-2 regions, then it should have five TSA tables: 1a, $2 a$ and $4 a$, etc. TSA Table 5 should include production accounts for sector and product, and there should be a similar table for each region. TSA table 6 is simply a combination of Tables 4 and 5 . It should be noted that the important indicator from TSA Table 6 is 'tourism ratio of supply'-that is, the share of demand for each tourism product supplied. As tourism demand is normally presented by purchase prices, but tourism supply is normally in basis prices, we also need to transform the supply into purchase prices. This is quite difficult, as most figures for production supply are given in basis prices in the national accounts. In Åland growing problems have been identified with recognizing difference between tourists and local customers for established businesses and surveys conducted among businesses may not be sufficient sources of information. For example, we see a growing role for second-home owners in our tourist interviews. Another problematic group from information gathering point of view are accommodations in private homes, either provided through platform services like Airbnb's or through some other means. All in all, we want to stress the importance of triangulation of information from different sources considering how to address this issue. 


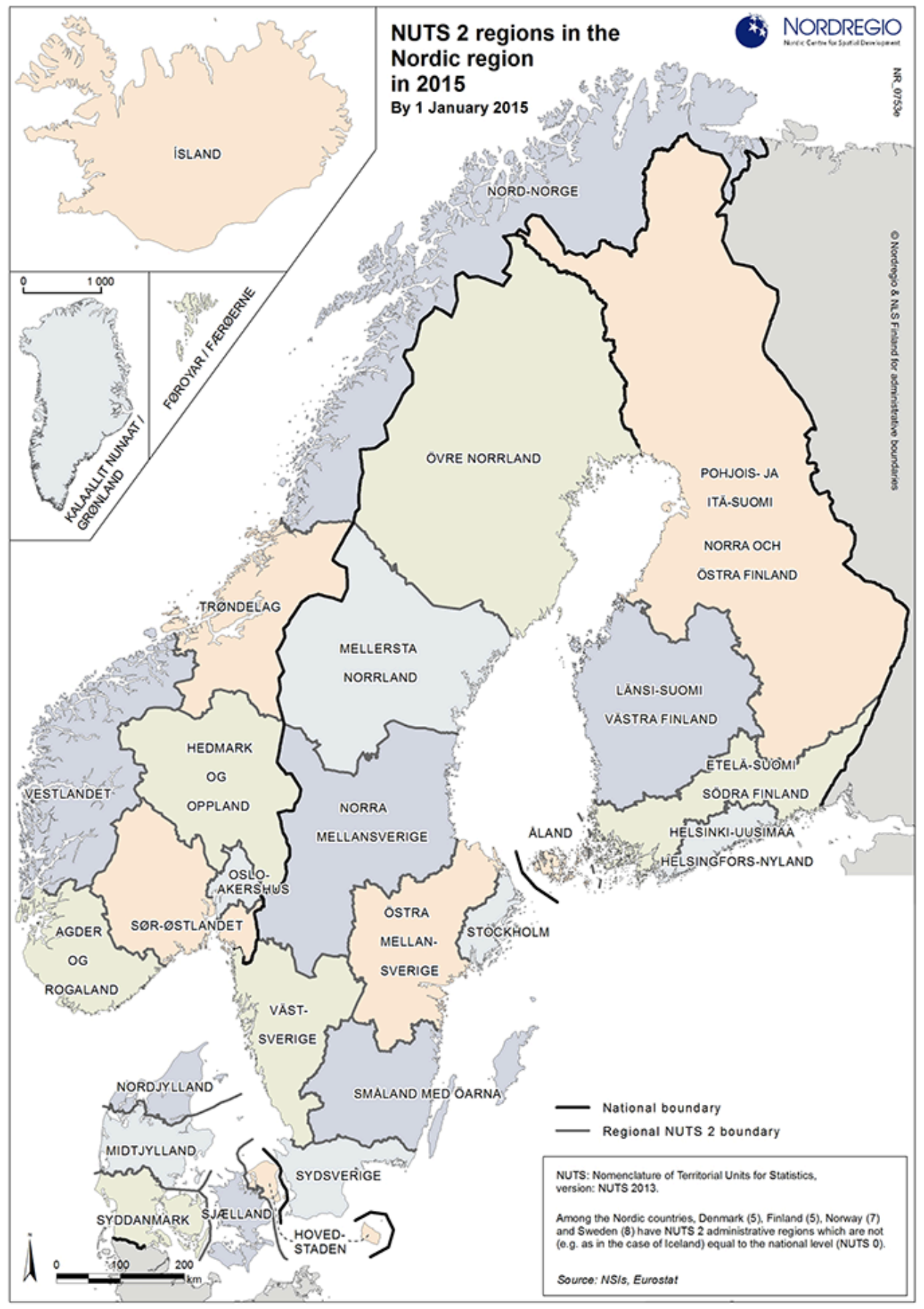

Map 5. Regional NUTS 2 boundaries in the Nordic region.

Source: Designer/Cartographer - Linus Rispling, Nordregio

TSA Table 7 is employment accounts-it is believed that most countries have these numbers, which can be broken down by sector (tourism versus non-tourism sectors) and by gender, education or other factors. Previous reviews have found that most countries have difficulty providing TSA Tables 8 and 9. I suggest that we omit these two tables at present. As we have already added Tables 1a-4a, we do not require TSA Table 10. 


\subsection{Steps for developing a Nordic RTSA}

One question concerns the steps required to develop RTSAs in the Nordic countries. If the short term is defined as 1 year, the medium term as 3-5 years and the long term 7-10 years, then Jie Zhang recommend starting with the short term to construct a single-year Nordic RTSA, and then prepare for the medium and long terms. In other words, even if the work is prepared for a short period, the framework should be prepared for the long term; that is, it should allow the system to be updated in the future. In the case of financial support, it is not possible to update the Nordic RTAS every year; this can maybe be done flexibly every 2-3 years.

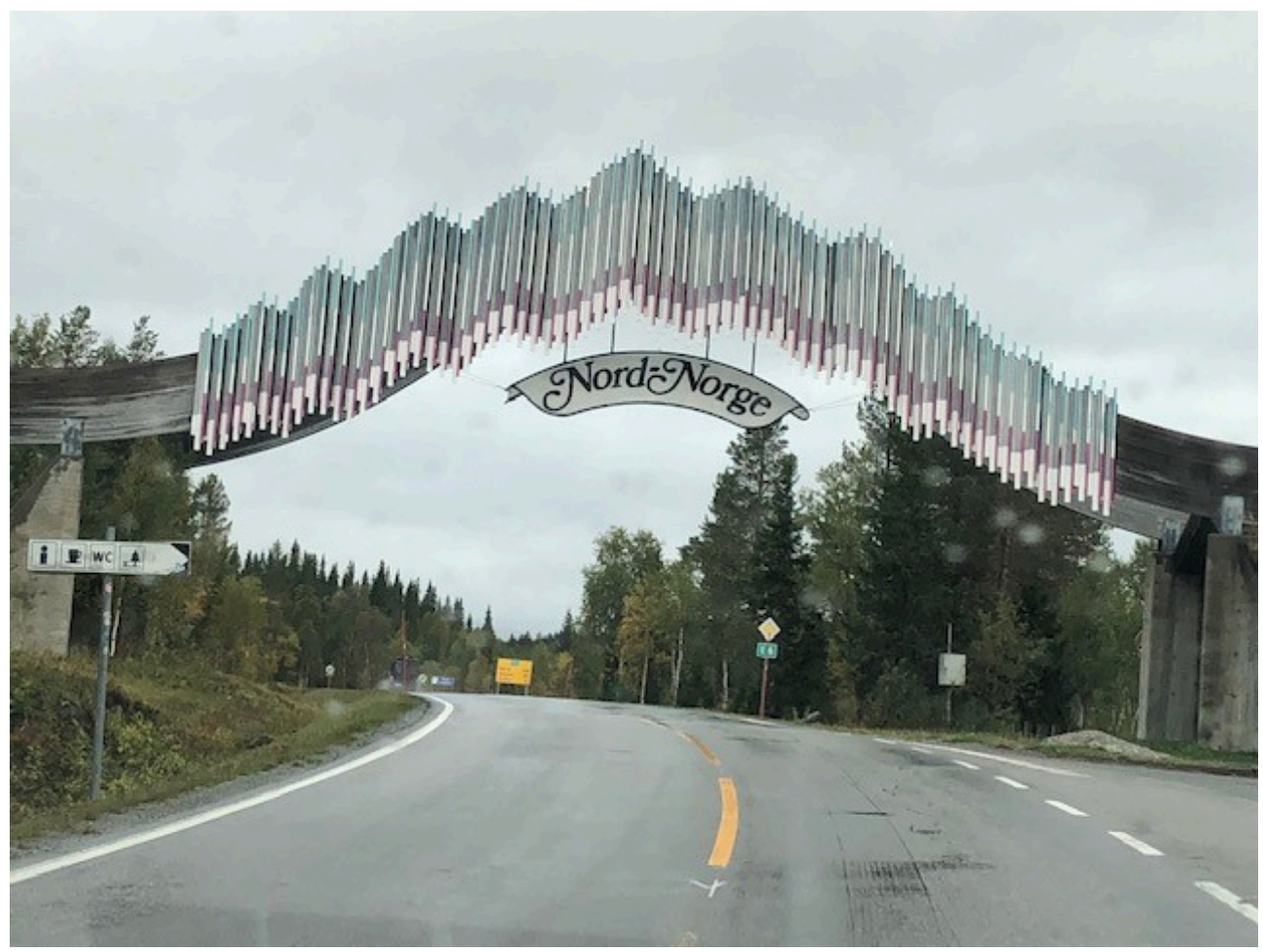

Northern Norway.

Photo: Anna Karlsdóttir

\subsection{Comparable or independent RTSAs in the Nordic countries?}

While the creation of comparable RTSAs is our target, we reckon this is not easy to achieve. The intention would be in helping responsible agencies demonstrate the scale and scope of tourism and aide them in policy planning with a tool with clear value in an accounting and economic modelling sense. As each country has its own national accounts and tourism products-even specific tourism industries-a unified system for the Nordic RTSA will be challenging.

The best option is to establish one or two unified spreadsheets for every country to deliver according to requirements. Other tables should be allowed to differ; for example, there may be different tourism products or industries. Comparison target 1 is 'tourism ratio on supply' in hotels and restaurants, while target 2 can be the share of GDP contributed by tourism in each region.

Cohesive Nordic regional Tourism Satellite Accounts may for now be out of reach other than within limited set of comparisons across countries of regions. Compiling RTSAs is closely related 
to regional accounts and regional input-output tables. The report shows clearly that the data underlying theses statistical products are also needed in the compilation of RTSAs. Therefore, either very close cooperation and (micro) data sharing or outright joining of forces is needed between compilers of main regional accounts and regional tourism satellite accounts. Tourism bodies should e.g. help in guaranteeing that the number of regional tourist interviews is sufficiently large to enable compilation of regional RTSAs. And data gathering is very time consuming and costly, coordination between regional accounting and RTSAs is needed to reach the best possible results with the existing resources. In addition, the national and regional bodies should be involved in lobbying for increasing the resources.

In the future, Nordregio could also gather and publish experiences (and manuals) for different ways of compiling top down RTSAs, which we see as a good way to start creating accounts for the regions lagging behind in publishing accounts. For example, the same methods that are being used in the creation of regional supply and demand tables for CGE models or in the creation of regional input-output tables, starting from national counterparts, can be adjusted to produce the most rudimentary versions of the RTSAs containing production and employment by industry/ product as well as share of GDP. Nordregio could conduct such studies with interested counterparts. Also, the mapping competence of Nordregio should be used in the comparison and surveying of the RTSAs results.

Broader considerations also remain. When implementing analysis of economic impact, it should be possible to illustrate which effects of tourism are particularly important for society and not just for the supply side of the tourism industry (Kronenberg et.al, 2014). This could also include a definition of the sectors that earn the most from tourism (e.g., hotels, real estate, trade) and furthermore the extent to which these industries are important to society (e.g., number of jobs generated, added value, growth development). In this context, it is relevant that the interests of different stakeholders are identified and considered. For this reason, specific key figures and impact indicators for the various interest groups should be established. These important indicators enable stakeholders to control the extent to which the tourism industry contributes to meeting their objectives. While indicators for measuring the profits of private enterprises are set in financial performance measures, the profits look different on the public side (i.e., the municipal area). They, in turn, are more interested in tourism's contribution to taxes, while politicians are primarily interested in gaining the support of the population and potential voters (i.e., the positive attitude of the inhabitants towards tourism).

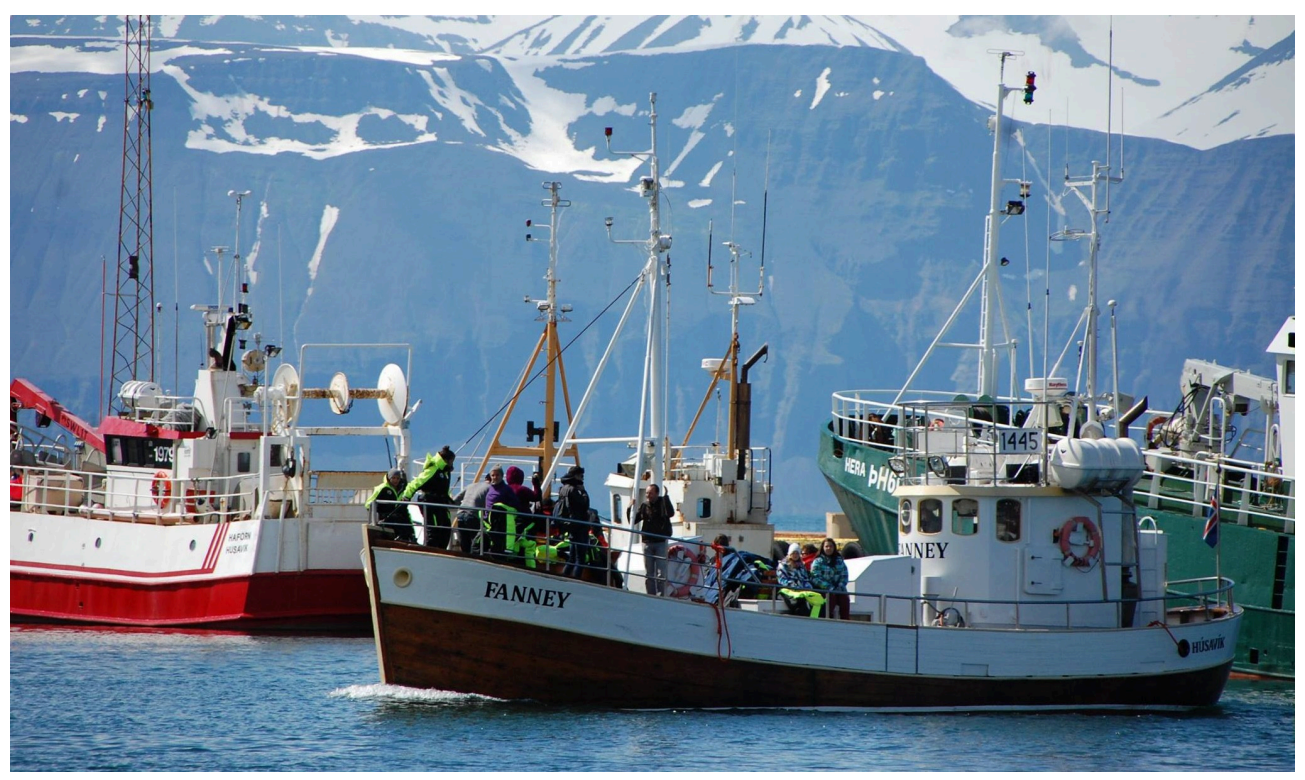

Whale watching in Húsavík, Iceland.

Photo: Anna Karlsdóttir 


\section{References}

Almstedt, Å., Lundmark, L. \& Pettersson, Ö., (2016). Public spending on rural tourism in Sweden. FENNIA-International Journal of Geography, 194(1), 18-31.

Búskaparráðið (2018). Búskaparfrágreiðingar. Retrieved from https://www.setur.fo/fo/setrid/ samstarv/buskaparradid/buskaparfragreidingar/

Brændvang, A. K., Dybedal, P., Johansen, S. and Sørensen, K. (2001). Regional satellite accounts for tourism. Data, concepts, methods and applications, Paper for the 41st European Congress of the E-RSA, Zagreb, August-September 2001.

Cañada, A. (2013). Regional Tourism Satellite Account, Statistics and TSA: Issue Paper Series, Madrid: UN World Tourism Organization.

Chenguang, W., Liu, J., Song, H., Li, A., \& Fui, H. (2019). Developing a Web-based Regional Tourism Satellite (TSA) Information System, Tourism Economics, 25(1), 67-84.

https://journals.sagepub.com/doi/pdf/10.1177/1354816618792446

Dwyer, L., Forsyth, P., and Spurr, R., (2007). Contrasting the uses of TSAs and CGE models: measuring tourism yield and productivity, Tourism Economics, vol. 13, no. 4, pp. 537-551.

Dwyer, L., Forsyth, P., Spurr, R. and Ho, T.V. (2008). Tourism's economic contribution versus economic impact assessment: Differing roles for Satellite Accounts and Economic Modelling, in: A.G. Woodside and D. Martin, Tourism management: Analysis, behaviour and strategy, Wallingford: CAB International, pp. 459-469.

Eurostat (2009). Tourism Satellite Accounts in the European Union. Volume 1: Report on the implementation of TSA in 27 EU Member States, Eurostat: Luxembourg.

Eurostat (2016). Tourism Satellite Accounts in Europe. 2016 edition, Luxembourg: Publications Office in the European Union.

Eurostat (2019). Tourism Satellite Accounts in Europe-2019 edition, retrieved 11.November 2020 from https://ec.europa.eu/eurostat/documents/7870049/10293066/KS-FT-19-007-EN-N.pdf/ f9cdc4cc-882b-5e29-03b1-f2cee82ec59d?t=1575909526000

Eurostat (2020). Environmental Accounts-establishing the links between the environment and the Economy, Retrieved 1.November 2020 https://ec.europa.eu/eurostat/statistics-explained/ index.php/Environmental_accounts_-

_establishing_the_links_between_the_environment_and_the_economy

Fornesbech-Sandberg, M., \& Rich, R. (2019). Turismens økonomiske betydning 2018.

VisitDenmark I samarbejde med CRT, retrieved 11.November 2020 https://www.visitdenmark.dk/ corporate/videncenter/turismens-oekonomiske-betydning

Frechtling, D. C. (2009). Measurement and analysis of tourism economic contributions for subnational regions through the Tourism Satellite Account. Enzo Paci Papers on Measuring the Economic Significance of Tourism, vol. 6, pp. 189-206.

Frechtling, D. C. (2010). The tourism satellite account. A primer. Annals of Tourism Research, vol. 37, no. 1, pp. 136-153.

Frechtling, D.C. \& Smeral, E. (2010). Measuring and Interpreting the Economic Impact of Tourism: 20/20 Hindsight and Foresight, in: Douglas G. Pearce and Richard W. Butler (2010), Tourism Research: A 20-20 Vision, Oxford, England: Goodfellow Publishing.

Frechtling, D. C. (1999). The tourism satellite account: foundations, progress and issues. Tourism Management, vol. 20, pp. 163-170.

Frenț, C. (2013). The economic benefits of tourism in Iceland: Boosting the Icelandic Tourism Satellite Account development-Icelandic Tourism Satellite Account (TSA)-A conformity assessment with United Nations standards for TSA-Part I, Akureyri: Icelandic Tourism Research 
Centre.

Frenț, C.(2014a). The economic benefits of tourism in Iceland. New developments for the Icelandic Tourism Satellite Account: Tourism Gross Fixed Capital Formation and Tourism Collective Consumption, Akureyri: Icelandic Tourism Research Centre.

Frenț, C. (2014b). The economic benefits of tourism in Iceland. Boosting the Icelandic Tourism Satellite Account Development, Icelandic Tourism Satellite Account (TSA)-A Conformity Assessment with United Nations standards for TSA-Part II, Akureyri: Icelandic Tourism Research Centre. Retrieved May 2018 from http://www.rmf.is/en/reports/index/skyrslur-reports/theeconomic-benefits-of-tourism-in-iceland-boosting-the-icelandic-tourism-satellite-accountdevelopment-icelandic-tourism-satellite-account-tsa-a-conformity-assessment-with-unitednations-standards-for-tsa-part-ii

Frenț, C. (2015). The new compilation of the Tourism Satellite Account in Iceland for 2009-2013. Data sources, methodology and results, Akureyri: Icelandic Tourism Research Centre.

Frenț, C. (2018). Informing tourism policy with statistical data: The case of the Icelandic Tourism Satellite Account. Current Issues in Tourism, vol. 21, no. 9, pp. 1033-1051.

Gustavsson, A. (2018). Turisternas möte med lokalbefolkning. Ojämlikhet kontra jämlikhet i ett förändringsperspektiv. I Kolbe, W \& Gustavsson, A. (2018). Turismhistoria i Norden, Acta Academiae Gustavi Adolphi CL, Uppsala: Kunglig Gustav Adolfs Akademien, 33-47.

Hagstova Forøya, (2020). Ferðavinna. Retrieved from: https://hagstova.fo/fo/vinna/ taenastuvinna/ferdavinnalcelandic Tourist Board (2020). Útgefið efni-Gagnabanki. Umfang og áhrif. Retrieved 8.december 2020 from https://www.ferdamalastofa.is/is/tolur-og-utgafur/ utgefid-efni/umfang-og-ahrif?itemCount=-1

Icelandic Tourist Board \& KPMG (2020). Fjárhagsgreining-Staða íslenskrar ferðabjónustu í árslok 2019. 3.December 2020. Retrieved from: https://www.ferdamalastofa.is/static/files/ ferdamalastofa/Frettamyndir/2020/desember/fjarhagsgreining-stada-

ferdathjonustufyrirtaekja-2019.pdf

Ionnades, D., \& Gyimóthy, S. (2020). The COVID-19 crisis as an opportunity for escaping the unsustainable global tourism path. Tourism Geographies, https://doi.org/10.1080/ 14616688.2020.1763445

Jóhannesson, G.Th., Huijbens, E.H. and Sharpley, R. (2010). Icelandic tourism: Past directions-future challenges. Tourism Geographiers, vol. 12, no. 2, pp. 278-301.

Jones, C. and Munday, M. (2004). Evaluating the economic benefits from tourism spending through input-output frameworks: issues and cases. Local Economy, vol. 19, no. 2, pp. 117-133.

Jones, C. and Munday, M. (2007). Exploring the environmental consequences of tourism: A satellite account approach. Journal of Travel Research, vol. 46, no. 2, pp. 164-172.

Jones, C. and Munday, M. (2010). Tourism satellite accounts for regions? A review of development issues and an alternative.: Economic Systems Research, vol. 22, no. 4, pp. 341-358.

Jones, C., Munday, M. and Roberts, A. (2003). Regional tourism satellite accounts: A useful policy tool? Urban Studies, vol. 40, no. 13, pp. 2777-2794.

Jones, C., Munday, M. and Roberts, A. (2009). Top down or bottom up? Issues in the development of sub-national tourism satellite accounts. Current Issues in Tourism, vol. 12, no. 4, pp. 301-313.

Junkka, F. (2009). Regionala turism räkenskaper. En studie över möjligheterna att framställa regionala turismräkenskaper i Sverige, Arbetsrapport 2009-06-12, Östersund: Myndigheten för tillväxtpolitiska utvärderingar och analyser.

Kauppila, P., Saarinen, J. and Leinonen, R. (2009). Sustainable tourism planning and regional development in peripheries: A Nordic view. Scandinavian Journal of Hospitality and Tourism, vol. 9, no. 4, pp. 242-435.

Kolbe, W., \& Gustavsson, A. (2018). Turismhistoria i Norden, Acta Academiae Gustavi Adolphi CL, Uppsala: Kunglig Gustav Adolfs Akademien. 
Konttinen, J.P. (2006). Regional Tourism Satellite Account (RTSA) in Finland-Data, concepts, methods and key results, Conference paper, 46th Congress of the European Regional Science Association: 'Enlargement, Southern Europe and the Mediterranean ', August 30-September 3 2006, Volos (Greece).

Kronenberg, K., Lexhagen, M., \& Fuchs, M. (2014). Ekonomiska spridningseffekter inom turism-Forskningsöversikt och praktiska metoder. ETOUR Report 2014:4.

Kronenberg, K., Fuchs, M. and Lexhagen, M. (2018). A multi-period perspective on tourism's economic contribution-a regional input-output analysis for Sweden. Tourism Review, vol. 73, no. 1, pp. 94-110.

Madsen, B. and Zhang, J. (2010). Towards a new framework for accounting and modelling the regional and local impacts of tourism. Economic Systems Research, vol. 22, no. 4, pp. 313-340.

Mandle, J. R. (2018). Tourism and the future of the Iceland economy, Paper prepared for presentation at the University of Iceland, March 2, 2018.

Müller D.K., (2013). Rural Tourism in the Nordic Countries-A Short Assessment, in: Fredricsson C., \& Smas L. (eds). Small-scale tourism in rural areas: trends and research in Nordic countries, 41-46. Nordic Working group 1B: future rural areas. Nordregio Working paper 2013:3. Nordregio, Stockholm. http://www.nordregio.se/en/Publications/Publications-2013/Small-scale-Tourism-inRural-Areas/

Nielsen, A.M., Zhang, J., \& Javakshishvili-Larsen, N. (2019). Regional Economic Effects of Coastal and Marine Tourism in Denmark. Centre for Regional and Tourism Research. https://crt.dk/wpcontent/uploads/2019/02/Regional-economic-effect-of-coastal-and-maritime-tourism-inDenmark_01022019.pdf

Nordström, J. (1996). Tourism Satellite Account for Sweden 1992-1993. Tourism Economics, vol. 2, no. 1, pp. 13-42.

OECD (2010). OECD tourism trends and policies 2010, Paris: OECD.

OECD (2016): An OECD review of statistical initiatives measuring tourism at subnational level, OECD Tourism Papers 2016/01, Paris: OECD Publishing.

Paajanen, M. (1997). The Economic Impact Analysis of Tourism-Towards Methodological Development, 37th European Congress of the Regional Science Association, August 26-29, 1997, Rome, Italy, Parallel Session N3: History, Culture, Arts and Regional/Urban Economic Development.

Pham, T. D. and Dwyer, L. (2013). Tourism Satellite Accounts and their applications in CGE modelling, in: Clement A. Tisdell (Ed.), Handbook of tourism economics: Analysis, new applications and case studies, New Jersey: World Scientific, pp. 493-521.

Rinne, P \& Saastamoinen, O. (2005). Local Economic Role of Nature-based Tourism in Kuhmo Municipality, Eastern Finland, Scandinavian Journal of Hospitality and Tourism, 5 (2), 2005, 89-101.

Rossouw, R. and Saayman, M. (2011). Assimilation of tourism satellite accounts and applied general equilibrium models to inform tourism policy analysis. Tourism Economics, vol. 17, no. 4, pp. 753-783.

Rögnvaldsdóttir, L. B. (2014). Economic effects of tourism in Pingeyjarsýslur. Analysis at the subnational level in Iceland, Akureyri: Icelandic Tourism Research Centre.

Rögnvaldsdóttir, L. B. (2016). Tourism data collection. Analysis at the sub-national level in Iceland, Akureyri: Icelandic Tourism Research Centre.

Rütter, H. and Berwert, A. (1999). A regional approach for tourism satellite accounts and links to the National Account. Tourism Economics, vol. 5, no. 4, pp. 353-381.

Saarinen, J. (2003). The regional economics of tourism in Northern Finland: The socio-economic implications of recent tourism development and future possibilities for regional development. Scandinavian Journal of Hospitality and Tourism, vol. 3, no. 2, pp. 91-113. 
SCB (2018). The Tourism Satellite Account \& the Environment-Method Development, SCB Regioner och Miljö, MIR 2018:1.

Smeral, E. (2006). Tourism Satellite Accounts: A critical assessment. Journal of Travel Research, vol. 45, pp. 92-98.

Smeral, E. (2015). Tourism Satellite Accounts as a policy tool-some critical reflections, in: Harald Pechlander and Egon Smeral (eds.), Tourism and leisure. Current issues and perspectives of development, Wiesbaden: Springer Gabler, pp. 65-71.

SSB (2020). Tourism satellite accounts. https://www.ssb.no/en/nasjonalregnskap-ogkonjunkturer/statistikker/turismesat

Statistics Finland (2004). Final report of the Tourism Satellite Account project, available at: http://ktm.elinar.fi/ktm_jur/ktmjur.nsf/All/4A4961275CDE38B6C2256F6D0026AEE1/\$file/ englanninkielinen_ratu8mos_2004.pdf

Statistics Finland (2020). Transport and Tourism. https://www.stat.fi/til/lii_en.html

Statistics Finland (2020a). Statistics: Culture satellite accounts [e-publication]. ISSN=2323-9905. Helsinki: Statistics Finland [referred: 01.12.2020]. Access method: http://www.stat.fi/til/klts/index_en.html

Statistics Norway (2019). Tourism satellite accounts. About the statistics. Available from: https://www.ssb.no/en/turismesat

Statistics Iceland/ Hagstofa Íslands (2020) Fjöldi launpega í einkennandi atvinnugreinum ferðapjónustu 2008-janúar 2020, https://px.hagstofa.is/pxis/pxweb/is/Atvinnuvegir/ Atvinnuvegir ferdathjonusta ferdaidnadurhagvisar/SAM08051.px

Tillväxtverket (2019a). Turism, available at: https://tillvaxtverket.se/statistik/turism.html

Tillväxtverket (2019b). Fakta om svensk turism 2018, Stockholm: Tillväxtverket.

Tillväxtverket (2020). Turismens årsbokslut 2019, Stockholm: Tillväxtverket och SCB.

https://tillvaxtverket.se/statistik/vara-undersokningar/resultat-fran-turismundersokningar/ 2020-09-30-turismens-arsbokslut-2019.html

Tillväxtverket (2020b). Om turisträkenskaperna. Stockholm: Tillväxtverket, SCB, https://tillvaxtverket.se/statistik/turism/turismens-omsattning/om-turistrakenskaperna.html

Tohmo, T. (2018). The economic impact of tourism in Central Finland: A regional input-output study. Tourism Review, vol. 73, no. 4, pp. 521-547.

UNWTO (1999). Tourism Satellite Account (TSA)-The Conceptual Framework, Madrid: UNWTO. ISBN 978-92-844-0317-2.

UNWTO (2008). Sources and Methods: Labour Statistics-Employment in the Tourism Industries (Special Edition) Madrid: UNWTO.

United Nations Statistical Office (2010). Manual on Statistics of International Trade in Services 2010, Economy \& Society, New York: United Nations retrieved from: https://unstats.un.org/unsd/ tradeserv/TFSITS/msits2010/docs/MSITS\%202010\%20M86\%20(E)\%2Oweb.pdf

VisitFinland (2020). Key figures in regional tourism account by Indicator, Year and Region. http://visitfinland.stat.fi/PXWeb/pxweb/en/VisitFinland/

VisitFinland Alveellinen_matkailutilinpito/

010_amtp_tau_101.px/?rxid=ea589d71-c7bb-4fc4-9520-4842a4a00535

VisitFinland (2020). Regional Tourism Accounts, Retrieved from: http://visitfinland.stat.fi/ PXWeb/pxweb/en/VisitFinland/VisitFinland Alveellinen_matkailutilinpito/010_amtp_tau_101.px/ table/tableViewLayout1/?rxid=ea589d71-c7bb-4fc4-9520-4842a4a00535

VisitFinland (2O2Oa). Boosting the Finnish travel industry. Retrieved from: https://www.businessfinland.fi/en/for-finnish-customers/services/travel/travel

Visit Greenland (2017). Tourism Statistics Report 2016, available from: 
http://www.tourismstat.gl/resources/reports/en/r8/

GREENLAND\%2OTOURISM\%2OREPORT\%202016.pdf

VisitDenmark (2020). Videnscenter -Følg med i turismens udvikling, turisterne i Danmark og internationale tendenser inden for turismen. https://www.visitdenmark.dk/corporate/ videncenter

VisitDenmark (2020a). Turismens økonomiske betydning 25.25.2020. retrieved from https://www.visitdenmark.dk/corporate/videncenter/turismens-oekonomiske-betydning

VisitÅland (2019). Turismen på Åland. Retrieved from: https://www.visitaland.com/app/uploads/ sites/3/2020/02/Turismrapport-2019_print-.pdf

Zhang, J. (2019). Documentation on Regional Tourism Satellite Accounts in Denmark, Bornholm/ Copenhagen: Center for Regional and Tourism Research. https://crt.dk/wp-content/uploads/ 2019/01/rtsa-documentation_2018_revised-from-2005-1.pdf

Zhang, J. (2018). Documentation on Regional Tourism Satellite Accounts in Denmark, Bornholm/ Copenhagen: Center for Regional and Tourism Research.

Zhang, J. (2014). Tourist attraction development in Denmark and its impact on regions. Management Studies, vol. 2, no. 4, pp. 254-268.

Zhang, J. (2001). Tourism impact analysis on Danish regions, Paper presented at 41 Congress of the European Regional Science Association: 'European regional development issues in the new millennium and their impact on economic policy', 29 August-1 September 2001, Zagreb (Croatia).

Zhang, J., Madsen, B. and Jensen-Butler, C. (2007). Regional economic impacts of tourism: The case of Denmark. Regional Studies, vol. 41, no. 6, pp. 839-854.

ÅSUB/Statistics and Research Åland (2020). Ekonomisk översikt hösten 2020. Översikter och indikatorer 2020:5. Published 09.10.2020 retrieved at https://www.asub.ax/sites/www.asub.ax/ files/reports/o20205_ekonomisk_oversikt_hosten_2020_-_uppdaterad_O.pdf

ÅSUB/Statistics and Research Åland (2020a). Arbetslöshetssituationen December 2020a. Statistiskmeddelande. Arbetsmarknad. 2020:13, retrieved at https://www.asub.ax/sites/ www.asub.ax/files/statistics/arblos_12_2020_0.pdf

ÅSUB (2019): Turismens samhällsekonomiska betydelse för Åland 2018. Rapport 2019:2, Mariehamn: ÅSUB.

ÅSUB (2015) https://www.asub.ax/sv/statistik/socialrakenskapsmatris-aland-2015

ÅSUB (2010) https://www.asub.ax/sv/statistik/alands-socialrakenskapsmatris-2010

ÅSUB (2007) https://www.asub.ax/sv/statistik/alands-socialrakenskapsmatris-2007

ÅSUB (2016) National accounts statistics (in Swedish): https://www.asub.ax/sites/ www.asub.ax/files/statistics/bnp_meddelande_2016.pdf 


\section{Appendix}

\section{Appendix I}

\section{Many approaches to understand economic impacts of tourism}

There are various approaches to economic impacts analysis of tourism and applied techniques. Few of them will be mentioned here as a point of comparison.

According to UNWTO (2013) there are identified four key areas that should be considered when analysing economic effects:

1. Scope

2. Aggregation level

3. Time dimension

4. Geographic area.

The first attempt to develop Regional Tourism satellite accounts was in Australia (Kronenberg et.al., 2014). There is a range of descriptive tourism analysis tools, i.e. Tourism Benchmarking (i.e. Tyrolean Tourism Barometer) and shift-share analysis. While they have advantages i.e. that only small amount of data is needed for the benchmarking and it considers spatial variations the data requirements for benchmarking are small amount of input data but the weakness is that data input is average prices on accommodation rooms, so no sub-markets are considered in this methodology. The benefits of shift-share is that it enables to illustrate each hosting region's growth in relation to growth in i.e. Northern Europe. However very little data is required to obtain knowledge with high potential for managerial implications of tourism enterprises and thus it is mainly recommended as a support tool to strategic decision for the industry perspective rather than the political dimension (Kronenberg et.al., 2014).

Keynesian Multiplier models focusing on multiplication as the marginal propensity to consume and the marginal propensity to import, have been used to support taxation and spending policies in order to stimulate demand. The application to the tourism industry includes two additional components. This is the propensity of consumption by different visitor segments and shares of visitor spending in different industries. Input-output models' basic idea is to describe the flow of goods and services between all sectors of an economy over a period of time in the context of one table. The system quantifies the mutual interrelationship among the sectors. Input output models are rather incomplete and ignore key aspects of economy also in relation to tourism. Some of its elements are strongly simplified, i.e. labour markets. Thus illustrate poorly dynamics of tourism in that i.e. all jobs created are new jobs and there are no productivity changes, wages are fixed, no commutes from outside the region are hired and there are no seasonal variations or differences between skilled and unskilled jobs or people holding multiple jobs( highly rigid perspective in relation to tourism) (Kronenberg et.al., 2014).

One widely used $1 O$ model in Economic impact analyses is the IMPLAN model which is based on the theoretical conditions of input-output in its fundamental assumptions. i.e. it has been applied to analyse the impact of tourists 'expenditure for a regional economy and understand changes in industrial output, employment, income and taxes. An example of how this has been applied is in Vermont, US a study analysed the impact of Vermont tourists' expenditure on the state economy, annually and seasonally. The economic impact of tourism comprised changes in industrial output, employment, income and taxes. Both direct and secondary effects could be measured. The IMPLAN required three different types of data sources combined for conducting a regional tourism EIA. These were visitor surveys, business surveys for selected tourism related businesses; lodging, eat \&drink and ski areas, supplied by national average data and Data about the States economy for a certain year (1996) (further reading UOV, 1999).

A more recent study from Central Finland (Tohmo, 2018) applied input output analysis to 
understand the economic impact of tourism in the region. The author's regional input-output analysis reveals that tourism has a substantial impact on production in Central Finland (including the direct and indirect effects of consumption by tourists in different sectors).

Moreover, the effects of tourism expenditures on employment and residents' incomes in tourismrelated sectors in Central Finland are quite significant. However, there were many limitations of this study that stem from the assumptions of the input-output model. Other limitations relate to the analysis of the impacts of tourism on household taxes, savings, consumption, and net income. They used average figures, which risks overstating the effect of tourist expenditures on taxes because tourism jobs are often low paying. For the practical implications however, the study yielded results that can be used to frame regional policy. Results like that may be useful for policymakers in planning for tourist attractions. Furthermore, local authorities may use the results to guide decisions regarding infrastructure investments or improvements to the operating environment of tourism industries (Tohmo, 2018).

Several countries and regions, i.e. Australia, Brazil, China, Turkey, Florida and more have applied the social account matrix (SAM) to analyse the impact of international tourism. The method is based on extending the IO-table by considering more detailed transactions in a certain economy. It thus further disaggregates relationships among suppliers, purchasers and factors of production. The complexity however is a limitation in that each matrix is individually developed and cannot be replicated into a common universal structure transferable from one region to another (Kronenberg et.al., 2014).

Commonly used techniques to approach economic impact analysis in a tourism context, such as Input-Output analyses and multiplier effects, are recognized to have some major weaknesses (e.g. no resource limitations, fixed prices, wages and profits, or omitted tax variables). CGE models (Computable General Equilibrium models) attempt to overcome many of these previously mentioned approaches, e.g. the estimation of the impact of a variety of changes in policies across sectors or the implication of limited resources in the economy.

The CGE can incorporate existing Tourism satellite accounts defining Tourism as an own sector. They are used increasingly in tourism analysis, though they have distinctly different functions. The first of these involves developing measures of profitability and productivity of the Australian tourism industry - the national TSA was used to provide the database for this exercise. The second involves measuring the yield of different types of tourists to the tourism industry and the economy as a whole. TSAs provide an appropriate technique to estimate economic yield at the industry level, while the CGE approach is used to estimate the yield to the economy as a whole (Dwyer, Forsyth \& Spurr, 2007).

More recently the Regional Tourism satellite Accounts (TSA) are being developed into a webbased information system. So far only in China (Chenguang et.al., 2019). 


\section{Appendix II}

\section{Available tourism related data sets from each Nordic Country}

\section{Denmark}

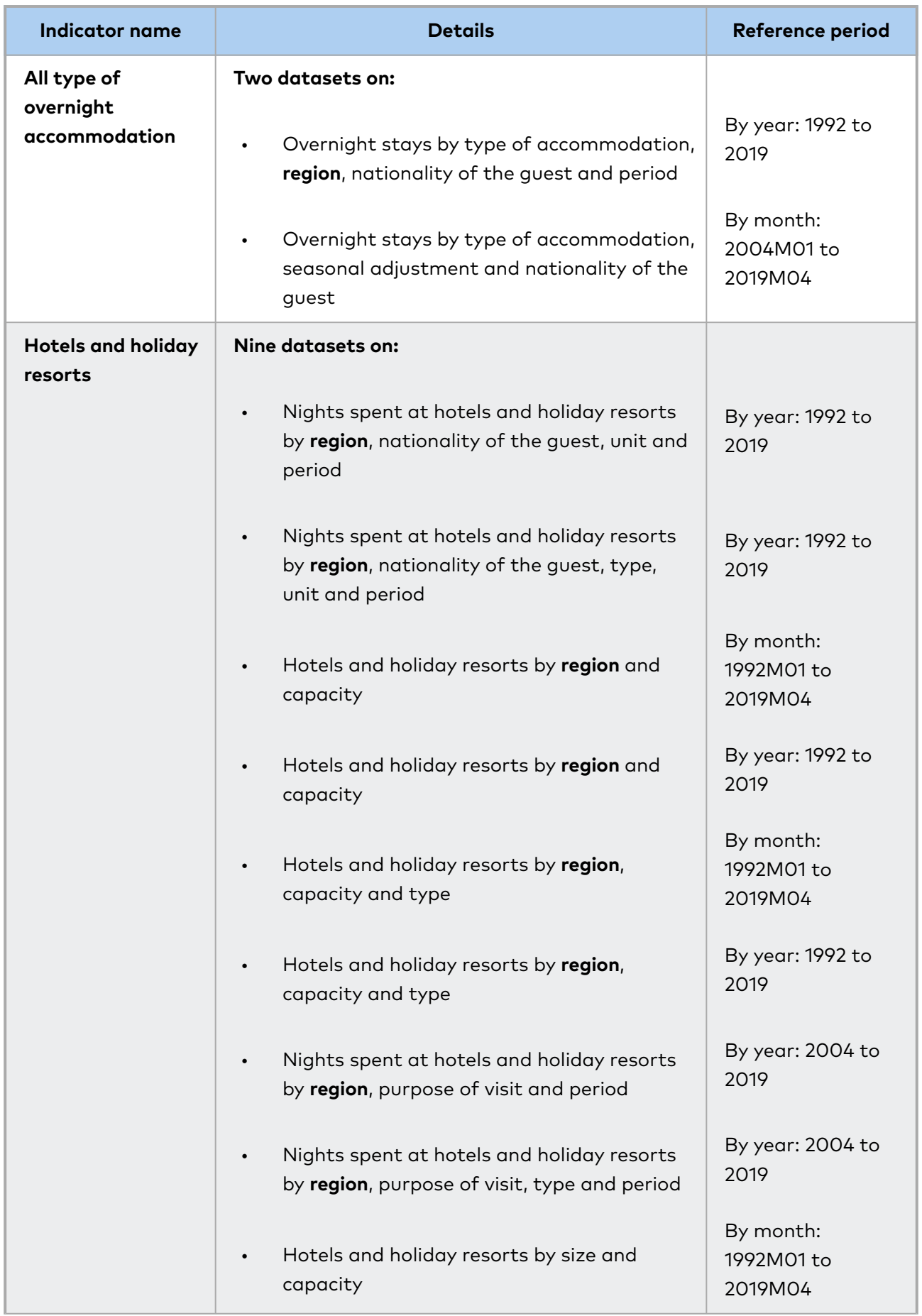




\begin{tabular}{|l|l|l|}
\hline Youth hostels & $\begin{array}{l}\text { Nights spent in youth hostels by region, } \\
\text { nationality of the guest and period }\end{array}$ & $\begin{array}{l}\text { By year: 1998 to } \\
2019\end{array}$ \\
\hline Source & Statistics Denmark, Statbank & \\
\hline
\end{tabular}

Table 1. Hotels, holiday centres and youth hostels

\begin{tabular}{|c|c|c|}
\hline Indicator name & Details & Reference period \\
\hline $\begin{array}{l}\text { Letting of holiday } \\
\text { houses, monthly }\end{array}$ & $\begin{array}{l}\text { By region ( } 121 \text { categories) } \\
\text { By nationality of the guest ( } 7 \text { categories) } \\
\text { By unit: } \\
\text { - Nights spent } \\
\text { - Weeks of rental } \\
\text { Contracts } \\
\text { - Available house-weeks } \\
\text { By period (14 categories) }\end{array}$ & $\begin{array}{l}\text { By year: } 2017 \text { to } \\
2019\end{array}$ \\
\hline $\begin{array}{l}\text { Letting of holiday } \\
\text { houses, monthly }\end{array}$ & $\begin{array}{l}\text { By nationality of the guest ( } 7 \text { categories) } \\
\text { By unit: } \\
\text { - Nights spent } \\
\text { - Weeks of rental } \\
\text { - Contracts } \\
\text { - Available house-weeks } \\
\text { By period (14 categories) }\end{array}$ & $\begin{array}{l}\text { By year: } 2004 \text { to } \\
2019\end{array}$ \\
\hline $\begin{array}{l}\text { Future house } \\
\text { weeks booked at } \\
\text { holiday houses }\end{array}$ & $\begin{array}{l}\text { By nationality of the guest ( } 7 \text { categories) } \\
\text { By future year ( } 15 \text { categories) } \\
\text { By future month ( } 12 \text { categories) }\end{array}$ & $\begin{array}{l}\text { By month: } \\
2005 \mathrm{M01} \text { to } \\
2019 \mathrm{MO} 4\end{array}$ \\
\hline $\begin{array}{l}\text { Weeks of rental in } \\
\text { holiday houses }\end{array}$ & $\begin{array}{l}\text { By unit (8 categories) } \\
\text { - Total weeks of rental } \\
\text { - Weeks of rental Denmark } \\
\text { - Weeks of rental Sweden }\end{array}$ & $\begin{array}{l}\text { By year: } 2008 \text { to } \\
2018\end{array}$ \\
\hline
\end{tabular}




\begin{tabular}{|c|c|c|}
\hline & $\begin{array}{l}\text { - Weeks of rental Norway } \\
\text { - Weeks of rental Germany } \\
\text { - Weeks of rental Netherlands } \\
\text { - Weeks of rental unknown countries } \\
\text { - Available holiday houses } \\
\text { By period (53 categories) }\end{array}$ & \\
\hline $\begin{array}{l}\text { Holiday houses for } \\
\text { rent }\end{array}$ & By capacity (1 category) & $\begin{array}{l}\text { By year: } 2012 \text { to } \\
2018\end{array}$ \\
\hline $\begin{array}{l}\text { Letting of holiday } \\
\text { houses }\end{array}$ & $\begin{array}{l}\text { By region ( } 17 \text { categories) } \\
\text { By nationality of the guest ( } 7 \text { categories) } \\
\text { By unit ( } 3 \text { categories) }\end{array}$ & $\begin{array}{l}\text { By year: } 1992 \text { to } \\
2018\end{array}$ \\
\hline Source & Statistics Denmark, Statbank & \\
\hline
\end{tabular}

Table 2. Holiday dwellings

\begin{tabular}{|c|c|c|}
\hline Indicator name & Details & Reference period \\
\hline $\begin{array}{l}\text { Nights spent on } \\
\text { camping sites }\end{array}$ & $\begin{array}{l}\text { By region ( } 6 \text { categories) } \\
\text { By nationality of the guest ( } 54 \text { categories) } \\
\text { By unit: } \\
\text { - Nights stay } \\
\text { Bereof in permanent camping slot } \\
\text { By period ( } 14 \text { categories) }\end{array}$ & $\begin{array}{l}\text { By year: } 1992 \text { to } \\
2019\end{array}$ \\
\hline Camping sites & $\begin{array}{l}\text { By region (6 categories) } \\
\text { By capacity: } \\
\text { - Number of camping sites } \\
\text { - Number of camping units } \\
\text { - Use of capacity (per cent) }\end{array}$ & $\begin{array}{l}\text { By month: } \\
1992 \mathrm{MO} 3 \text { to } \\
2019 \mathrm{MO} 4\end{array}$ \\
\hline Camping sites & $\begin{array}{l}\text { By region (6 categories) } \\
\text { By capacity: } \\
\text { - Number of camping sites - max }\end{array}$ & $\begin{array}{l}\text { By year: } 1992 \text { to } \\
2018\end{array}$ \\
\hline
\end{tabular}




\begin{tabular}{|l|l|l|}
\hline & Number of camping sites - min \\
$\cdot$ & Number of camping units - max \\
$\cdot$ & Number of camping units - min \\
Source & Use of capacity (per cent) \\
\hline
\end{tabular}

Table 3. Camping sites

\begin{tabular}{|c|c|c|}
\hline Indicator name & Details & Reference period \\
\hline $\begin{array}{l}\text { Nights spent at } \\
\text { marinas with } \\
\text { overnight } \\
\text { accommodations }\end{array}$ & $\begin{array}{l}\text { By region ( } 17 \text { categories) } \\
\text { By nationality of the guest ( } 27 \text { categories) } \\
\text { By period ( } 7 \text { categories) } \\
\text { By type of overnight accommodation: } \\
\text { Guest nights } \\
\text { - Boat nights }\end{array}$ & $\begin{array}{l}\text { By year: } 1992 \text { to } \\
2018\end{array}$ \\
\hline $\begin{array}{l}\text { Nights spent at } \\
\text { marinas with } \\
\text { overnight } \\
\text { accommodations }\end{array}$ & $\begin{array}{l}\text { By waters ( } 13 \text { categories) } \\
\text { By nationality of the guest ( } 27 \text { categories) } \\
\text { By period ( } 7 \text { categories) } \\
\text { By type of overnight accommodation: } \\
\text { - Guest nights } \\
\text { - Boat nights }\end{array}$ & $\begin{array}{l}\text { By year: } 1992 \text { to } \\
2018\end{array}$ \\
\hline Marinas & $\begin{array}{l}\text { By size (10 categories) } \\
\text { By capacity: } \\
\text { Marinas } \\
\text { Permanent mooring } \\
\text { Boat nights } \\
\text { - Guest nights }\end{array}$ & $\begin{array}{l}\text { By year: } 1992 \text { to } \\
2018\end{array}$ \\
\hline Marinas & $\begin{array}{l}\text { By region ( } 12 \text { categories) } \\
\text { By capacity: }\end{array}$ & $\begin{array}{l}\text { By year: } 1992 \text { to } \\
2018\end{array}$ \\
\hline
\end{tabular}




\begin{tabular}{|c|c|c|}
\hline & $\begin{array}{l}\text { - } \text { Marinas } \\
\text { - } \text { Permanent mooring } \\
\text { - Boat nights - paid } \\
\text { - Boat nights - free of charge } \\
\text { - Guest nights }\end{array}$ & \\
\hline $\begin{array}{l}\text { Nights spent at } \\
\text { marinas with } \\
\text { overnight } \\
\text { accommodations }\end{array}$ & $\begin{array}{l}\text { By region ( } 17 \text { categories) } \\
\text { By nationality of the guest ( } 27 \text { categories) } \\
\text { By period ( } 7 \text { categories) }\end{array}$ & $\begin{array}{l}\text { By year: } 1992 \text { to } \\
2018\end{array}$ \\
\hline $\begin{array}{l}\text { Nights spent at } \\
\text { marinas with } \\
\text { overnight } \\
\text { accommodations }\end{array}$ & $\begin{array}{l}\text { By waters ( } 13 \text { categories) } \\
\text { By nationality of the guest ( } 27 \text { categories) } \\
\text { By period ( } 7 \text { categories) }\end{array}$ & $\begin{array}{l}\text { By year: } 1992 \text { to } \\
2018\end{array}$ \\
\hline Source & Statistics Denmark, Statbank & \\
\hline
\end{tabular}

Table 4. Marina

\begin{tabular}{|c|c|c|}
\hline Indicator name & Details & Reference period \\
\hline Holidays abroad & $\begin{array}{l}\text { By destination (50 categories) } \\
\text { By duration: } \\
\text { - Less than four nights stays } \\
\text { - Four overnights stays or more }\end{array}$ & $\begin{array}{l}\text { By year: } 2001 \text { to } \\
2018\end{array}$ \\
\hline Holidays & $\begin{array}{l}\text { By destination: } \\
\text { - Denmark } \\
\text { - World outside Denmark } \\
\text { By duration: } \\
\text { - Less than four nights stays } \\
\text { - Four overnights stays or more } \\
\text { By purpose (13 categories) }\end{array}$ & $\begin{array}{l}\text { By year: } 2007 \text { to } \\
2018\end{array}$ \\
\hline
\end{tabular}




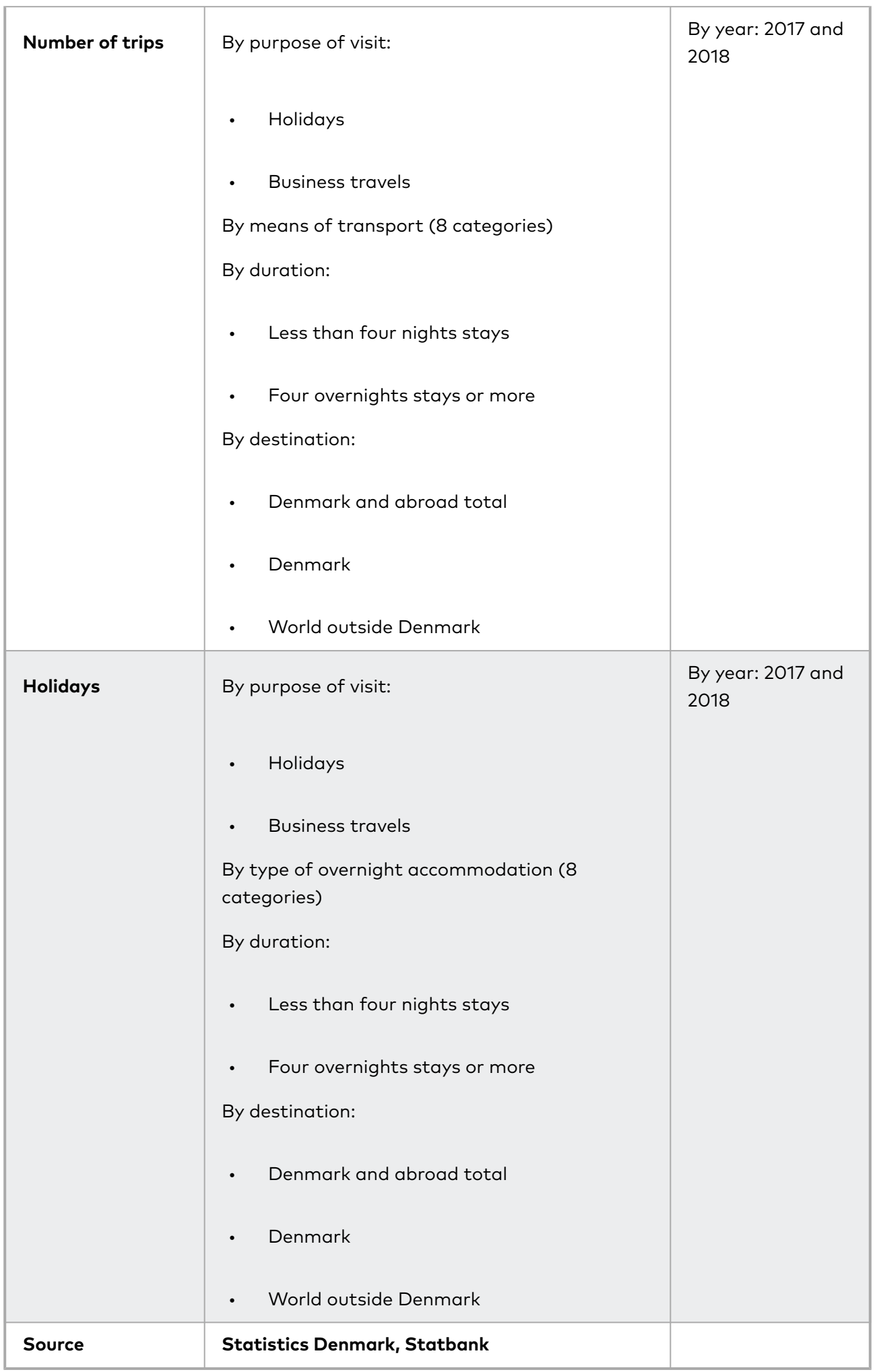

Table 5. Holiday and business trips 


\section{Finland}

\begin{tabular}{|c|c|c|}
\hline Indicator name & Details & Reference perioc \\
\hline $\begin{array}{l}\text { Monthly nights } \\
\text { spent and arrivals } \\
\text { by country of } \\
\text { residence }\end{array}$ & $\begin{array}{l}\text { By nights spent and arrivals ( } 10 \text { categories) } \\
\text { By Finnish region ( } 122 \text { categories) } \\
\text { By country of residence ( } 94 \text { categories) }\end{array}$ & $\begin{array}{l}\text { By month: } \\
1995 \mathrm{MO} 1 \text { to } \\
2019 \mathrm{MO} 4\end{array}$ \\
\hline $\begin{array}{l}\text { Yearly nights spent } \\
\text { and arrivals by } \\
\text { country of } \\
\text { residence }\end{array}$ & $\begin{array}{l}\text { By nights spent and arrivals ( } 9 \text { categories) } \\
\text { By Finnish region ( } 122 \text { categories) } \\
\text { By country of residence ( } 94 \text { categories) }\end{array}$ & $\begin{array}{l}\text { By year: } 1995 \text { to } \\
2019 \text { (Jan-Apr) }\end{array}$ \\
\hline $\begin{array}{l}\text { Nights spent and } \\
\text { arrivals by tourism } \\
\text { season and } \\
\text { country of } \\
\text { residence }\end{array}$ & $\begin{array}{l}\text { By nights spent and arrivals ( } 9 \text { categories) } \\
\text { By tourism season ( } 6 \text { categories) } \\
\text { By Finnish region ( } 122 \text { categories) } \\
\text { By country of residence ( } 94 \text { categories) }\end{array}$ & $\begin{array}{l}\text { By year: } 1996 \text { to } \\
2019\end{array}$ \\
\hline $\begin{array}{l}\text { Monthly nights } \\
\text { spent by type of } \\
\text { establishment and } \\
\text { purpose of stay }\end{array}$ & $\begin{array}{l}\text { By nights spent, arrivals and purpose of stay ( } 11 \\
\text { categories) } \\
\text { By Finnish region ( } 28 \text { categories) } \\
\text { By type of establishment: } \\
\text { - All establishments } \\
\text { Hotels } \\
\text { Other establishments } \\
\text { By country: } \\
\text { Total } \\
\text { Domestic } \\
\text { Foreign }\end{array}$ & $\begin{array}{l}\text { By month: } \\
1995 \mathrm{MO} 1 \text { to } \\
2019 \mathrm{MO} 4\end{array}$ \\
\hline $\begin{array}{l}\text { Yearly nights spent } \\
\text { by type of } \\
\text { establishment and } \\
\text { purpose of stay }\end{array}$ & $\begin{array}{l}\text { By nights spent, arrivals and purpose of stay ( } 11 \\
\text { categories) } \\
\text { By Finnish region ( } 28 \text { categories) } \\
\text { By type of establishment: } \\
\text { - All establishments }\end{array}$ & $\begin{array}{l}\text { By year: } 1995 \text { to } \\
2019 \text { (Jan-Apr) }\end{array}$ \\
\hline
\end{tabular}




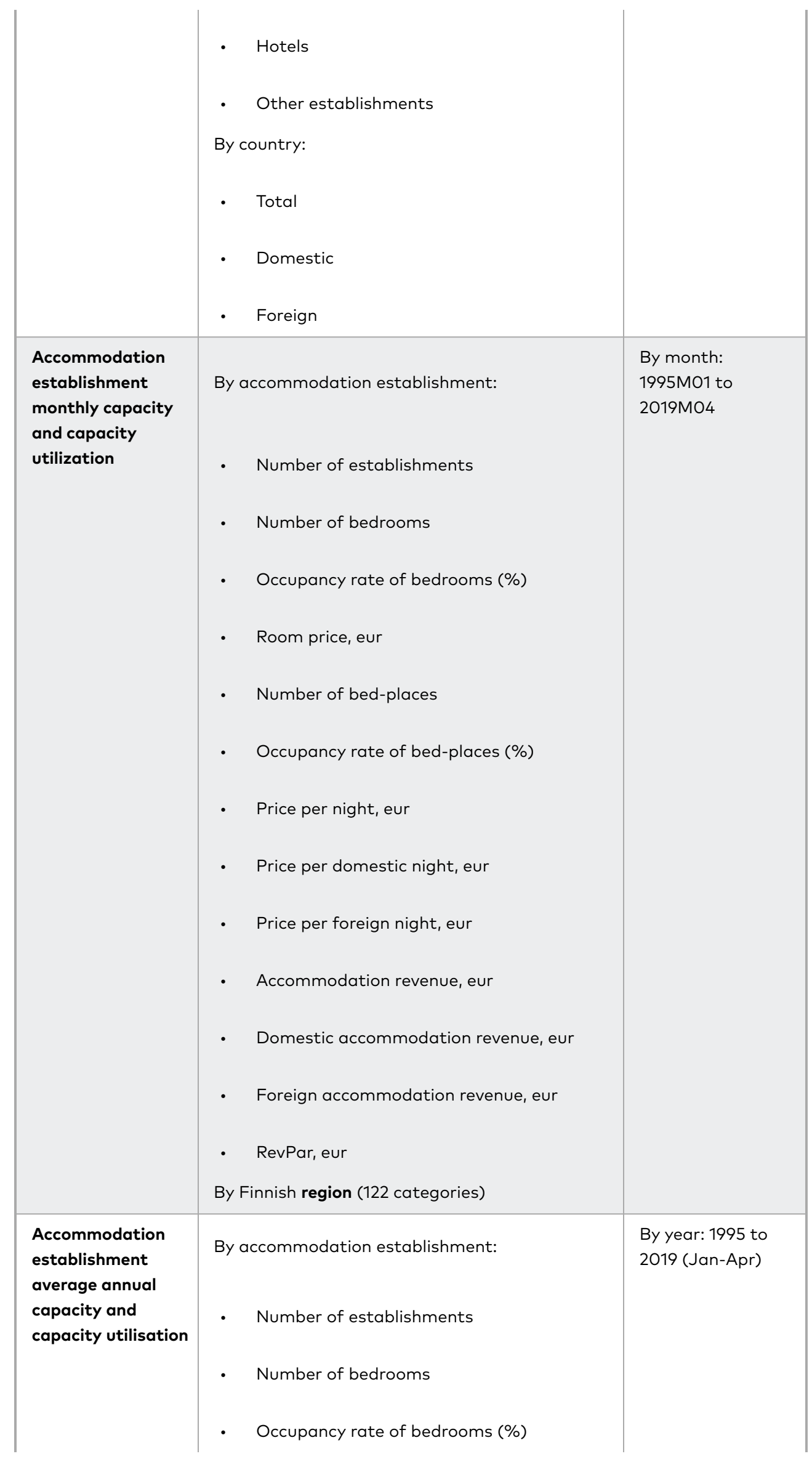


Room price, eur

- Number of bed-places

- Occupancy rate of bed-places (\%)

- Price per night, eur

- Price per domestic night, eur

- Price per foreign night, eur

- Accommodation revenue, eur

- Domestic accommodation revenue, eur

- Foreign accommodation revenue, eur

- RevPar, eur

By Finnish region (122 categories)

Visit Finland, Statistics Service Rudolf

Table 6. Accommodation Statistics

\begin{tabular}{|c|c|c|}
\hline Indicator name & Details & Reference period \\
\hline $\begin{array}{l}\text { Key figures in } \\
\text { regional tourism } \\
\text { account }\end{array}$ & $\begin{array}{l}\text { By indicator: } \\
\text { - } \quad \text { Total tourism demand (EUR million) } \\
\text { - Inbound tourism demand (EUR million) } \\
\text { - Domestic tourism demand (EUR million) } \\
\text { - Domestic leisure tourism demand (EUR } \\
\text { million) } \\
\text { Other domestic tourism demand } \\
\text { (compensated business trips, own free-time } \\
\text { residences), EUR million } \\
\text { Inbound tourism demand total, share of } \\
\text { total tourism demand (\%) } \\
\text { - Domestic leisure tourism demand total, } \\
\text { share of total tourism demand (\%) } \\
\text { Other domestic tourism demand }\end{array}$ & $\begin{array}{l}\text { By year: } 2013 \text { to } \\
2018\end{array}$ \\
\hline
\end{tabular}


(compensated business trips, own free-time residences), share of total tourism demand (\%)

- Tourism value added as a share of GDP at basic prices (\%, incl. employers' expenses)

- Tourism value added as a share of GDP at basic prices (\%, excl. employers' expenses)

- Value added generated by tourism demand (EUR million, incl. employers' expenses)

- Value added generated by tourism demand (EUR million, excl. employers' expenses)

- GDP at basic prices (EUR million)

- Employment in tourism industries, persons

- Number of hours worked in tourism industries (millions of hours)

- Tourism-related employment in tourism industries (number of persons employed)

- Tourism related employment in tourism industries (number of hours worked, million hours)

- People employed in tourism industries as a share of all employed people (\%)

By Finnish region (20 categories)

\begin{tabular}{|c|c|c|}
\hline $\begin{array}{l}\text { Inbound tourism } \\
\text { expenditure }\end{array}$ & $\begin{array}{l}\text { By product ( } 25 \text { categories) } \\
\text { By Finnish region ( } 20 \text { categories) } \\
\text { By category of visitors: } \\
\text { - Total visitors } \\
\text { - Same-day visitors } \\
\text { - Tourists }\end{array}$ & $\begin{array}{l}\text { By year: } 2013 \text { to } \\
2018\end{array}$ \\
\hline $\begin{array}{l}\text { Domestic tourism } \\
\text { expenditure }\end{array}$ & $\begin{array}{l}\text { By destination country: } \\
\text { - All trips of residents } \\
\text { - Domestic trips of residents }\end{array}$ & $\begin{array}{l}\text { By year: } 2013 \text { to } \\
2018\end{array}$ \\
\hline
\end{tabular}




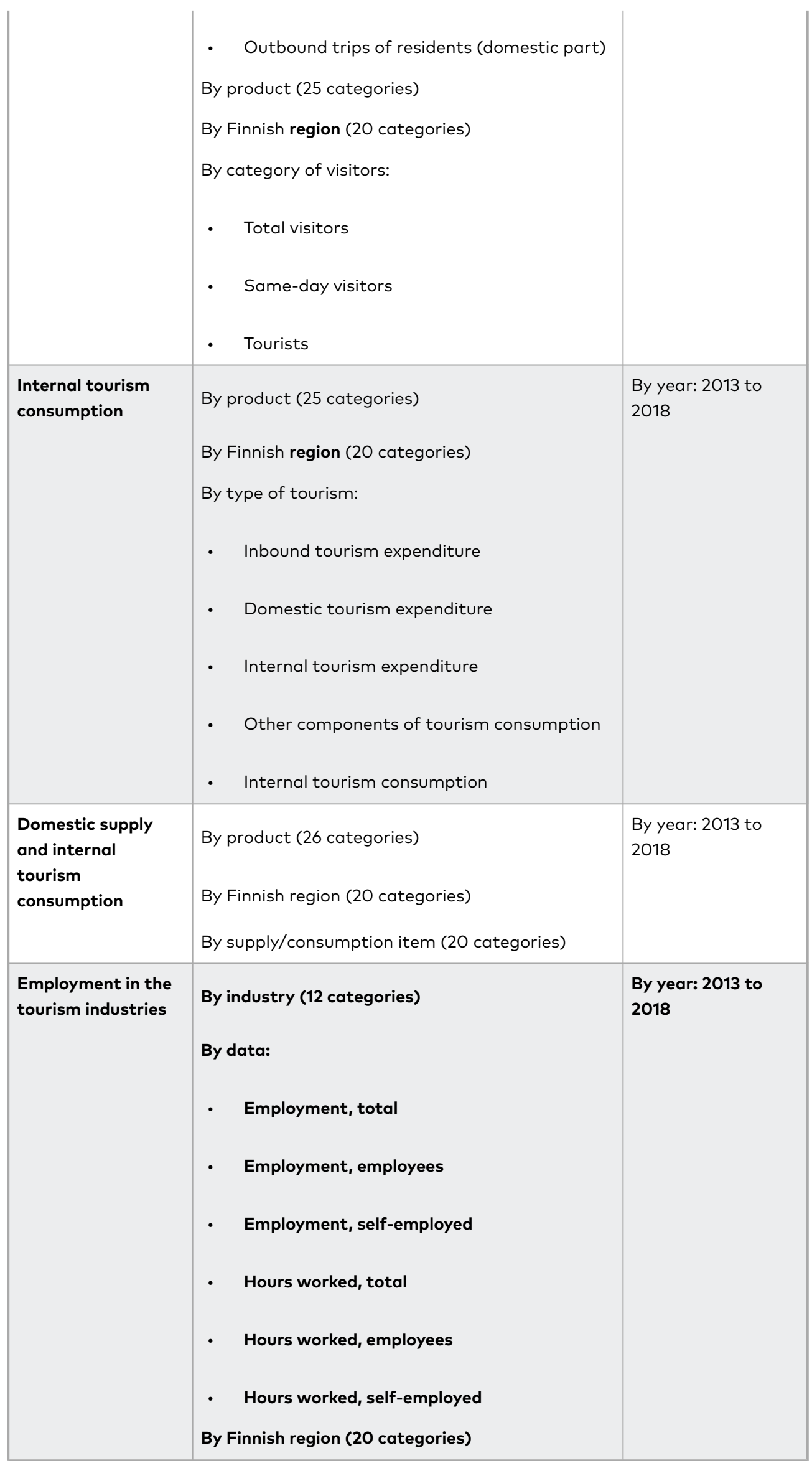


Table 7. Regional tourism accounts

\begin{tabular}{|c|c|c|}
\hline Indicator name & Details & Reference period \\
\hline $\begin{array}{l}\text { Occupancy and } \\
\text { prices of rental } \\
\text { cottages in } \\
\text { mainland Finland }\end{array}$ & $\begin{array}{l}\text { By information: } \\
\text { - Number of rental cottages } \\
\text { - Number of beds } \\
\text { - } \text { Cottage days sold } \\
\text { - } \quad \text { Domestic nights spent } \\
\text { - } \quad \text { Foreign nights spent } \\
\text { - Nights spent in total } \\
\text { - Occupancy rate of cottages } \\
\text { - Occupancy rate of beds } \\
\text { - } \text { Pottage price per day }\end{array}$ & $\begin{array}{l}\text { By month: } \\
2018 \mathrm{MO} 1 \text { to } \\
2019 \mathrm{MO} 4\end{array}$ \\
\hline $\begin{array}{l}\text { Capacity of rental } \\
\text { cottages by region } \\
\text { in mainland } \\
\text { Finland }\end{array}$ & $\begin{array}{l}\text { By information: } \\
\text { - Number of rental cottages } \\
\text { - Number of beds } \\
\text { By Finnish region ( } 20 \text { categories) }\end{array}$ & $\begin{array}{l}\text { By month: } \\
2018 M 01 \text { to } \\
2019 M 04\end{array}$ \\
\hline Source & Visit Finland, Statistics Service Rudolf & \\
\hline
\end{tabular}

Table 8. Statistics on rental cottages

\begin{tabular}{|l|l|l|}
\hline \multicolumn{1}{|c|}{ Indicator name } & \multicolumn{1}{|c|}{ Details } & \multicolumn{1}{|c|}{ Reference period } \\
\hline $\begin{array}{l}\text { Key figures in } \\
\text { tourism account }\end{array}$ & By indicator/key figure (18 categories) & $\begin{array}{l}\text { By year: } 1995 \text { to } \\
2017\end{array}$ \\
\hline $\begin{array}{l}\text { Inbound tourism } \\
\text { expenditure }\end{array}$ & By product (25 categories) & $\begin{array}{l}\text { By year: } 1995 \text { to } \\
2018\end{array}$ \\
\hline & By category of visitor: & \\
\hline
\end{tabular}




\begin{tabular}{|c|c|c|}
\hline & $\begin{array}{l}\text { - Total visitors } \\
\text { - Same-day visitors } \\
\text { - Tourists }\end{array}$ & \\
\hline $\begin{array}{l}\text { Domestic tourism } \\
\text { expenditure }\end{array}$ & $\begin{array}{l}\text { By products ( } 25 \text { categories) } \\
\text { By destination country: } \\
\text { - All trips of residents } \\
\text { - Domestic trips of residents } \\
\text { - Outbound trips of residents (domestic part) } \\
\text { By category of visitor: } \\
\text { - Total visitors } \\
\text { - Same-day visitors } \\
\text { Tourists }\end{array}$ & $\begin{array}{l}\text { By year: } 1995 \text { to } \\
2018\end{array}$ \\
\hline $\begin{array}{l}\text { Internal tourism } \\
\text { consumption }\end{array}$ & $\begin{array}{l}\text { By product ( } 25 \text { categories) } \\
\text { By type of tourism: } \\
\text { - Inbound tourism expenditure } \\
\text { - Domestic tourism expenditure } \\
\text { - Internal tourism expenditure } \\
\text { - Other components of tourism consumption } \\
\text { - Internal tourism consumption }\end{array}$ & $\begin{array}{l}\text { By year: } 1995 \text { to } \\
2018\end{array}$ \\
\hline $\begin{array}{l}\text { Domestic supply } \\
\text { and internal } \\
\text { tourism } \\
\text { consumption }\end{array}$ & $\begin{array}{l}\text { By product ( } 25 \text { categories) } \\
\text { By supply/consumption item ( } 34 \text { categories) }\end{array}$ & $\begin{array}{l}\text { By year: } 1995 \text { to } \\
2018\end{array}$ \\
\hline Source & Visit Finland, Statistics Service Rudolf & \\
\hline
\end{tabular}

Table 9. Tourism accounts (national level) 


\begin{tabular}{|c|c|c|}
\hline Indicator name & Details & Reference period \\
\hline $\begin{array}{l}\text { Travel-related } \\
\text { credits and debits }\end{array}$ & $\begin{array}{l}\text { By information: } \\
\text { - Credit, million euro } \\
\text { - Debit, million euro } \\
\text { - Credit annual change (\%) } \\
\text { - Debit annual change }(\%)\end{array}$ & $\begin{array}{l}\text { By quarter: } 2001 \mathrm{Q} 1 \\
\text { to } 2019 \mathrm{Q} 1\end{array}$ \\
\hline $\begin{array}{l}\text { Travel-related } \\
\text { credits by country }\end{array}$ & $\begin{array}{l}\text { By country ( } 25 \text { categories) } \\
\text { By information: } \\
\text { - Credit, million euro } \\
\text { - Credit annual change (\%) }\end{array}$ & $\begin{array}{l}\text { By year: } 2001 \text { to } \\
2017\end{array}$ \\
\hline Source & Visit Finland, Statistics Service Rudolf & \\
\hline
\end{tabular}

Table 10. Travel-related credits and debits

\section{Iceland}

\begin{tabular}{|c|c|c|}
\hline Indicator type & Details & Reference period \\
\hline \multirow[t]{6}{*}{$\begin{array}{l}\text { Hotels and guest } \\
\text { houses }\end{array}$} & Five datasets on & \\
\hline & $\begin{array}{l}\text { - Overnight stays in hotels (by citizenship, } \\
\text { region and month) }\end{array}$ & 1997 to 2019 \\
\hline & $\begin{array}{l}\text { - Overnight stays and arrivals in hotels (by } \\
\text { citizenship, month and unit) }\end{array}$ & 1998 to 2019 \\
\hline & $\begin{array}{l}\text { - Occupancy rate of rooms and beds in hotels } \\
\text { (by month, region and occupancy) }\end{array}$ & 2000 to 2019 \\
\hline & $\begin{array}{l}\text { - Overnight stays in hotels and guesthouses } \\
\text { (by citizenship, region and month) }\end{array}$ & 1998 to 2019 \\
\hline & $\begin{array}{l}\text { - Number of hotels, bedrooms and bedplaces } \\
\text { in regions (by value and region) }\end{array}$ & $\begin{array}{l}2015 \mathrm{MO} 1 \text { to } \\
2019 \mathrm{MO} 4\end{array}$ \\
\hline \multirow[t]{2}{*}{$\begin{array}{l}\text { Other } \\
\text { accommodations }\end{array}$} & Nine datasets on & \\
\hline & - Overnight stays in apartment hotels (by & 2005 to 2019 \\
\hline
\end{tabular}




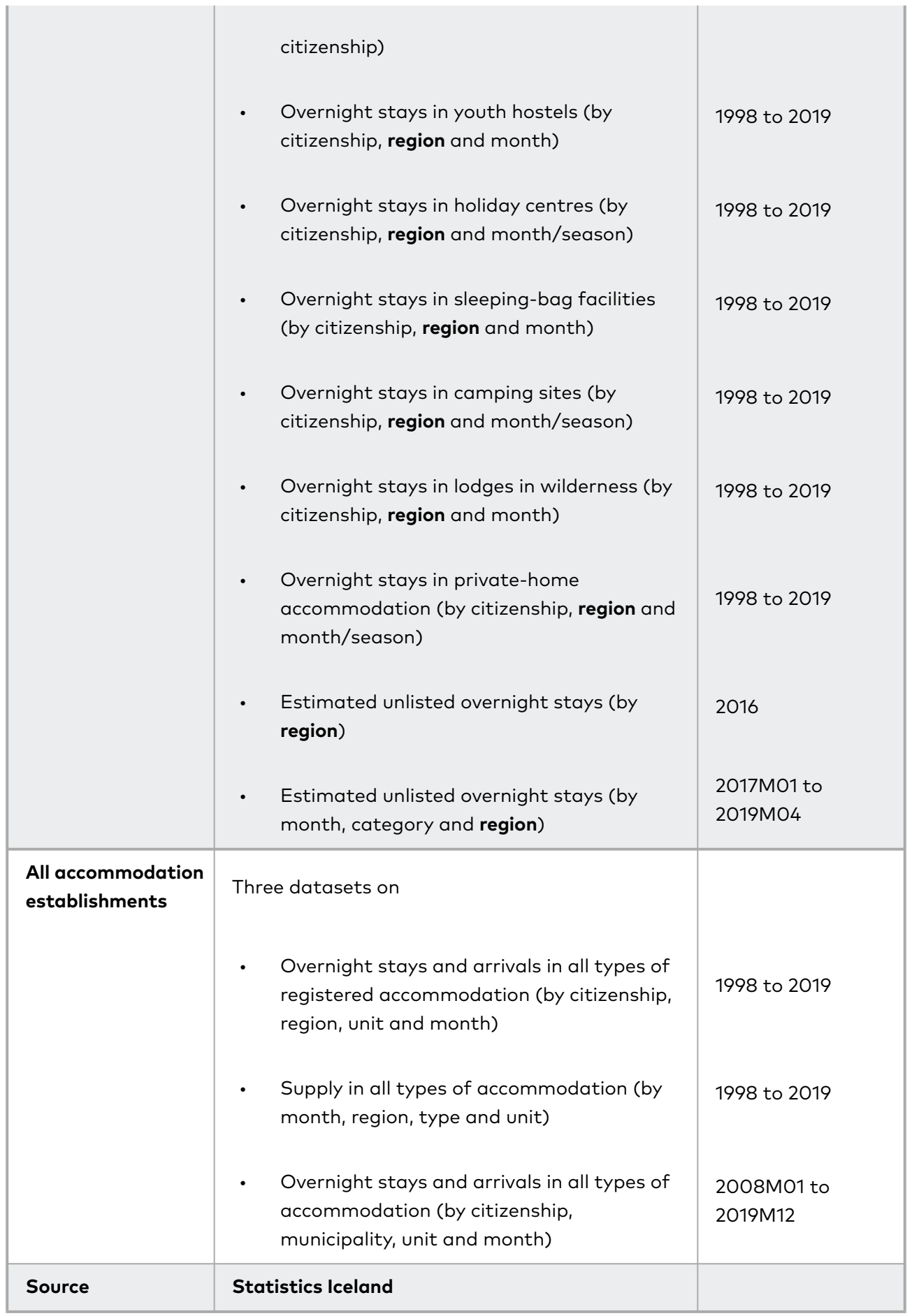

Table 11. Accomodation

\begin{tabular}{|l|l|l|}
\hline \multicolumn{1}{|c|}{ Indicator name } & \multicolumn{1}{|c|}{ Details } & \multicolumn{1}{|c|}{ Reference period } \\
\hline $\begin{array}{l}\text { Passengers and } \\
\text { tourists through } \\
\text { Keflavik airport }\end{array}$ & By citizenship: & By month: \\
& & $2015 \mathrm{MO}$ to \\
& 2019M05 \\
& Passenger total & \\
\hline
\end{tabular}




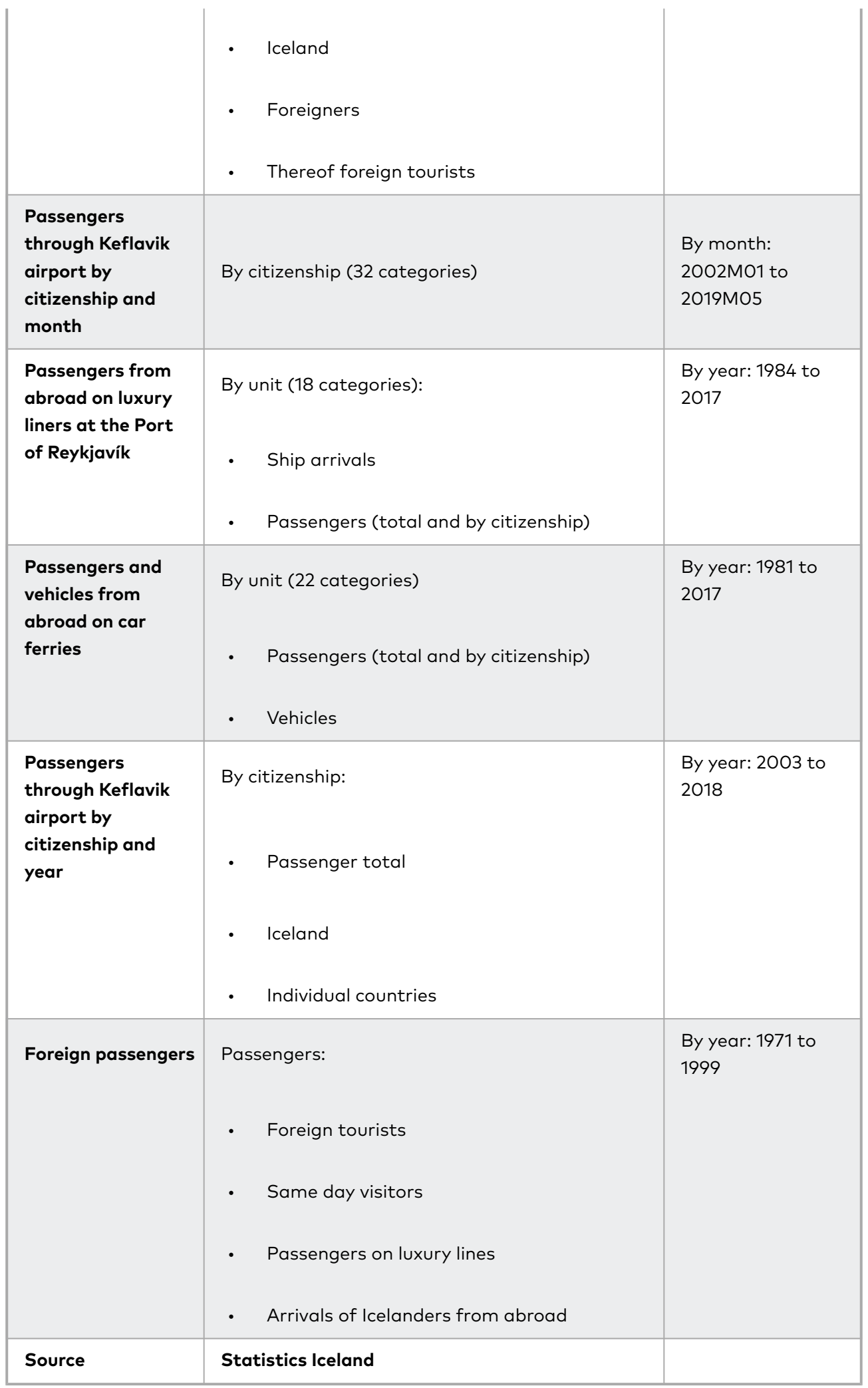

Table 12. Statistics on Passengers

\begin{tabular}{|l|l|l|}
\hline \multicolumn{1}{|c|}{ Indicator name } & \multicolumn{1}{|c|}{ Details } & \multicolumn{1}{|c|}{ Reference period } \\
\hline $\begin{array}{l}\text { Inbound tourism } \\
\text { expenditure in }\end{array}$ & By activity (14 categories): & $\begin{array}{l}\text { By year: } 2009 \text { to } \\
2017\end{array}$ \\
\hline
\end{tabular}




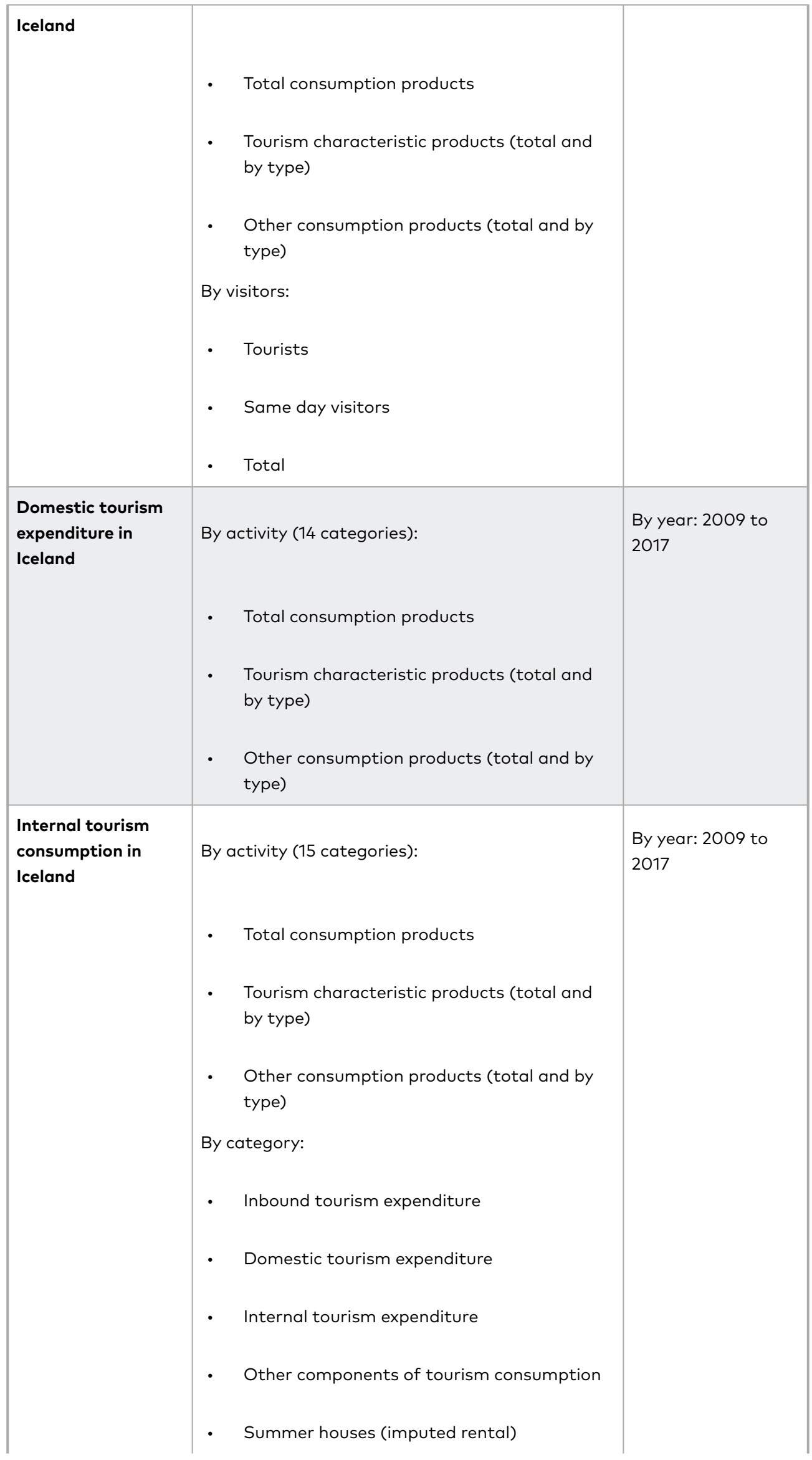




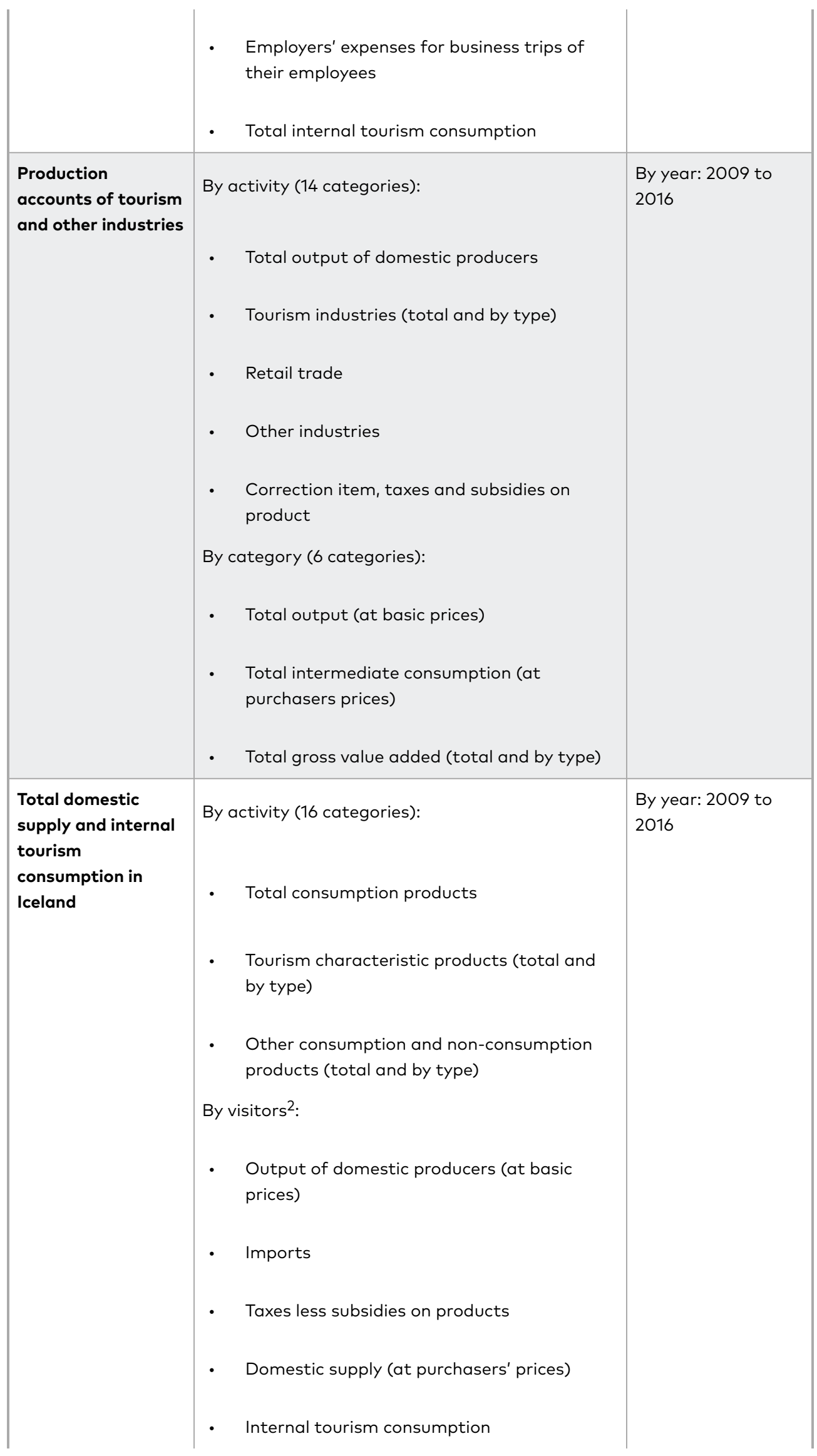




\begin{tabular}{|c|c|c|}
\hline & $\begin{array}{l}\text { - Tourism ratio (\%) } \\
\text { - Gross value added of the related industry (at } \\
\text { basic prices) } \\
\text { - Tourism gross value added (at basic prices) } \\
\text { - Tourism taxes less subsidies }\end{array}$ & \\
\hline $\begin{array}{l}\text { Number of trips and } \\
\text { overnight by forms } \\
\text { of tourism and } \\
\text { classes of visitors }\end{array}$ & $\begin{array}{l}\text { By activity: } \\
\text { - Number of trips } \\
\text { By type of tourism: } \\
\text { - Inbound tourism } \\
\text { Domestic tourism } \\
\text { By type of visitors: } \\
\text { - Visitors, total } \\
\text { - Tourists } \\
\text { - Excursionists (same-day visitors) }\end{array}$ & $\begin{array}{l}\text { By year: } 2009 \text { to } \\
2017\end{array}$ \\
\hline $\begin{array}{l}\text { International } \\
\text { arrivals by modes of } \\
\text { transport }\end{array}$ & $\begin{array}{l}\text { By transport (7 categories): } \\
\text { - Total } \\
\text { - Air (total and by type) } \\
\text { - Waterway (total and by type) }\end{array}$ & $\begin{array}{l}\text { By year: } 2009 \text { to } \\
2017\end{array}$ \\
\hline $\begin{array}{l}\text { Number of } \\
\text { establishment and } \\
\text { capacity by types of } \\
\text { accommodation }\end{array}$ & $\begin{array}{l}\text { By accommodation: } \\
\text { - Short term accommodation activities } \\
\text { - Camping sites } \\
\text { - Vacation homes (summer houses) } \\
\text { By establishment: }\end{array}$ & $\begin{array}{l}\text { By year: } 2009 \text { to } \\
2017\end{array}$ \\
\hline
\end{tabular}




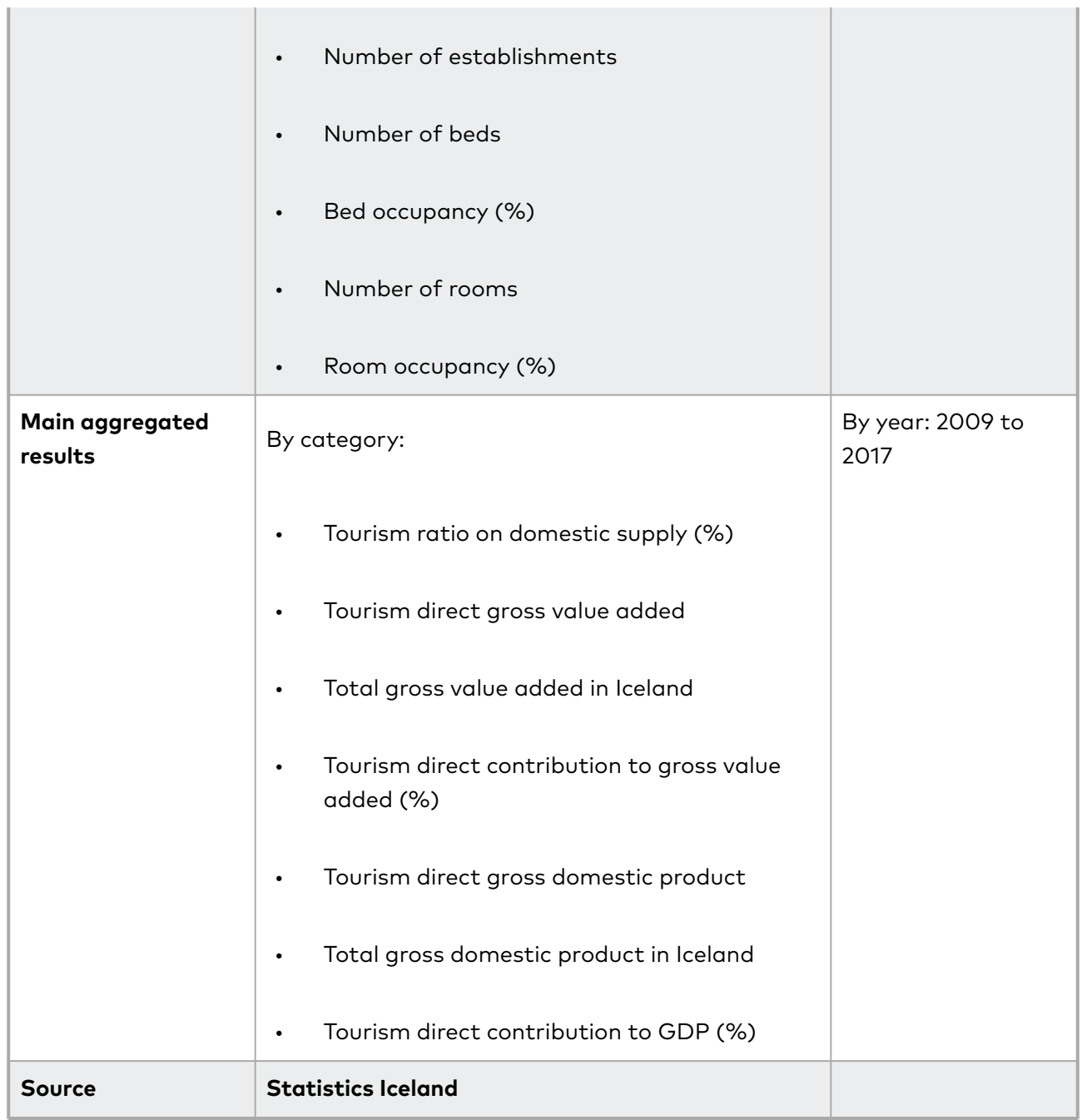

1 Tables on the tourism industry for earlier reference periods are also available in the section ,Tourist industry - earlier tables', but they were not listed here. The older set of TSAs is not fully comparable to the TSAs described here (Frenț 2015).

2 This category title is stated in the database but seems to be a misnomer.

Table 13. Tourism Satellite Accounts

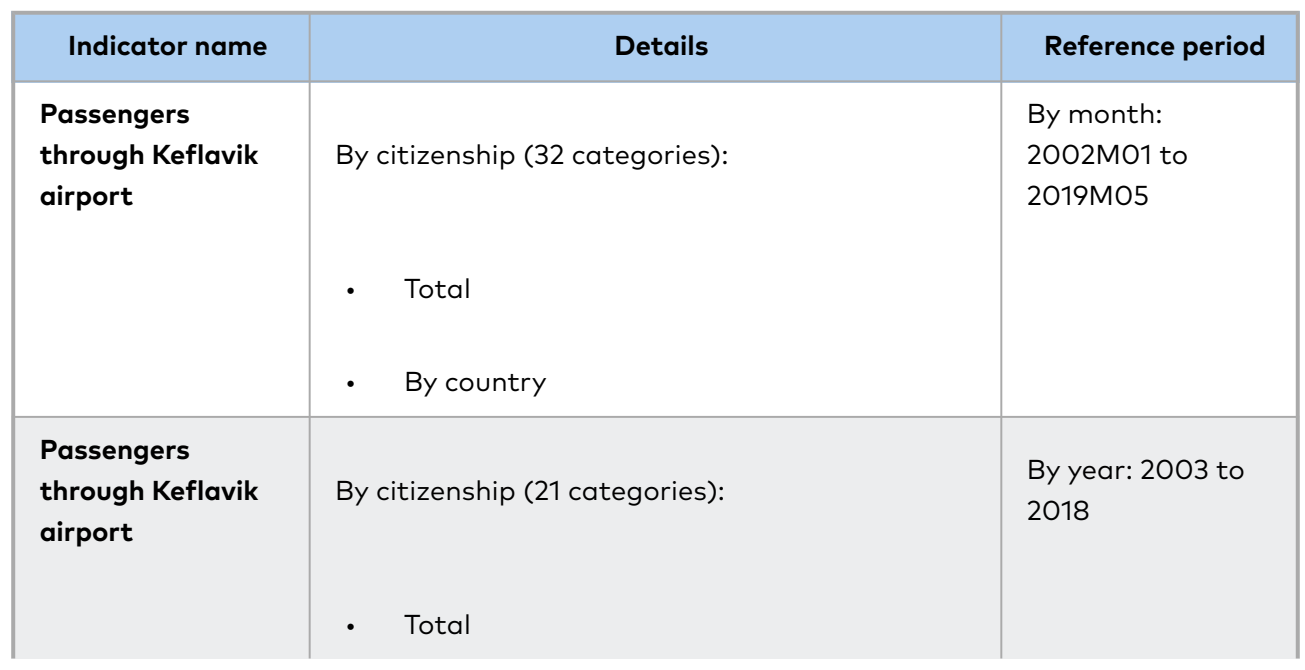




\begin{tabular}{|c|c|c|}
\hline & - By country & \\
\hline $\begin{array}{l}\text { Rental cars by } \\
\text { registration and } \\
\text { month }\end{array}$ & $\begin{array}{l}\text { By registration } \\
\text { - Listed } \\
\text { - Unlisted } \\
\text { - Total } \\
\text { - Applications for registrations }\end{array}$ & $\begin{array}{l}\text { By month: } \\
2010 \text { M07 to } \\
2019 \text { MO6 }\end{array}$ \\
\hline $\begin{array}{l}\text { VAT turnover in } \\
\text { activities related } \\
\text { to tourism }\end{array}$ & $\begin{array}{l}\text { By period/month (six categories) } \\
\text { By turnover/change (two categories) } \\
\text { By activity: } \\
\text { - Total turnover in activities related to } \\
\text { tourism } \\
\text { Passenger air transport } \\
\text { - Accommodation } \\
\text { - Food and beverage service activities } \\
\text { Renting and leasing of cars and light motor } \\
\text { vehicles } \\
\text { - Travel agencies } \\
\text { Passenger land transport }\end{array}$ & $\begin{array}{l}\text { By year: } 2016 \text { to } \\
2019\end{array}$ \\
\hline $\begin{array}{l}\text { Number of } \\
\text { employees in } \\
\text { activities related } \\
\text { to tourism }\end{array}$ & $\begin{array}{l}\text { By number of employees/change (two } \\
\text { categories) } \\
\text { By activity: } \\
\text { - Total } \\
\text { - Passenger air transport } \\
\text { - Accommodation } \\
\text { - Food and beverage service activities }\end{array}$ & $\begin{array}{l}\text { By month: } \\
2008 \mathrm{MO} 1 \text { to } \\
2019 \mathrm{MO} 3\end{array}$ \\
\hline
\end{tabular}


- Travel agency, tour operator and other reservation service and related activities

- Other activities linked to tourism

Table 14. Short term indicators in tourism

\begin{tabular}{|c|c|c|}
\hline Questions & Details on answer options results & Reference period \\
\hline $\begin{array}{l}\text { Did you visit any of } \\
\text { the following } \\
\text { sites/regions? }\end{array}$ & $\begin{array}{l}\text { - Nine types of regions and additional } \\
\text { number of sites } \\
\text { Answer categories available by gender, age, } \\
\text { profession, household income, market area, } \\
\text { nationality, transportation, type of trip, } \\
\text { purpose of visit and educational level of } \\
\text { respondents }\end{array}$ & Summer 2016 \\
\hline $\begin{array}{l}\text { Did you find the } \\
\text { number of visitors } \\
\text { too many or too } \\
\text { few (in selected } \\
\text { municipalities)? }\end{array}$ & $\begin{array}{l}\text { - Answer options: Too many/rather many/ } \\
\text { acceptable/rather few/too few } \\
\text { - Selected sites/municipalities } \\
\text { - Answer categories available by gender, age, } \\
\text { profession, household income, market area, } \\
\text { nationality, transportation, type of trip, } \\
\text { purpose of visit and educational level of } \\
\text { respondents }\end{array}$ & Summer 2016 \\
\hline $\begin{array}{l}\text { During your stay in } \\
\text { Iceland, in which of } \\
\text { these regions did } \\
\text { you stay over } \\
\text { night? }\end{array}$ & $\begin{array}{l}\text { - Nine types of regions } \\
\text { Answer categories available by gender, age, } \\
\text { profession, household income, market area, } \\
\text { nationality, transportation, type of trip, } \\
\text { purpose of visit and educational level of } \\
\text { respondents }\end{array}$ & Summer 2016 \\
\hline $\begin{array}{l}\text { Total length of } \\
\text { your stay in } \mathbf{x x x} \\
\text { (each region)? }\end{array}$ & $\begin{array}{l}\text { Nine types of regions } \\
\text { Answer categories available by gender, age, } \\
\text { profession, household income, market area, } \\
\text { nationality, transportation, type of trip, purpose } \\
\text { of visit and educational level of respondents }\end{array}$ & Summer 2016 \\
\hline Source & Icelandic Tourist Board & \\
\hline
\end{tabular}

Table 15. International Visitors in Iceland - Summer 2016 
Norway

\begin{tabular}{|c|c|c|}
\hline Indicator name & Details & Reference period \\
\hline $\begin{array}{l}\text { Accommodation } \\
\text { establishments, } \\
\text { total }\end{array}$ & $\begin{array}{l}\text { Two datasets on } \\
\text { - Guest nights, by guests' country of } \\
\text { residence (available at regional level) } \\
\text { - Guest nights, by type of accommodation } \\
\text { and guests' country of residence }\end{array}$ & $\begin{array}{l}\text { By months: } \\
2005 \mathrm{MO} 1 \text { to } \\
2019 \mathrm{MO} 4 \\
2010 \mathrm{MO1} \text { to } \\
2019 \mathrm{MO} 4\end{array}$ \\
\hline $\begin{array}{l}\text { Hotels and similar } \\
\text { establishments }\end{array}$ & $\begin{array}{l}\text { Ten datasets (all available at regional level) on } \\
\text { - Open establishments, beds and rooms } \\
\text { - Open establishments, beds and rooms } \\
\text { - } \text { Arrivals, by guests' country of residence } \\
\text { - Guest nights, by guests' country of } \\
\text { residence } \\
\text { Guest nights, by purpose of the } \\
\text { accommodation } \\
\text { - Occupied rooms } \\
\text { - } \text { Stilisation and price per room, so far this } \\
\text { year } \\
\text { Utilisation and sales/price per room }\end{array}$ & $\begin{array}{l}\text { By months: } \\
\text { 1985MO1 to } \\
2019 \mathrm{MO} 4 \\
1985 \text { to } 2018 \\
1985 \mathrm{MO} \text { to } \\
2019 \mathrm{MO} 4 \\
1985 \mathrm{MO} \text { to } \\
2019 \mathrm{MO} 4 \\
1986 \mathrm{MO} 1 \text { to } \\
2019 \mathrm{MO} 4 \\
1985 \mathrm{MO} 1 \text { to } \\
2019 \mathrm{MO} 4 \\
1992 \mathrm{MO} 1 \text { to } \\
2019 \mathrm{MO} 4 \\
1985 \mathrm{MO} 1 \text { to } \\
2019 \mathrm{MO} 4 \\
1992 \mathrm{MO} 1 \text { to } \\
2019 \mathrm{MO} 4 \\
1986 \mathrm{MO} 1 \text { to } \\
2019 \mathrm{MO} 4\end{array}$ \\
\hline Camping sites & $\begin{array}{l}\text { Five datasets (all available at regional level) on } \\
\text { - Capacity (camping sites, huts/rooms) } \\
\text { - Capacity, by type of capacity } \\
\text { - Guest nights, by guests' country of } \\
\text { residence }\end{array}$ & $\begin{array}{l}1998 \mathrm{MO} 1 \text { to } \\
2019 \mathrm{MO} 4 \\
1998 \text { to } 2018 \\
2005 \mathrm{MO} 1 \text { to } \\
2019 \mathrm{MO} 4\end{array}$ \\
\hline
\end{tabular}




\begin{tabular}{|c|c|c|}
\hline & $\begin{array}{l}\text { - Guest nights, by type of accommodation } \\
\text { - Seasonal contracts }\end{array}$ & $\begin{array}{l}2005 \mathrm{MO} 1 \text { to } \\
2019 \mathrm{MO} 4 \\
2005 \mathrm{MO} 1 \text { to } \\
2019 \mathrm{MO} 4\end{array}$ \\
\hline Holiday dwellings & $\begin{array}{l}\text { Three datasets (all available at regional level) on } \\
\text { - Capacity } \\
\text { - Capacity } \\
\text { - Guest nights, by guests' country of } \\
\text { residence }\end{array}$ & $\begin{array}{l}\text { 1998MO1 to } \\
2019 \mathrm{MO} 4 \\
1998 \text { to } 2018 \\
2009 \mathrm{MO} 1 \text { to } \\
2019 \mathrm{MO} 4\end{array}$ \\
\hline Hostels & Guest nights, by guests' country of residence & $\begin{array}{l}1999 \mathrm{MO} 1 \text { to } \\
2019 \mathrm{MO} 4\end{array}$ \\
\hline Source & Statistics Norway & \\
\hline
\end{tabular}

Table 16. Accommodation

\begin{tabular}{|c|c|c|}
\hline Indicator name & Details & Reference period \\
\hline $\begin{array}{l}\text { Hotels and } \\
\text { restaurants }\end{array}$ & $\begin{array}{l}\text { - By principal figures (8 categories) } \\
\text { - By industry division ( } 2 \text { and } 7 \text { categories) } \\
\text { - By region (20 counties) }\end{array}$ & $\begin{array}{l}\text { By year: } 2007 \text { to } \\
2017\end{array}$ \\
\hline $\begin{array}{l}\text { Accommodation } \\
\text { and food service } \\
\text { activities }\end{array}$ & $\begin{array}{l}\text { Principal figures, by industry subclass. Local kind- } \\
\text { of-activity units } \\
\text { Principal figures, by industry subclass. } \\
\text { Enterprises } \\
\text { Principal figures, by industry group (by region). } \\
\text { Local kind-of-activity units } \\
\text { Principal figures, by industry group and number } \\
\text { of persons employed. Local kind-of-activity units } \\
\text { Principal figures, by industry group and number } \\
\text { of persons employed. Enterprises } \\
\text { Investments, by category and industry subclass. } \\
\text { Enterprises } \\
\text { Investments, by group of fixed assets and } \\
\text { industry subclass. Enterprises } \\
\text { Principal figures, by industry division. Local kind- } \\
\text { of-activity units } \\
\text { Principal figures, by industry group. Preliminary } \\
\text { figures }\end{array}$ & $\begin{array}{l}2007 \text { to } 2017 \\
2007 \text { to } 2017 \\
2007 \text { to } 2017 \\
2007 \text { to } 2017 \\
2007 \text { to } 2017 \\
2007 \text { to } 2017 \\
2007 \text { to } 2017 \\
2007 \text { to } 2017 \\
2007 \text { to } 2017\end{array}$ \\
\hline
\end{tabular}




\begin{tabular}{|l|l|l|}
\hline $\begin{array}{l}\text { Structural business } \\
\text { statistics }\end{array}$ & $\begin{array}{l}\text { Principal figures for all enterprises, by } \\
\text { industry division }\end{array}$ & 2010 to 2017 \\
\hline Source & $\begin{array}{l}\text { Principal figures for local kind-of-activity } \\
\text { units, by industry division }\end{array}$ & 2010 to 2017 \\
\hline
\end{tabular}

Table 17. Accommodation and food service activities, structural business statistics

\begin{tabular}{|c|c|c|}
\hline Indicator name & Details & Reference period \\
\hline $\begin{array}{l}\text { Main indicators for } \\
\text { tourism industries } \\
\text { (NOK million) }\end{array}$ & $\begin{array}{l}\text { By contents: } \\
\text { - Current prices } \\
\text { - Constant } 2016 \text { prices } \\
\text { By main indicators: } \\
\text { - Output, basic prices } \\
\text { - Value added, basic prices } \\
\text { - Gross fixed capital formation } \\
\text { By tourism industry (11 categories) }\end{array}$ & $\begin{array}{l}\text { By year: } 2011 \text { to } \\
2018\end{array}$ \\
\hline $\begin{array}{l}\text { Output of tourism } \\
\text { characteristic } \\
\text { products (basic } \\
\text { prices, NOK } \\
\text { million) }\end{array}$ & $\begin{array}{l}\text { By contents: } \\
\text { - Current prices } \\
\text { - Constant } 2016 \text { prices } \\
\text { By tourism characteristic product (11 categories) }\end{array}$ & $\begin{array}{l}\text { By year: } 2011 \text { to } \\
2018\end{array}$ \\
\hline $\begin{array}{l}\text { Employment in } \\
\text { tourism industries }\end{array}$ & By tourism industry (11 categories) & $\begin{array}{l}\text { By year: } 2011 \text { to } \\
2018\end{array}$ \\
\hline $\begin{array}{l}\text { Tourism } \\
\text { consumption in } \\
\text { Norway, by } \\
\text { consumer group } \\
\text { and tourism } \\
\text { industry (NOK } \\
\text { million) }\end{array}$ & $\begin{array}{l}\text { By contents: } \\
\text { - Current prices } \\
\text { - Constant } 2016 \text { prices } \\
\text { By consumer group: } \\
\text { - Total tourism consumption }\end{array}$ & $\begin{array}{l}\text { By year: } 2007 \text { to } \\
2018\end{array}$ \\
\hline
\end{tabular}




\begin{tabular}{|c|c|c|}
\hline & $\begin{array}{l}\text { - Tourism consumption in Norway by non- } \\
\text { residents } \\
\text { - Tourism consumption in Norway by resident } \\
\text { households } \\
\text { - Tourism consumption in Norway by resident } \\
\text { industries } \\
\text { By tourism industry (13 categories) }\end{array}$ & \\
\hline $\begin{array}{l}\text { Main indicators for } \\
\text { tourism industries } \\
\text { (NOK million) (C) }\end{array}$ & $\begin{array}{l}\text { By region ( } 21 \text { counties) } \\
\text { By main indicator: } \\
\text { - Value added, basic prices } \\
\text { - Output, basic prices } \\
\text { By tourism industry: } \\
\text { - Tourism industries in total } \\
\text { - Accommodation and food service activities } \\
\text { - Transport } \\
\text { - Culture and entertainment }\end{array}$ & $\begin{array}{l}\text { By year: } 2011 \text { to } \\
2018\end{array}$ \\
\hline $\begin{array}{l}\text { Employment in } \\
\text { tourism industries } \\
\text { (C) }\end{array}$ & $\begin{array}{l}\text { By region ( } 21 \text { counties) } \\
\text { By tourism industry: } \\
\text { - Tourism industries in total } \\
\text { - Accommodation and food service activities } \\
\text { - Transport } \\
\text { - Culture and entertainment }\end{array}$ & $\begin{array}{l}\text { By year: } 2011 \text { to } \\
2018\end{array}$ \\
\hline Source & Statistics Norway & \\
\hline
\end{tabular}

Tbale 18. Tourism satellite accounts 


\section{Greenland}

\begin{tabular}{|c|c|c|}
\hline Indicator name & Details & Reference period \\
\hline Overnight stays & $\begin{array}{l}\text { - } \text { By month } \\
\text { - By nationality (17 categories) } \\
\text { - By region } \\
\text { - By unit (number of overnight stays/number } \\
\text { of guests/average overnight stays per } \\
\text { guest) }\end{array}$ & $\begin{array}{l}\text { By year: } 1994 \text { to } \\
2019\end{array}$ \\
\hline $\begin{array}{l}\text { Rented rooms and } \\
\text { room capacity }\end{array}$ & $\begin{array}{l}\text { - By month } \\
\text { - By region } \\
\text { - By unit (rented rooms/room capacity/ } \\
\text { percent) }\end{array}$ & $\begin{array}{l}\text { By year: } 1996 \text { to } \\
2019\end{array}$ \\
\hline Source & Statistics Greenland & \\
\hline
\end{tabular}

Table 19. Overnight stays

\begin{tabular}{|c|c|c|}
\hline Indicator name & Details & Reference period \\
\hline $\begin{array}{l}\text { Number of cruise } \\
\text { passengers for } \\
\text { each harbour }\end{array}$ & $\begin{array}{l}\text { - } \quad \text { By month } \\
\text { - By port (20 categories) }\end{array}$ & $\begin{array}{l}\text { By year: } 2015 \text { to } \\
2017\end{array}$ \\
\hline $\begin{array}{l}\text { Number of cruises } \\
\text { by passenger } \\
\text { capacity }\end{array}$ & $\begin{array}{l}\text { - } \quad \text { By month } \\
\text { - } \quad \text { By capacity (5 categories) }\end{array}$ & $\begin{array}{l}\text { By year: } 2015 \text { to } \\
2017\end{array}$ \\
\hline $\begin{array}{l}\text { Nationality of } \\
\text { cruise ship } \\
\text { passengers }\end{array}$ & $\begin{array}{l}\text { - } \quad \text { By month } \\
\text { - } \quad \text { By country (36 category) }\end{array}$ & $\begin{array}{l}\text { By year: } 2015 \text { to } \\
2017\end{array}$ \\
\hline $\begin{array}{l}\text { Number of cruise } \\
\text { passengers by } \\
\text { month }\end{array}$ & - By month & $\begin{array}{l}\text { By year: } 2003 \text { to } \\
2017\end{array}$ \\
\hline Source & Statistics Greenland & \\
\hline
\end{tabular}

Table 20. Cruises 


\begin{tabular}{|l|c|l|}
\hline \multicolumn{1}{|c|}{ Indicator name } & \multicolumn{1}{|c|}{ Details } & \multicolumn{1}{|c|}{ Reference period } \\
\hline $\begin{array}{l}\text { Passengers } \\
\text { travelling from } \\
\text { Greenland }\end{array}$ & $\begin{array}{l}\text { By airport (7 categories) } \\
\text { By location/country of residence (20 } \\
\text { categories) }\end{array}$ & $\begin{array}{l}\text { By year: 2008 to } \\
2019\end{array}$ \\
\hline $\begin{array}{l}\text { Number of } \\
\text { international } \\
\text { passengers by } \\
\text { time, airport and } \\
\text { month }\end{array}$ & $\begin{array}{l}\text { By month } \\
\text { By month }\end{array}$ & By year: 2001 to \\
\hline Source & Statistics Greenland & 2019 \\
\hline
\end{tabular}

Table 21. Flight passengers

\section{Åland}

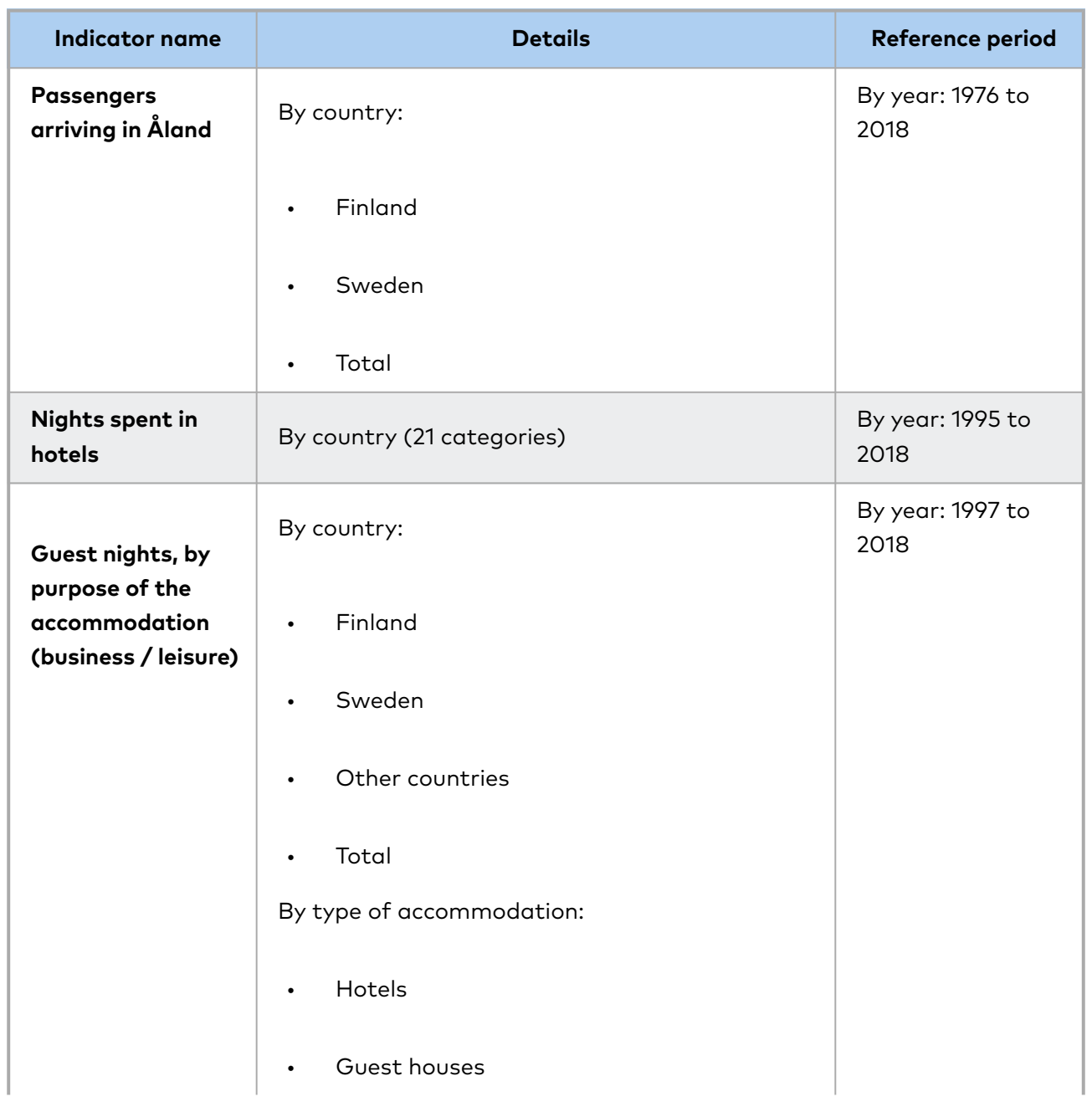




\begin{tabular}{|l|l|l|} 
& $\cdot$ Cottages \\
& $\cdot$ Camping \\
& $\cdot \quad$ Total \\
\hline Source & Statistics and Research Åland \\
\hline
\end{tabular}

Table 22. Tourism 


\title{
About this publication
}

\section{Regional Tourism Satellite Accounts for the Nordic Countries}

\author{
Authors: Anna Karlsdóttir and Nora Sánchez Gassen \\ Contributors: Jie Zhang, Jouko Kinnunen and Katarina Fellman
}

This publicaiton is a cooperation between Nordregio, the Statistics and Research Åland (ÅSUB) and the Centre for Regional and Tourism

Research (CRT).

Nordregio Report 2021:2

ISBN: 978-91-8001-010-8

ISSN: $1403-2503$

DOI: http://doi.org/10.6027/R2021:2.1403-2503

(C) Nordregio 2021

Cover photo: Maria Michelle, Pixabay

Layout: Marija Zelenkauskè, Nordregio 


\section{III) Nordregio}

P.O. Box 1658

SE-111 86 Stockholm, Sweden

nordregio@nordregio.org

www.nordregio.org

www.norden.org

ISBN: 978-91-8001-010-8

ISSN: 1403-2503

DOI: http://doi.org/10.6027/R2021:2.1403-2503 